\title{
unesp
}

\author{
$\underset{f a n c}{ }$ \\ Universidade Estadual Paulista \\ "Júlio de Mesquita Filho" \\ Faculdade de Arquitetura, \\ Artes e Comunicação
}

Dissertação de mestrado

\section{O desenho de expressão no processo de projetos em comunicação visual}

Luís Renato do Nascimento

\section{()eign}

Programa de Pós-Graduação em Design

Área de concentração: Desenho do Produto

Linha de Pesquisa: Planejamento do Produto

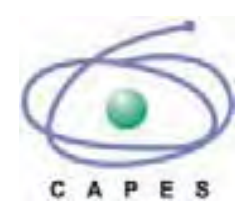

Pesquisa financiada pela CAPES - Coordenação de Aperfeiçoamento de Pessoal de Nível Superior. 


\title{
unesp
}

\author{
fanc \\ Universidade Estadual Paulista \\ "Júlio de Mesquita Filho" \\ Faculdade de Arquitetura, \\ Artes e Comunicação
}

Dissertação de mestrado

\section{O desenho de expressão no processo de projetos em comunicação visual}

\section{(jeign}

Programa de Pós-Graduação em Design

Área de concentração: Desenho do Produto

Linha de Pesquisa: Planejamento do Produto

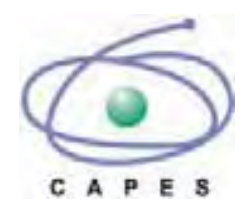

Pesquisa financiada pela CAPES - Coordenação de Aperfeiçoamento de Pessoal de Nível Superior.
Luís Renato do Nascimento

Profa. Dra. Aniceh Farah Neves - orientadora

Dissertação apresentada ao Programa de Pós-Graduação em Design, área de concentração em Desenho do Produto, linha de pesquisa em Planejamento do Produto da Faculdade de Arquitetura, Artes e Comunicação da Universidade Estadual Paulista "Júlio de mesquita Filho" - campus de Bauru; como requisito à obtenção do título de Mestre em Design. 
Nascimento, Luis Renato do.

O desenho de expressåo no processo de projetos em comunicaçăo visual / Luis Renato do Nascimento, 2010.

100 folhas.: il.

Orientador: Aniceh Farah Neves.

Dissertação (Mestrado) - Universidade Estadual Paulista. Faculdade de Arquitetura, Artes e Comunicaçăo, Bauru, 2010.

1. Esboço. 2. Rascunho. 3. Desenho. 4. Projeto. Universidade Estadual Paulista. Faculdade de Arquitetura, Artes e Comunicação. II-Título. 
Banca de avaliação

Titulares

Profa. Dra. Aniceh Farah Neves - orientadora PPGDesign - FAAC - UNESP

Prof. Dr. Olympio José Pinheiro PPGDesign - FAAC - UNESP

Profa. Dra. Ligia Maria Sampaio de Medeiros Gomes Universidade Ritter dos Reis - UniRitter

Suplentes

Prof. Dr. Milton Koji Nakata

FAAC-UNESP

Prof. Dr. Luiz Vidal de Negreiros Gomes

Universidade Ritter dos Reis - UniRitter 


\section{Agradecimentos}

Aos meus pais, Vera e Roberto,

que me ensinaram os principais valores da vida e em especial à minha mãe que ajudou

a cuidar da Sofia nesta fase tão especial

e ao meu pai que contribuiu imensamente

com sua co-orientação

à Aniceh, pela orientação e paciência

à Ligia Medeiros, pela contribuição no tema dessa pesquisa;

aos coordenadores do Programa de PósGraduação e à CAPES, pela concessão da

Bolsa de Estudos, imprescindível para a qualidade dessa pesquisa

à todas as pessoas que contribuíram direta

ou indiretamente para que esse sonho se tornasse realidade e principalmente, à DEUS. 


\section{Dedicatória}

Dedico este trabalho à minha mulher Giselli e à minha filha Sofia 
Resumo

\section{O desenho de expressão no processo de projetos em comunicação visual}

O modo como o homem desenvolve seus objetos sofreu uma profunda transformação ao longo de sua história, passando da produção artesanal à produção industrial no final do séc. XVIII, dando origem ao projeto industrial, e assim, ao design. Surge com isso a necessidade de metodologias de trabalho que organizem o processo, orientando assim a criação. A partir do final do séc. XX uma nova transformação ocorre, com a inserção da informática nesse processo, modificando as possibilidades de manipulação do projeto. Com a evolução tecnológica ocorrem também transformações culturais. Atualmente existe uma valorização de "resultados imediatos", reflexo de uma sociedade ansiosa, que acaba menosprezando o valor dos processos de forma geral. Assim, técnicas tradicionais de projetação são muitas vezes substituídas ou ignoradas diante das novas tecnologias.
Além desse problema de adequação aos processos tradicionais, existe uma imprecisão de linguagem para designar os tipos de desenhos utilizados nesse processo, o que acaba dificultando seu entendimento e consequentemente a própria prática. Para essa pesquisa optou-se pelo termo desenho expressional como forma de abranger os termos esboço, rascunho, croqui, rafe, sketch e esquete. De modo geral, são recursos tradicionais que são sub-utilizados no processo criativo. Através de entrevistas com os alunos do $5^{\circ}$ e $6^{\circ}$ termo do Curso de Graduação em Desenho Industrial da Faculdade de Arquitetura, Artes e Comunicação, da Universidade Estadual Paulista “Julio de Mesquita Filho", campus de Bauru/SP, procurou-se identificar como esse recurso - o desenho expressional - vem sendo visto e utilizado e qual a sua importância no processo de projeto.

Palavras-chave: esboço, rascunho, croqui, desenho, projeto. 
Abstract

\section{Expressional drawing on the process of visual communication projects}

The way like man develop the goals had a huge change along the history, starting with the handmade production until the industrial production in the 18th century, originating the industrial project and also the design. Based on this, begins the necessity of methodologies of work that organize the process and guide the creation. From the end of 20th century, a news transformation happened: insertion of computing in all this process, changing the possibilities of project handling. Due to technologic evolution some cultural transformations have occurred also. Nowadays there is an appreciation of "direct results", reflection of an anxious society that in general despises the values of processes. Thereby, traditional techniques of project are just ignored or replaced by news technologies over and over. Besides this problem of traditional methods adjustment, there is a language inaccuracy to assign the kinds of drawings used in this process, that difficult comprehension and practice. For this research, the term "expressional drawing" was chosen to include another terms: sketch, draft, croquet and rough draft. Generally, these are traditional resources sub used during the creative process. Some interviews were made with students of 5th and 6th semesters of Design graduation course, from Architecture, Arts and Communication College, "Julio de Mesquita Filho" University, Bauru campus, Sao Paulo state. Based on this interviews, it was possible to indentify how this resource - expressional drawing - has been used and seen and how much important is this during the process of project.

Key-words: sketch, draft, croquet, drawing, project. 
Banca de avaliação ....................................................................... II

Agradecimentos ................................................................. III

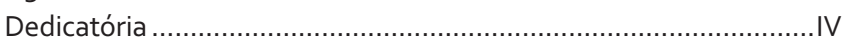

Resumo

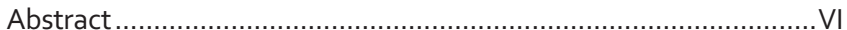

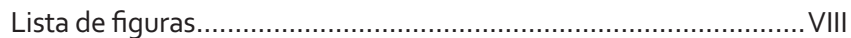

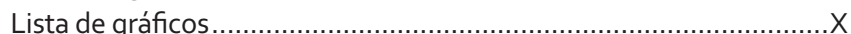

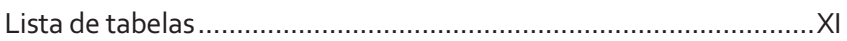

Bibliografia consultada e referenciada.......

\section{Apêndices}

Apêndice A - Formulário de pesquisa

\section{Anexos}

Anexo A - Programa da disciplina Projeto $5-P V$

Anexo B - Programa da disciplina Projeto 5 - PP

Anexo C - Programa da disciplina Projeto 6 - PV ....

.90

Anexo D - Programa da disciplina Projeto 5 - PP....

.92

Anexo E-Processo de concepção MAC-Niterói/RJ

93

Anexo F-Pixar Process
Introdução ……............................................................

\section{Capítulo 1: O processo de projeto}

Nascimento do projeto .............................................................

Metodologia e criatividade no processo....................................... 11

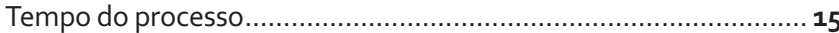

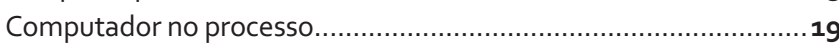

Capítulo 2: O desenho no processo de projetos

Desenho no processo................................................................. 25

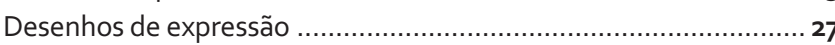

Desenho expressional e suas transformações................................... 32

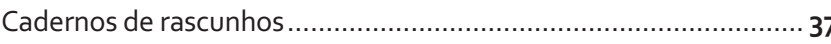

Desenho expressional e organização de ideias ................................ 41

Desenho expressional e projetos .............................................. 46

\section{Capítulo 3: Pesquisa de campo}

Procedimentos da pesquisa ......................................................5

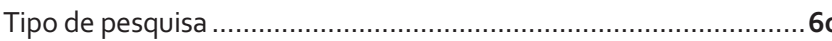

Métodos

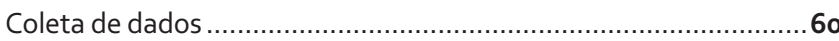

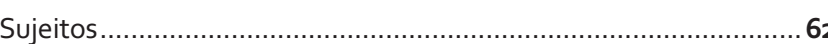

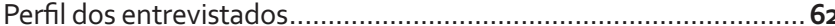

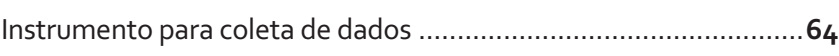

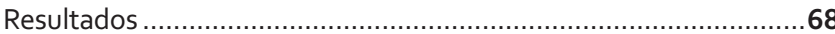

Considerações finais .......................................................... 77 


\section{Lista de figuras}

Figura 1. Produto feito à mão com função principalmente prática. Jarra de latão, Lübeck, cerca de 1780. Coleção Dexel - Braunschweig. Fonte: Löbach

(2001, p.37).

Figura 2. Produto feito à mão com função principalmente simbólica. Simbolização de status. Jarra de prata Augsburgo, cerca de 1745. Fonte: Löbach (2001, p.37).......8

Figura 3. Revolução Industrial: ilustração de 1841 demonstrando um mecanismo de automação do torno, transformando o trabalhador em simples operador. Fonte: (CARDOSO, 2008, p.34)....

Figura 4. Frontispício da edição de News From Nowhere: exemplo raro da atuação de Morris como autor exemplo raro da atuação de Moris comoautor, $(2008$, p.83) ...

Figura 5. Cadeira fabricada pela Morris \& Co., de William Morris, a partir da década de 1860. Fonte: Cardoso

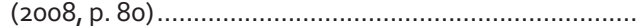

Figura 6. Integração de modelos das habilidades mentais, manuais e expressionais gráficas. Fonte: Gomes et. al. $(2009$, p.371).....

Figura 7. Uma das críticas mais conhecidas sobre, entre outras coisas, o acelerado processo de produção industrial: Tempos Modernos, de Charlie Chaplin (EUA, 1936). Fonte: WEBL1237.JPG (s.d.)

Figura 8. Discussão da animação Toy Story auxiliada pelos desenhos de expressão. Fonte: The Pixar (2007)

Figura 9. "A Adoração dos Magos": obra incompleta, à óleo sobre madeira, de Leonardo da Vinci, 1481. Fonte: Zöllner (2006, p.25)

Figura 10. "A Adoração dos Magos" para Gaspare Del Lama (cerca de 1472-1475), de Sandro Botticelli: obra que pode ter inspirado Leonardo da Vinci em sua "A Adoração dos Magos", de 1481. Fonte: Zöllner (2006, p.24)..
Figura 11. Estudo de composição à pena e tinta sobre ponta metálica para "A Adoração dos Magos", de Leonardo da Vinci, 1481. Fonte: ZOLLNER (2006, p. 26)

Figura 12. Estudo de composição em perspectiva cônica, à pena e tinta sobre ponta metálica, para o plano de fundo de "A Adoração dos Magos", de Leonardo da Vinci, 1481. "A Adoração dos Magos", de Leonardo da Vinci, 1481.

Figura 13. Estudo de Warren Louw para revista IMAGINE FX n 49. Fonte: Louw (2009a).

Figura 14. Estudo final de Warren Louw para revista IMAGINE FX no 49: mudança de enfoque, neste caso o ângulo de visão. Fonte: Louw (200gb)

Figura 15. Arte final de Warren Louw para a revista IMAGINE FX no 49. Fonte: Louw (2009c).

Figura 16. A Áltima Ceia, à óleo e têmpera sobre gesso, de Leonardo da Vinci (cerca de 1495-1498). Fonte: Zöllner (2006, p. 53)

Figura 17. Primeiro estudo para A Última Ceia, à pena e tinta de Leonardo da Vinci (cerca de 1495). Fonte: Zöllne (2006, p. 50)

Figura 18. Estudo para A Última Ceia (Judas), à sanguina sobre papel avermelhado, de Leonardo da Vinci (cerca de 1495). Fonte: Zöllner (2006, p. 56)

Figura 19. Estudo para $A$ Última Ceia (S. Filipe), à giz preto, de Leonardo da Vinci (cerca de 1495). Fonte: Zöllner (2006, p. 57) ...

Figura 20. Estudo para A Última Ceia [Pedro?], à giz preto, de Leonardo da Vinci (cerca de 1495). Fonte: Zöllne (2006, p. 58).

Figura 21. Anotações de anatomia sobre "O Feto no Útero", de Leonardo da Vinci (cerca de 1510-1512). Pena e tinta com aguada sobre giz preto e vermelho. Fonte: Zöllner (2006, p.82) 


\section{Lista de figuras}

Figura 22. Página de livro de sketchbook do artista Francisco Herrera. Fonte: herrera2_ 04 big.jpg (s.d.).

Figura 23. Estudos em caderno de rascunhos do designer Rex Crowle. Fonte: Computer Arts (2009, p.51)

Figura 24. Desenhos do tipógrafo americano FrederickW. Goudy (1865-1947) para o tipo que leva o seu nome. Fonte: Haley (1992)

Figura 25. Desenhos de F. W. Goudy para o tipo 'University California Old Style' (1939). Fonte: Haley (1992) ............47

Figura 26. Estudos de Martin Majoor para a fonte Seria, Fonte: Lupton (2006)

Figura 27. Estudo de alternativas para logo "The Islands of the Bahamas". Apenas 3 estudos (no alto) executadas à mão livre e outros 6 estudos executados provavelmente no computador. Fonte:

Figura 28. Versão final da identidade criada para "The Islands of the Bahamas". Fonte: LogoLounge2, (s.d., p. 26) .......48

Figura 29. Estudos de Alexandre Wollner para a identidade das Fechaduras BR. Fonte: Wollner (2003, p. 263) ..................50

Figura 30. Arte final de Alexandre Wollner para a identidade das Fechaduras BR. Fonte: Wollner (2003, p. 267) ...........50

Figura 31. Estudos de Walter Crane para o livro The Bases of Design (As Bases do Design), 1898, evidenciando o planejamento de páginas duplas. Fonte: Meggs (2009, p. 226)......

Figura 32. Estudo de detalhes do designer Ron Costley para projeto gráfico de livro. Fonte: Hendel (2003, p.115) ......52

Figura 33. Estudos de configuração dos elementos na página do designer Ron Costley para projeto gráfico de livro. Fonte: Hendel (2003, p.116-117)
Figura 34. Desenho inicial executado à mão livre, para infográfico sobre acidente do avião AF447 para revista Época, Equipe de Arte da revista Época. Fonte: Vergotti (2009a).

54

Figura 35. Desenho (digital) mais detalhado/refinado da Equipe de Arte da revista Época sobre acidente do avião AF447 para infográfico da revista Época. Fonte: Vergotti (200gb)

Figura 36. Versão final do infográfico sobre acidente do avião AF447 para revista Época, Equipe de Arte da revista Época. Fonte: Vergotti (2009c)

Figura 37. Metodologia utilizada por Luli Radfahrer para concepção de sites baseada em 4 grandes fases. Fonte: Radfahrer (s.d., p. 149).

Figura 38. Storyboard (Peter Pan, 1953), onde se trabalham continuidade, ângulos de câmera, encenação, planificação, movimento, etc., Walt Disney Studio. ○ Disney Enterprises, Inc. Fonte: BARBOSA JÚNIOR (2002, p. 111).

Figura 39. Storyboard de Johnny Kelly: "mudar de quatro para doze painéis por página fez com que eu parasse de doze pain is desenhar frames muito elaborados eme ajudou (COMPUTER ARTS, 2009, p.49)...

Figura 40. Estudos de personagem evidenciando mudanças de enfoque bastante refinadas, provavelmente devido à fluência gráfica do criador. $O$ desenho a cores contempla a versão final.

Fonte: MACACOLÂNDIA (s.d.). ...

Figura 41. Modelo final do formulário de pesquisa. 


\section{Lista de gráficos}

Gráfico 1. Utilização do desenho expressional por número de alunos...........69

Gráfico 2. Uso do desenho de expressão separado por habilidade.................69

Gráfico 3. Quantidade de desenhos realizados por aluno. .............................70

Gráfico 4. Quantidade de desenhos desenvolvidos por aluno de acordo com as habilidades.

Gráfico 5. Dificuldade na criação com relação ao uso do desenho de

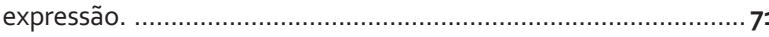

Gráfico 6. Dificuldade na criação em relação à habilidade no desenho à mão livre.

Gráfico 7. Dificuldade na criação em relação à habilidade na principal ferramenta utilizada. ………………………………………....... 72

Gráfico 8. Dificuldade na criação em relação à experiência no projeto........... 73

Gráfico 9. Utilização do desenho expressional em cada fase do

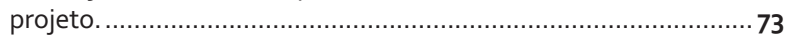

Gráfico 10. Utilização da metodologia entre as duas habilidades. ....................74

Gráfico 11. Utilização da metodologia no processo de projeto em relação ao total de alunos 


\section{Lista de tabelas}

Tabela 1. Total de alunos entrevistados

Tabela 2. Quantidade de desenhos de expressão realizados..........................71

Tabela 3. Principal fonte de pesquisa. 


\section{Introdução}




\section{Introdução}

O presente problema surgiu do contato, como professor substituto, com estudantes de design gráfico em disciplina projetual, e também da experiência como profissional em design gráfico de algumas agências de comunicação e propaganda.

Na primeira experiência, ao trabalhar com a criação de peças gráficas, pôde-se observar que muitos alunos se sentiam um pouco desorientados na fase de criação sem saber direito o que fazer. Já na fase de construção e desenvolvimento do projeto no computador, percebeu-se também que muitos ficavam parados diante da máquina sem saber muito como proceder, e grande parte deles não apresentavam domínio suficiente sobre o software utilizado. Na segunda experiência, através da prática profissional em agências de propaganda, pôde-se perceber que designers formados recentemente e alguns mais experientes, apresentavam bom domínio sobre os softwares utilizados e certa "segurança" ao iniciarem um projeto, começando a desenvolvêlos diretamente no computador. 
Em ambos os casos, observou-se que não se utilizavam de muita informação para começar o projeto: desenvolviam suas pesquisas quase que sempre através da internet, ignoravam briefings, nem faziam muitos estudos à mão livre no processo de projeto, quando o faziam e, mesmo aqueles que se dispuseram à sua prática, não conseguiam utilizá-lo de forma produtiva, sendo executado quase que simplesmente como "uma etapa banal" do processo. Percebeu-se que eles não conseguiam extrair conteúdos, informações ou reflexões que pudessem contribuir com o projeto.

O maior problema porém, estava na incidência muito grande de trabalhos em que o resultado final não atendia ao cliente ou à proposta, gerando necessidade de refazer algumas etapas, muitas vezes desde o início. Nas duas experiências, percebeu-se que havia uma ânsia muito grande por parte dos designers em começar a desenvolver os trabalhos no computador, ignorando informações sobre o projeto, pulando fases, enfim, não se utilizando muito da metodologia de projeto. Essas experiências suscitavam algumas inquietações a respeito da aplicação ou não dos métodos de projetação e da dificuldade de entender o problema e lidar com informações sobre o projeto, seja através dos briefings, de pesquisas, ou estudos à mão livre.
A partir dos levantamentos históricos realizados, percebeu-se que a necessidade de se desenvolver projeto foi, e ainda é, um dos elementos mais importantes que caracterizaram o surgimento do design, dando origem à várias metodologias como forma de dar base e direcionamento à criação dos projetos industriais. Apesar de suas limitações, essas metodologias apresentaram um grande avanço nos modos de criação dos produtos industriais.

De forma geral, a metodologia de projeto em design é um processo a ser percorrido em todo projeto como forma de se chegar a um resultado - o produto. Porém, uma crescente onda de valorização do tempo que tomou conta da população mundial - lucro fácil, sucesso rápido, resultado imediatos - parece agora refletir-se no processo de projeto: há aqueles que pulam fases, se recusam ou menosprezam (ou não entendem) sua utilização como forma de resolver problemas em design, reflexos de uma sociedade ansiosa, que se esqueceu de que resultados dependem de processos. Independente da metodologia adotada, o processo de projeto em design sempre fez uso de vários tipos de representações gráficas. 
Com a inserção da informática nesse processo, as possibilidades de manipulação das representações gráficas se alteraram profundamente, dando origem à novas tecnologias enquanto que técnicas tradicionais começaram a ser questionadas. No campo do design gráfico parece haver uma influência ainda maior das ferramentas gráficas digitais no processo, pois muitas das peças podem ser desenvolvidas do começo ao fim utilizando-se os recursos do computador, como é o caso de peças de fim digital: sites, bâneres e animações para internet. Porém, mesmo neste caso, alguns autores defendem o uso da "etapa do lápis" na concepção destes projetos.

No Brasil, ainda não há um consenso sobre o uso das terminologias adotadas para descrever os tipos de desenho que são utilizados em projeto. Existem aqueles desenhos mais expressivos, executados normalmente à mão livre, com lápis sobre papel, na fase de concepção, que são foco desta pesquisa. Existem tam bém aqueles desenhos mais precisos e refinados, realizados com auxilio de ferramental a fim de indicar instruções gráficas que serão interpretadas por outras pessoas ou máquinas.
Entre os termos utilizados para designar os desenhos expressivos no Brasil, nos vários tipos de projetos industriais, encontram-se: rascunho, esboço, croqui, rafe, rough, sketch, esquete. Termos que variam conforme a área de utilização, seja arquitetura, engenharia ou entre as diversas vertentes do design, porém mesmo nos principais dicionários da área, alguns termos não são contemplados. Diante dessa imprecisão de termos, e já que todos eles representam "intenções de projeto", o termo desenho expressional, sugerido por Medeiros (2004), é adotado nesta pesquisa como forma de representar todos esses "nomes" que este tipo de desenho tem.

Além dessa indefinição de termos em desenho, existem também divergências nas classificações das especialidades do design: design gráfico, web design, motion design, design de informação, design de superfície; contudo, todas essas especialidades se conjugam num mesmo patamar: a comunicação visual. Assim definiu-se como objeto desta pesquisa os desenhos de expressão utilizados em projetos de comunicação visual. 
A hipótese dessa pesquisa é de que o desenho-expressional seja uma ferramenta importante no processo de projeto e, mais importante ainda, no ensino desse processo onde, com raras exceções, o futuro profissional ainda não tem a experiência para desenvolver o projeto. Supõe-se que essa ferramenta possa contribuir para visualizar, entender e resolver melhor o problema do projeto, dando ordem e sentido à criação, tanto no mercado de trabalho, quanto, e principalmente, no ensino do design, além de tornar a produção mais eficiente, tanto em relação ao tempo empregado no projeto, quanto aos resultados obtidos com a conclusão do mesmo. Outra hipótese, avaliada através da pesquisa de campo, é de que o desenho-expressional seja um recurso muito útil, porém, pouco explorado nos cursos de graduação em comunicação visual, principalmente como forma de buscar saídas para facilitar o gerenciamento da atividade de desenvolvimento de projetos. Parte-se também da hipótese de que os alunos não conhecem, não usam, ou não estão entendendo o potencial, os conceitos e as possibilidades envolvidas com o uso deste tipo de desenho no processo de projeto.

O desenho-expressional é um tema bastante atual e vários autores já se dispuseram a estudá-lo, principalmente na área de arquitetura, onde se utiliza o termo croqui. Por isso alguns dos levantamentos apontados aqui, além dos resultados apresentados, podem servir também para áreas onde há essa equivalência de processo criativo apoiado na representação visual.
Os objetivos dessa pesquisa foram: verificar as implicações do desenho-expressional no processo projetual, realizada principalmente através de bibliografias e analisar, através de pesquisa de campo, como os alunos estão vendo e utilizando esse recurso no curso de graduação em desenho industrial da Faculdade de Arquitetura, Artes e Comunicação, da Universidade Estadual Paulista "Júlio de Mesquita Filho", campus de Bauru.

Essa pesquisa está estruturada da seguinte forma: o Capítulo 1 apresenta um panorama da evolução do design, ressaltando a valorização do projeto e a conseqüente desenvolvimento das metodologias projetuais para orientar o processo de projeto; o Capítulo 2 contempla as várias implicações relacionadas com o desenho-expressional; o Capítulo 3 apresenta os métodos, procedimentos e resultados da pesquisa de campo. 


\title{
Capítulo 1
}

\section{O processo de projeto}

\author{
Nascimento do projeto 7 \\ Metodologia e criatividade no processo 11 \\ Tempo do processo 15 \\ Computador no processo 19
}

"O processo é definido por fases distintas com pontos lógicos de início e finalização, o que facilita as tomadas de decisão nos intervalos apropriados. A eliminação de etapas ou reorganização

do projeto pode apresentar uma atraente forma de cortar custos e tempo, porém, isso pode acarretar riscos substanciais e impedir benefícios a longo prazo. O processo, quando feito corretamente, pode produzir resultados extraordinários" (WHEELER, 2008, p.80). 


\section{Nascimento do projeto}

"Todo processo de design é tanto um processo criativo como um processo de solução de problemas"

(LÖBACH, 2001, p.141)

A necessidade do homem de produzir objetos existe praticamente desde a pré-história. Para obter alimento, por exemplo, uma de suas necessidades mais básicas, ele descobriu que poderia conseguir maior êxito utilizando instrumentos de caça. A produção de ferramentas e utensílios também facilitava suas tarefas diárias, portanto, a necessidade de produzir objetos estava vinculada com a satisfação de suas necessidades. Segundo Löbach (2001), a materialização de ideias para a satisfação das múltiplas necessidades do homem conduz à produção de diversos objetos, que podem se classificar em quatro categorias: objetos naturais, natureza modificada como objeto, objetos artísticos e objetos de uso. Esta última categoria de objetos passou por profundas mudanças no seu processo de produção ao longo da história conforme o homem foi aprimorando as técnicas de produção. 

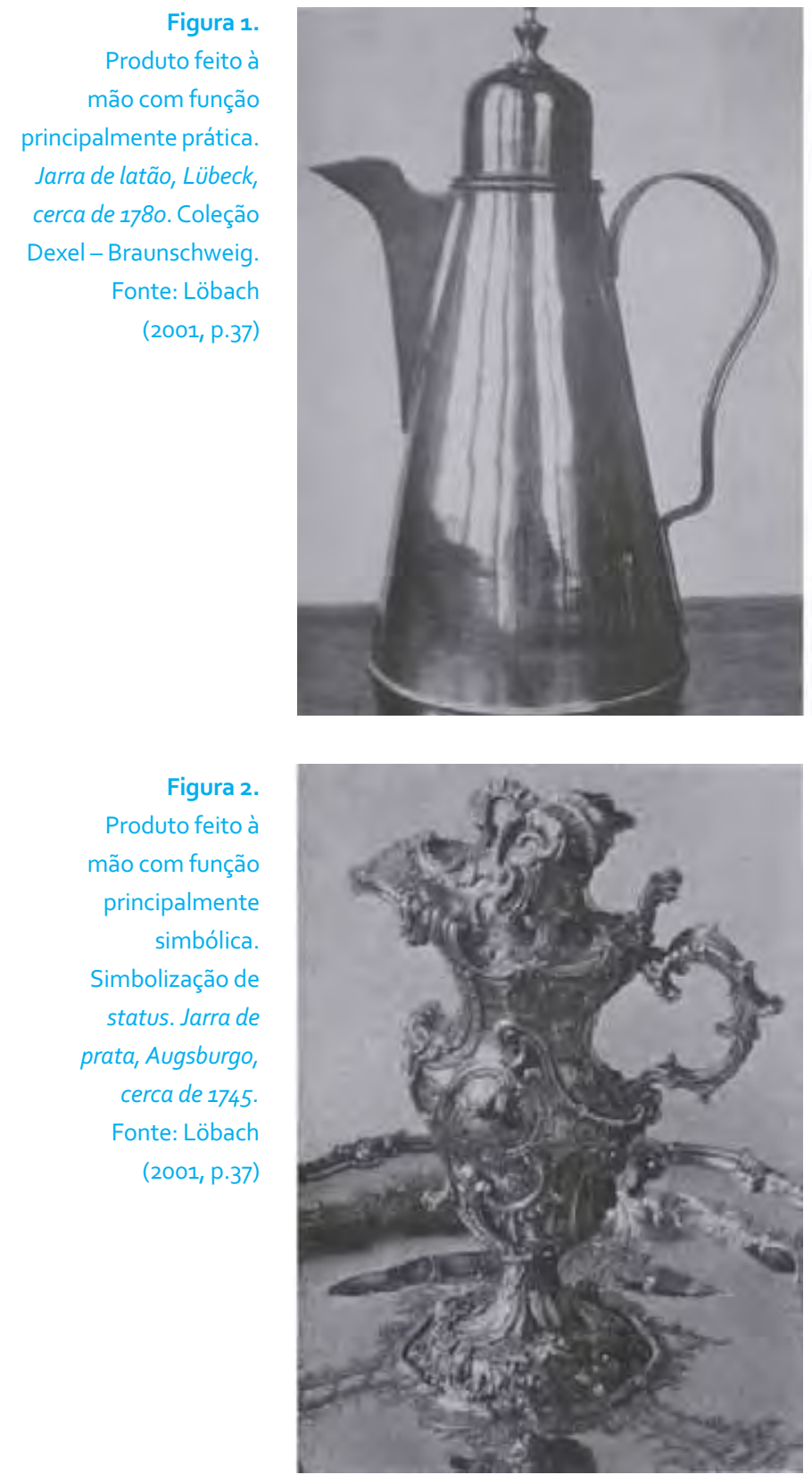

Uma das primeiras técnicas de produção de objetos de uso, bastante expressiva e que sobrevive até hoje, foi o artesanato, realizado através de manufaturas. Era preciso conhecimento técnico e de materiais, habilidade manual e das ferramentas disponíveis e criatividade para desenvolver novos produtos e novas técnicas de artesanato. Esses objetos eram desenvolvidos por completo pelo artesão, que possuía o domínio da técnica e tinha o controle de todo o processo. No caso do desenvolvimento de novos produtos o artesão também tinha que conhecer as necessidades a serem resolvidas e deveria se valer de um mínimo de planejamento, mesmo que inconsciente, para colocar em prática as suas ideias.

Conforme foi conhecendo e dominando os materiais de que dispunha, o homem desenvolveu e aprimorou as técnicas de produção artesanal e assim, os próprios produtos. À medida em que percebeu que os objetos satisfaziam suas necessidades, passou também a reproduzi-los, atendendo a um número maior de pessoas. De acordo com Löbach (2001), até a metade do século XIX os objetos artesanais se dividiam em duas classes segundo sua função: prática ou simbólica [Figuras 1 e 2]. 
Com o desenvolvimento das tecnologias o homem alterou em muito o processo de produção de seus objetos. Uma das maiores transformações neste aspecto, que se tornou referência na história da humanidade, foi a Revolução Industrial, no final do séc. XVIII, dando origem ao processo de produção industrial dos objetos. Além da mudança nos meios de produção, houve também grandes alterações e mudanças no modo de vida da população. De Masi (2000) cita as leis de racionalização impostas pela indústria: sincronização, estandardização, maximização, especialização, centralização e concentração [Figura 3]. Todas essas imposições geraram uma série de questionamentos por parte da população, de valores éticos, morais e culturais.

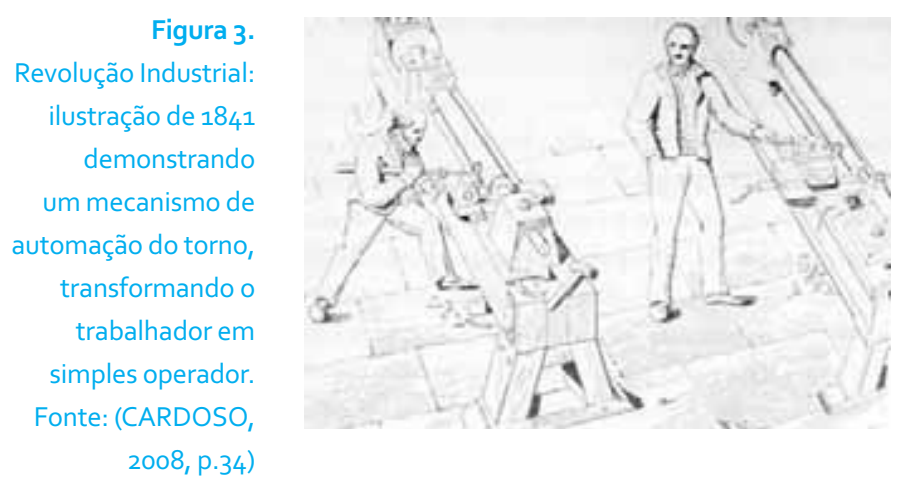

O artesanato, por sua vez, passa por uma fase de incertezas ao ser comparado com o produto industrial, que, além de ser mais acessível era muito mais rápido de ser produzido. Alguns movimentos de vanguarda européia tentaram valorizar o trabalho do artesão, em oposição à massificação da produção industrial. $\mathrm{O}$ movimento Arts and Crafts [Figuras 4 e 5] foi um dos mais influentes. Teve início na Inglaterra na segunda metade do século XIX, através de William Morris, inspirado nos ideais de John Ruskin, com o intuito de reavivar e restaurar a dignidade do artesanato tradicional e fazer uma arte que estivesse ao alcance de todos os bolsos (DEMPSEY, 2003). Entre outras coisas, Morris acreditava que a indústria sacrificava a qualidade em favor da quantidade. Porém, o objeto artesanal era caro e não tinha condições de competir com o objeto produzido industrialmente.

Em 1919, surge a escola Bauhaus, em Weimar, Alemanha, sob direção do arquiteto Walter Gropius, com o intuito de capacitar os alunos (artistas e artesãos) na teoria e na prática das artes, dando-lhes condições de criar produtos que fossem ao mesmo tempo artísticos e comerciais (DEMPSEY, 2003). Este novo profissional que surgiu na Bauhaus, o designer, começa a trabalhar junto à indústria, desenvolvendo os projetos dos objetos fabricados industrialmente - os produtos industriais. Assim nasce o design, de uma necessidade que a sociedade industrial sentiu, mais precisamente na Europa, em meados do século XIX, de criar mecanismos que pudessem dar nexo ao novo modo de produção de objetos e informações, ocasião em que surge o projeto industrial (ESCOREL, 2000). 
O design é uma atividade que envolve a criação, no sentido de projetar, ou "estabelecer qualidades" multi-facetadas de objetos, processos, serviços e seus sistemas em todos os ciclos de vida (ICSID, s.d). Portanto o design é, na sua essência, uma atividade de projeto. A grande mudança no processo, além da inserção da máquina, passa a ser a utilização de um projeto, desenvolvido pelo profissional designer, pois mesmo no processo industrial, o projetista continua se valendo dos mesmos aspectos da produção artesanal: conhecimentos, habilidades e criatividade para desenvolver novos produtos, além de conhecer as necessidades a serem resolvidas. Como a grande diferença situa-se no âmbito do projeto, a necessidade de planejamento se torna ainda maior, já que o designer não tem mais o controle total de todo o processo.

Isso fica ainda mais claro ao analisar a história do design gráfico, que tem suas origens na tipografia, fase muito anterior à Bauhaus, evidenciando a utilização de planejamentos anteriores à execução da obra. A Revolução Industrial só tornou mais forte a necessidade de planejamento dando origem ao projeto como forma, entre outras coisas, de otimizar a produção, diminuindo os prejuízos.

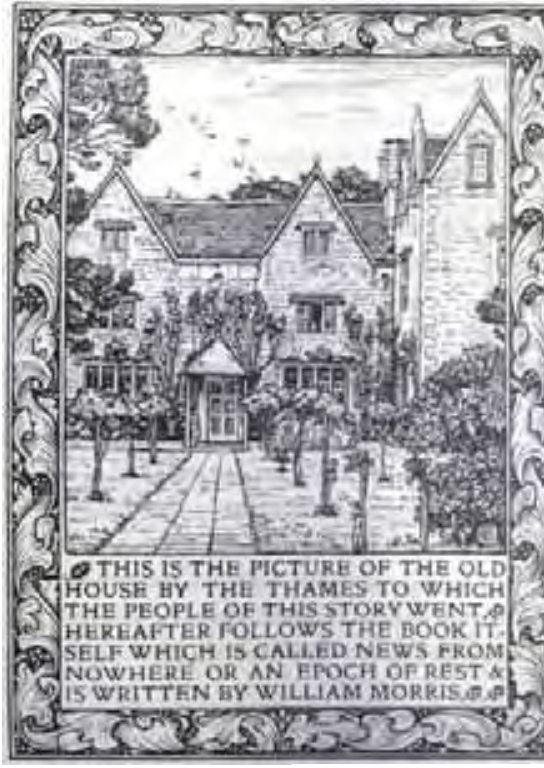

Figura 4.

Frontispício da

edição de News From

Nowhere: exemplo

raro da atuação de

Morris como autor

designer e editor de

uma só vez. Fonte:

Cardoso (2008, p.83)

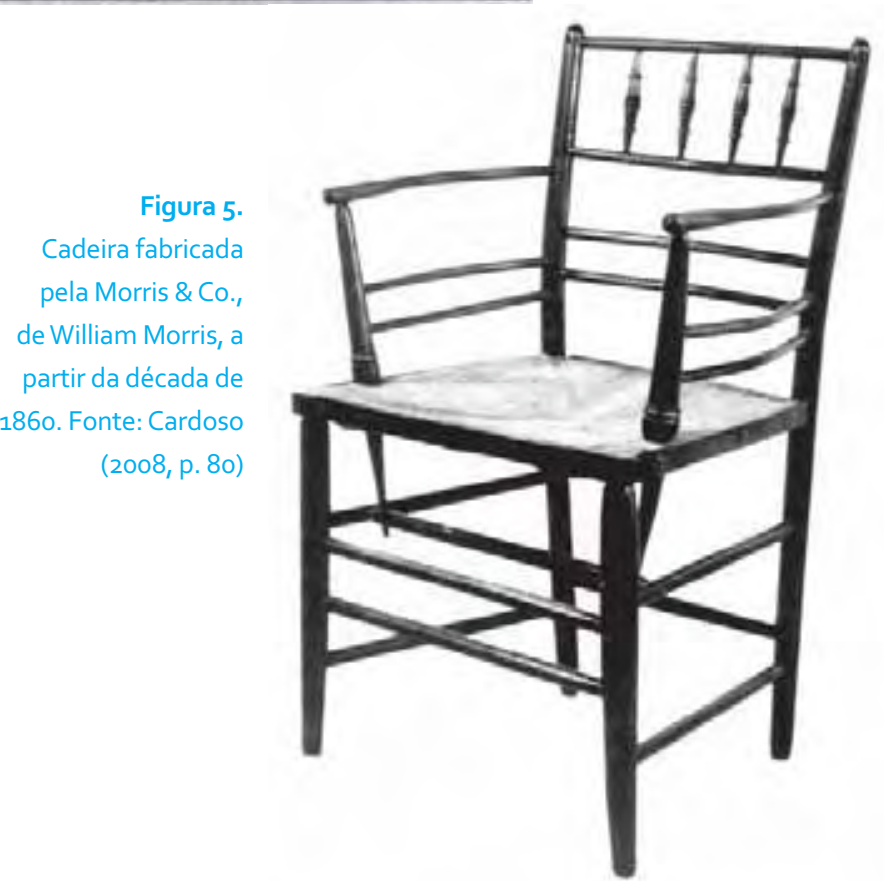




\section{Metodologia e \\ criatividade no processo}

Todo projeto depende de um processo. Do começo ao fim há um conjunto de fatores e ações dentro do projeto que permitem que uma ideia se transforme em um produto. Esse processo de desenvolver projetos em design é conhecido como Metodologia do Projeto. É um conjunto de orientações que visam facilitar a criação de modo a se chegar ao melhor resultado com o menor esforço possível (MUNARI, 1981), é a estruturação e organização do processo, necessidade básica da ação artística criadora: "essencialmente, o ato criador, [...] estrutura e organiza o mundo, respondendo aos desafios que dele emanam, num constante processo de transformação do homem e da realidade circundante" (BRASIL, 1997, p 26).

Desde o surgimento do design, vários professores e pensadores se puseram a refletir sobre a melhoria da Metodologia de Projeto. Na Bauhaus, o professor Johannes Itten foi o responsável por desenvolver o Workurs, ou Curso Preliminar, curso que tinha como principal objetivo ensinar aos alunos meios e formas de se conceber ideias para novos projetos. Através das mudanças de direção que a Bauhaus passou e com a aproximação da escola com a indústria, o processo de projeto passou a adquirir um carater mais científico 
Posteriormente na escola HfG (Hochschule für Gestaltung), em Ulm, os conceitos quantitativos adquiriram tanta importância que os problemas metodológicos passaram a ser considerados de primeiro plano, chegando a um estágio onde as etapas tornaram-se mais importantes que o próprio projeto (SOUZA apud PANIZZA, 2004). Nesse momento a metodologia de solucionar problemas no campo do design apoiava-se no método científico, e consequentemente, cartesiano de resolver ou entender os problemas, dividindo-o em partes, reflexo do momento histórico pelo qual a humanidade atravessava. Esse modelo de metodologia passou por alterações, mas se tornou base para muitas das escolas de design que se disseminaram pelo mundo, inclusive no Brasil.

Panizza (2004) apresenta uma análise das metodologias propostas por Bauhaus, HfG, Bruno Munari, Verônica Napoles, Don Koberg e Jim Bagnall, Norberto Chaves, Bernard Löbach, Maria Luísa Peón, Fábio Mestriner, Guto Lins e Francisco Homem de Melo. Apesar de várias diferenças nos modelos de metodologias apresentados pela autora, a razão, baseada no método cartesiano, de René Descartes, sempre foi uma constante na concepção dos projetos. Com exceção do modelo adotado pela ADG - Associação dos Designers Gráficos, de Francisco Homem de Melo, onde a questão da criatividade tem a mesma importância que os dados objetivos, a autora afirma que “o método é válido e precioso. É através dele que se obtém maior clareza do problema a ser resolvido, se organiza o processo de projetação e se assegura uma menor possibilidade de erro, mas o método não basta por si só; o se humano é extremamente complexo e sua interpretação e a do mundo em que vive depende de algo mais que a razão: é preciso também sensibilidade" (PANIZZA, 2004, p.158).

A partir da análise apresentada por Panizza (2004) fica claro que a questão das metodologias ainda não está resolvida e tem espaço para melhorias em vários aspectos. Medeiros (2004) lembra que a maioria das metodologias projetuais foram concebidas nas décadas de sessenta e setenta, para uma situação mundial diferente da que vivemos hoje, onde era necessário difundirem-se procedimentos gerais, padronizáveis, sistemáticos, lógicos e racionais em substituição a procedimentos intuitivos, tácitos e subjetivos. A mesma autora lembra dos mapas mentais do matemático canadense Tony Buzan, "método que consiste em escrever cinco ou dez palavras a partir de uma palavra central, onde cada palavra gerada poderá dar origem a outras tantas e, assim, uma abrangente visão dos conceitos é 'mapeada'" (MEDEIROS, 2004, p.53). 
Segundo Wollner (2003, p.19) “a exigência de um tempo de processamento inconsciente das possibilidades do problema para que se dê a eclosão do criativo hoje é explicada na hipótese do comportamento quântico da mente". Modelo recente de criatividade, baseado na física quântica, apresentado pelo físico Amit Goswami, professor da Universidade de Oregon, que consiste em 4 estágios não lineares: preparação, incubação, revelação e manifestação. Uma grande diferença em relação às metodologias convencionais consiste exatamente em respeitar o tempo de processamento inconsciente, evitando um colapso nos pensamentos.
Um dos trabalhos mais recentes na busca pelo gerenciamento do processo criativo no Brasil é apresentado por Gomes et. al. (2009), classificando-o de acordo com as operações mentais, conteúdos dos registros gráficos e tipos de composição do produto gráfico [Figura 6]. Através dessa classificação o processo criativo fica mais fácil de ser entendido, e portanto, mensurado e avaliado.

\begin{tabular}{|c|c|}
\hline Cogniça & visial \\
\hline & auditiva \\
\hline & tati \\
\hline & olfativa \\
\hline & gustativa \\
\hline \multirow[t]{3}{*}{ Rotanghan } & sensitiva \\
\hline & fisica \\
\hline & declarativa \\
\hline \multirow[t]{3}{*}{ Avallactiog } & técricu-funcional \\
\hline & estético-formal \\
\hline & |ógico-informacional \\
\hline Drodichlito & onvergente (iso/homeomerico) \\
\hline & rgente (singeno/catatemetrico) \\
\hline
\end{tabular}

\begin{tabular}{|c|c|}
\hline Unidades (linhas) & constelaçāo / delineaçăo \\
\hline Canses & configuraçă \\
\hline \multirow[t]{2}{*}{ Relasbles } & formação \\
\hline & coloraç,̄o \\
\hline \multirow[t]{3}{*}{ Sistemas } & diagramas \\
\hline & esquemas \\
\hline & leiautes \\
\hline \multirow[t]{3}{*}{ Thanstormincses } & bosquejos \\
\hline & esboços \\
\hline & ilustraçöes \\
\hline \multirow[t]{3}{*}{ rimplicacioses } & desenho de comunicacăo \\
\hline & desenho de ambiente \\
\hline & desenho de artefato \\
\hline
\end{tabular}

\begin{tabular}{|c|c|c|}
\hline Sigrificacional & sinal & Figura 6. \\
\hline & signo & Integração de modelos \\
\hline & simbolo & das habilidades \\
\hline \multirow[t]{3}{*}{ cuitural } & ideaçional & mentais manuaise \\
\hline & comportamental & expressionais aráficas \\
\hline & material & oressionals grancas. \\
\hline \multirow[t]{7}{*}{ Ideopiraficacional } & abongenográfico & Fonte: Gomes et. \\
\hline & pictográfico & al. (2009, p.371) \\
\hline & numerográfico & \\
\hline & moifegráfico & \\
\hline & logográfico & \\
\hline & silabigráfico & \\
\hline & alfabetigrä́fico & \\
\hline
\end{tabular}


De um modo geral fica claro como há avanços significativos das metodologias projetuais. O tempo de processamento citado por Wollner (2003) pode ser um grande avanço no desenvolvimento das metodologias projetuais em se tratando das questões de sensibilidade e respeito do indivíduo criador, inclusive no aspecto emocional, levantado por Panizza (2004). Já a classificação de Gomes et. al. pode contribuir significativamente para o ensino e consequente prática do processo e, por que não, para questões de credibilidade e regulamentação nas profissões que lidam com a atividade de projetação, já que a sociedade atual ainda valoriza muito só aquilo que pode ser calculado. 


\section{Tempo do processo}

Independente da metodologia adotada na concepção dos produtos, os processos podem demorar mais ou menos tempo em função de vários fatores mas, em especial, da complexidade do projeto.

Semelhante ao que aconteceu na Revolução Industrial, no séc. XVIII, onde a evolução tecnológica levou a uma aceleração do processo de produção [Figura 7], houve também uma grande mudança, no final do séc. XX, com a inserção da informática nesse processo. O tempo de desenvolvimento dos projetos em design diminuiu consideravelmente, porém isso não quer dizer que a qualidade dos projetos e dos produtos tenha aumentado. Essa ânsia em diminuir o tempo, de sempre fazer mais no menor tempo possível parece perseguir e impulsionar a humanidade, na sua evolução tecnológica.

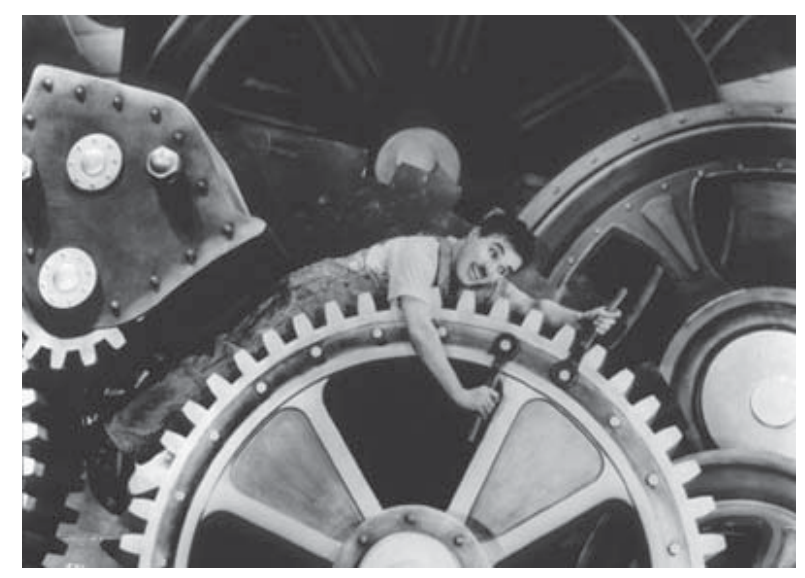


Um aspecto negativo nessa tendência por diminuir o tempo parece envolver uma busca em diminuir o processo, automatizá-lo, ou informatizá-lo. Diminuir o processo também ilustra alguns dos valores que vêm dominando a nossa sociedade, como o lucro fácil, o sucesso rápido, enfim, resultados imediatos. Valores ou vantagens que podem ocultar ou menosprezar o real valor do trabalho e do processo, entendidos aqui como o tempo para "digerir" uma informação.

Com os processos cada vez mais informatizados, gera-se ansiedade na busca de resultados e, com isso, parece haver uma tendência ao comodismo e à ilusão ou desejo do homem, de que o trabalho é coisa das máquinas e cabe ao ser humano somente usufruir dos resultados obtidos através delas. Porém, resultados dependem de processos, automatizados ou não, e que têm papel fundamental no desenvolvimento de todo produto. Tanto que, desde o surgimento do design, as metodologias e processos criativos vêm sendo estudadas e aprimoradas.
Não se pode esquecer que o processo é a essência. Talvez seja até um problema cultural essa valorização excessiva por resultados. Os processos é que devem ser valorizados pois os resultados são apenas conseqüência dos processos. Não se defende aqui um tipo de processo específico, um método ou receita eficaz de resolver problemas. Entretanto, acredita-se que os processos utilizados até agora, ainda não são suficientes para resolver problemas como um todo. Panizza (2004) coloca que a receita [no caso da metodologia de Mestriner, entendidos aqui como receitas de forma geral] não prevê a interferência do designer gráfico como indivíduo, é a aplicação pura de um método racional e analítico, resultado, talvez, de uma sociedade apaixonada pela razão, baseada no pensamento cartesiano que separa a mente do corpo e a razão das emoções.

Nakata (2003) afirma que o processo lento, de erros e acertos na construção de uma circunferência feita à mão livre aprimora a sensibilidade para a percepção visual, enquanto que, no meio digital, o processo é imediato, anulando a possibilidade de desenvolver essa mesma percepção. Portanto quando se trata de ensinar, ou de aprimorar conceitos, os processos exercem uma influência ainda maior. Assim, entende-se que o cultivo do 'resultado imediato' e das 'facilidades do processo informatizado' podem contribuir para menosprezar o valor e o trabalho do processo criativo, prejudicando o aprendizado. 
Radfahrer (s.d) faz uma analogia semelhante, entre talento e preguiça, para mostrar que o talento está muito mais associado ao trabalho (e neste caso, da valorização do processo) do que a um dom divino.

"O trabalho em criação é uma habilidade como outra qualquer. Para se arriscar a viver dele é necessário algum talento inicial, mas isso não é o suficiente. A prática deve ser desenvolvida com muitos exercícios e trabalho duro, até que o processo seja natural. [...] Não adianta ler um montão de livros de design de uma vez, como não adianta fazer 1.400 abdominais se você é sedentário. O que vale é mudar de postura, fazer o cérebro se mexer, alimentá-lo com ideias doidas, coletar referências de todos os lados e, acima de tudo, não esperar resultados rápidos. A cultura, como a fisicultura, demanda tempo.[...] Infelizmente, a maioria das pessoas não começa pelas partes, mas pelo todo e o quer pronto sem disposição ou esforço. Essa cultura fast-food é fácil de se identificar: está em gente que larga academias ou cursos de instrumentos musicais, desiste de escolas de línguas e acredita em emagrecimento milagroso. Impressionáveis, não percebem que a busca por um resultado sem atenção na dedicação e detalhe só gera frustração e angústia. Pra piorar, a tal 'sorte de principiante' só atrapalha, pois falta aos espertinhos, que acertam no primeiro lance e se julgam geniais, a dedicação, o que gera ainda mais insatisfação a médio prazo. [...] ... como diria o filósofo Nietzsche: 'acreditar que um artista seja genial e não dar valor a um professor ou engenheiro não passa de uma infantilidade da razão'." (RADFAHRER, s.d., p.181,183 e 21)
Wheeler (2008) faz uma comentário sobre a importância do processo para realização de identidade de marca, que pode servir também como referência para todos os processos de criação:

"O processo de identidade de marca é um método provado e disciplinado para criar e implementar uma identidade. É um processo rigoroso que demanda uma combinação de investigação, pensamento estratégico, excelência em design e habilidade no gerenciamento de projetos. Ele requer extraordinária quantidade de paciência, obsessão de fazer as coisas corretamente e capacidade de sintetizar grandes quantidades de informação. [...]Independente da natureza do cliente e da complexidade do compromisso, o processo é sempre o mesmo. O que muda é a profundidade em que cada fase é conduzida, a extensão do tempo, os recursos que são atribuídos e o tamanho da equipe em ambos os lados, a empresa especializada em identidade e o cliente. [...] O processo é definido por fases distintas com pontos lógicos de início e finalização, o que facilita as tomadas de decisão nos intervalos apropriados. A eliminação de etapas ou reorganização do projeto pode apresentar uma atraente forma de cortar custos e tempo, porém, isso pode acarretar riscos substanciais e impedir benefícios a longo prazo. processo, quando feito corretamente, pode produzir resultados extraordinários" (WHEELER, 2008, p.80). 
Todos esses levantamentos reforçam a importância do respeito e valorização do processo, mas como ensinar os alunos a desenvolverem projetos valorizando o processo? Florio (2008) afirma que a análise dos croquis em arquitetura permite destruir os mitos da genialidade, do dom inato e da criatividade sem esforço. Mitos que parecem refletir os valores do resultado imediato citados há pouco. Assim, entende-se que a análise e a própria prática dos desenhos de expressão utilizados em projetos de design valorizem o processo e o trabalho como um todo. O mesmo autor completa que a qualidade do projeto deriva da capacidade do profissional de realizar operações cognitivas que combinem conhecimentos, habilidades, sensibilidade, experiências e principalmente, no presente caso, muito trabalho, reforçando sua valorização e, assim, a valorização do próprio processo.

Diante de tais levantamentos, cabe lembrar que não há como negar os avanços que a tecnologia proporcionou para a humanidade, em várias áreas do conhecimento. Contudo, percebe-se que há outras questões que também têm suas importâncias e que foram encobertas ou até esquecidas em virtude da evolução tecnológica. Assim, a análise e o estudo dos meios tradicionais de projetação (lápis e papel), e sua comparação com os meios informatizados de projetação adquire maior importância para esta pesquisa. 


\section{Computador no processo}

A inserção dos computadores no processo de projeto alterou em muito as formas de se projetar. Modificou as possibilidades de manipulação do projeto e do processo criativo. Hoje é comum que cada designer trabalhe à frente do seu computador, do começo ao fim do projeto. Porém, vários estudos e pesquisas que confrontam os meios tradicionais (lápis e papel) com os meios informatizados no processo criativo, apontam que o meio tradicional ainda leva vantagem em relação ao meio informatizado. Medeiros (2004) coloca que

\footnotetext{
"A observação e a revisão de literatura demonstram que, apesar dos muitos programas CAD disponíveis, ainda é dominante a prática de iniciarmos o estudo visual com rascunhos das primeiras ideias no papel, à lápis. Quando boa parte das decisões conceituais já foi tomada, e iniciam-se as etapas de pré-produção e de produção industrial, sistemas de comunicação gráfica mais precisos e formalizados tornam-se necessários. Nas etapas preliminares, entretanto, 'os rascunhos são econômicos e podem ser transportados rapidamente, e transformações são fáceis de realizar'[...]. Esta preferência pode decorrer do desconhecimento de como aproveitar plenamente os recursos informatizados, mas pode, também, ser conseqüência da forte sintonia cognitiva existente entre as atividades típicas de início do projeto e os meios informais de representação." (MEDEIROS, 2004, p. 45)
} 
Carvalho et. al. (2005) apresentam alguns estudos de comparações entre os meios tradicionais (lápis e papel) com os meios digitais (computador) na concepção de projetos arquitetônicos. Os indivíduos que utilizaram a mídia a lápis obtiveram: menor tempo na execução dos projetos; maior freqüência de ações físicas, perceptivas, funcionais e conceituais; maior número ações cognitivas, maior número de variações de uma idéia. O menor tempo na execução dos projetos mostra que o homem caminha em direção contraria à uma evolução no processo, utilizando o computador na criação como forma de diminuir o tempo de execução. Ou pelo menos mostra que não está evoluindo enquanto não tiver um domínio adequado sobre essa ferramenta. O mesmo autor cita alguns pontos importantes da pesquisa:

1 - A forma como a ferramenta computacional estruturase e constrói sua interface com o usuário, impõe níveis de precisão, rigidez e compromisso que pressionam o arquiteto a tomar decisões antes que este esteja preparado a fazê-las.

2 - A falta de compreensão e domínio da ferramenta computacional por parte do usuário limita a utilização da computação gráfica tornando-a mais uma ferramenta de representação do que de concepção.

3 - Existem diferenças significativas entre as ações cognitivas dos arquitetos, na fase de concepção do projeto, quando estes utilizam mídias distintas (lápis x CAD);

4 - O uso da mídia tradicional favorece uma melhor compreensão do problema projetual. (CARVALHO et. al., 2005, p.10).
Esta última afirmação reforça uma das hipóteses mais pertinentes da presente pesquisa: o uso do desenho de expressão como forma de visualizar ou compreender o problema em seus aspectos fundamentais, para só depois dar seguimento às fases posteriores de desenvolvimento do projeto.

Uma constatação bastante interessante que o mesmo autor levanta é o fato de que os projetistas passavam bastante tempo parados, refletindo diante da tela do computador, enquanto que na mídia tradicional estes encontravam-se sempre rabiscando. Este fato observado pelo autor mostra que o projetista não materializa aquilo que está pensando quando tenta criar diretamente no computador, ou seja, tenta resolver tudo através de reflexões intelectuais, ou pelo menos não materializa tanto quanto na mídia tradicional, limitando as possibilidades de solução de um problema.

O fato mencionado acima espelha aquilo que foi constatado e apresentado na introdução desta pesquisa, em que os estudantes de design ficavam 'divagando' na frente do computador sem saber direito o que fazer, ou como fazer, refletindo muito e exteriorizando pouco.

Há de se considerar que o computador é uma ferramenta nova e talvez o homem ainda não tenha aprendido a conciliar e usufruir de suas possibilidades. Isso porém não tira a responsabilidade de questionar as ferramentas computacionais, para que se faça um melhor uso delas, como afirma Martino (2007): 
"É necessário nos atentarmos como este novo universo (digital) que vem se implantando, realizando prognósticos e diagnósticos capazes de nos orientar da melhor maneira possível, contribuindo para a construção de uma era digital coerente com as suas possibilidades e potencialidades" (MARTINO, 2007, p. 76).

Cabe aqui também a afirmação de Castells apud Almeida (2007, p. 5): "As novas tecnologias da informação não são simplesmente ferramentas a serem aplicadas, mas processos a serem desenvolvidos."

Ainda assim parece limitante demais, ou pretensioso demais, acreditar que com o computador possa se resolver todas as questões pertinentes à criação de um projeto. Existem outras atividades como a pesquisa de campo e bibliográfica, a troca de informações entre outras pessoas, as discussões, e também as emoções, que incluem o indivíduo como um todo. Aspectos que transcendem o computador e que também podem contribuir para o desenvolvimento projetual.
Segundo Carvalho et. al. (2005) as mídias tradicionais, se comparadas às mídias digitais atualmente usadas, são mais fluidas e mais apropriadas para o desenvolvimento rápido e inicial das ideias, o estímulo à imaginação, à investigação livre, à referência cruzada intencional e randômica de fontes diversas, à manipulação e visualização de escala, à expressão de estados emocionais etc. As mídias digitais são bastante adequadas às fases de desenvolvimento do projeto, já que estas exigem níveis mais altos de definição geométrica e a elaboração e coordenação de complexidade e detalhes, permitindo a fácil articulação e a geração de múltiplos pontos de vista.

Além da inserção do computador no processo criativo, há a etapa de análise ou aprovação que também vem sendo incorporada pelo computador; porém Almeida (2007) afirma que é grande a discussão entre arquitetos dos riscos da análise apenas através de perspectivas ou modelagens virtuais e apregoam a necessidade da maquete tradicional, que é incapaz de enganar o cliente. De modo semelhante no design gráfico, as maquetes ou "bonecas ${ }^{1 "}$ nem sempre são utilizadas para aprovação de um projeto, sendo este avaliado somente pela representação digital na tela do computador. Mesmo no design, há o risco deste tipo de avaliação, desde o tipo de iluminação que a tela do computador proporciona causando variações na percepção de cores até percepções de manuseio, dobras, tato, sentimento, emoção etc. 
O computador, além de possibilitar inúmeras alternativas de manipulação das informações, trouxe também o problema da dispersão das informações, fazendo com que se perca o foco do problema, permitindo que o projetista que ainda não tem experiência, pule etapas. O computador possibilita uma não linearidade na manipulação das informações que, por um lado, pode ser produtiva ao permitir o acesso simultâneo de várias informações, mas, por outro lado, pode dispersar o criador, se este não tiver clara consciência do objetivo e foco do problema a ser resolvido.

No design gráfico, o fato de muitos produtos se caracterizarem por aspectos bidimensionais, assim como é a tela do computador, parece criar uma ilusão de que os projetos são mais fáceis de serem desenvolvidos, ignorando-se as fases tradicionais do lápis e papel. Talvez por isso exista uma insistência por parte dos novos profissionais no desenvolvimento de projetos gráficos sem o uso do desenho expressional, criando diretamente no computador. Nakata (2008) lembra que

"na banalização da imagem no meio da comunicação impressa com advento dos recursos tecnológicos, mais especificamente de computação gráfica, verificou-se um acentuado uso das imagens sem critério e qualidade na produção das peças gráficas. Por um lado, esses avanços tecnológicos proporcionaram para alguns ilustradores e designers a possibilidade de se aprimorarem nas técnicas e na elaboração de ilustração e design. Por outro, houve esse notório uso indiscriminado que levou a um panorama de imagens impressas sem controle de qualidade e conceito e, sobretudo, sem valores agregados às ideias estampadas nestas peças gráficas" (NAKATA, 2008, p.3935).
No Guia do Ilustrador, Antunes (s.d.) reforça essa ilusão que é criada pelo uso do computador e da importância do repertório para o profissional:

"ter toda uma formação cultural, intelectual e artística dará ao ilustrador a segurança de ser um bom profissional e a possibilidade de se destacar no mercado, visto que hoje em dia o computador tem nivelado por baixo o padrão de qualidade de muitos ilustradores iniciantes (e muitos que já estão no mercado). O computador é uma excelente ferramenta, mas não vai fazer tudo por você, não vai criar talento por você, e acima de tudo, não vai pensar por você. Infelizmente muitas vezes não é bem isso o que se vê por aí..." (ANTUNES, s.d., p.5).

Nos estúdios da Disney/Pixar, nos Estados Unidos, são desenvolvidas animações de altíssimo nível, com recursos computacionais de última geração. Curiosamente, o processo de criação valoriza extremamente o uso dos desenhos de expressão [Figura 8] como forma de reflexão e ajuste, organização, especulação para a obra para, somente depois, passar à construção e animação digital dos personagens, inclusão de trilha sonora e outros detalhamentos (Anexo F). Essas animações são muito complexas e por isso se justifica um grande planejamento antes da execução do trabalho. Além disso, envolve muitas pessoas e um retrabalho muito grande poderia acarretar muitos prejuízos. 


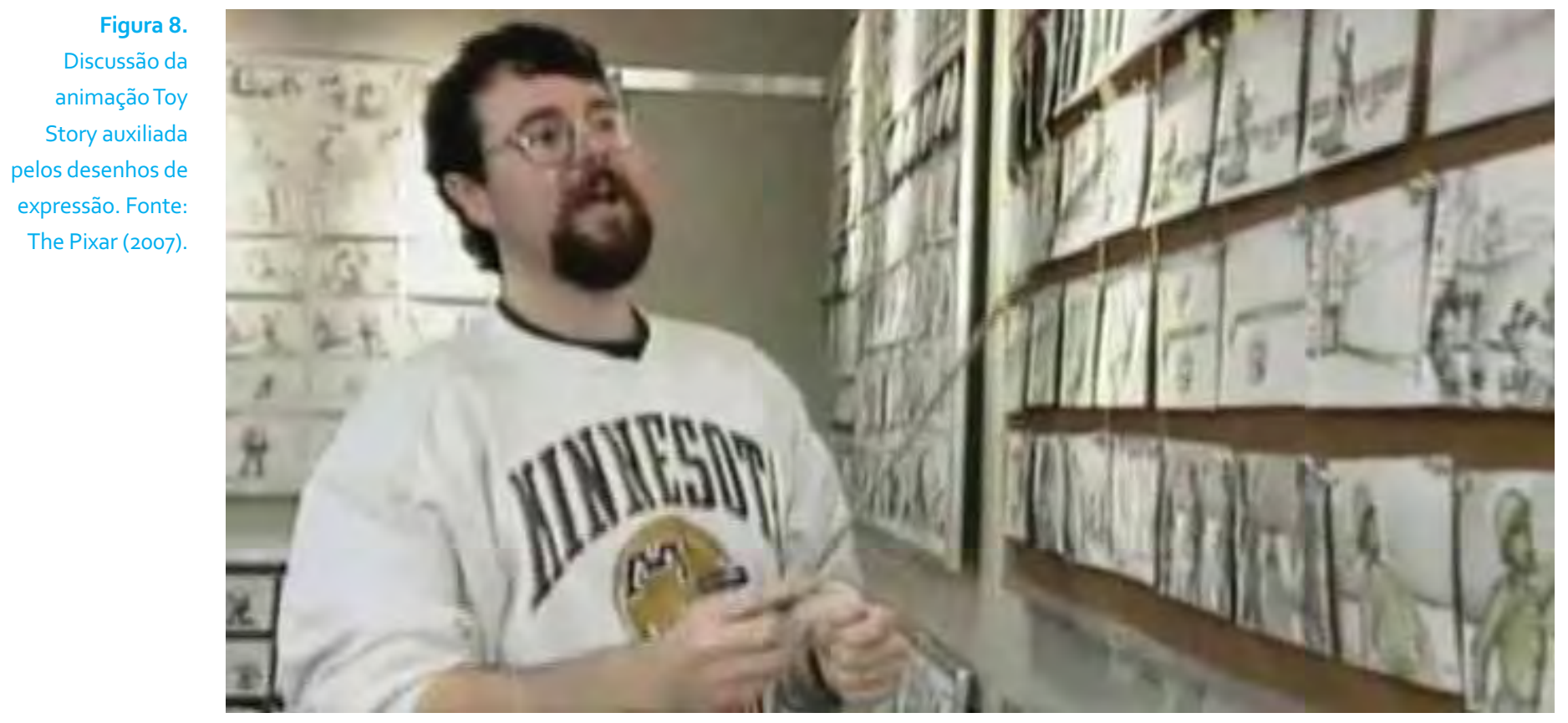

Mesmo com as evidências de vantagens do processo tradicional sobre o processo digital na concepção de projetos em comunicação visual, vale lembrar que as tecnologias estão em constante evolução, permitindo uma melhor integração do homem com a máquina. Exemplos disso são as mesas digitalizadoras, as telas sensíveis ao toque e os equipamentos que respondem a comandos de voz. Porém, cabe ao homem também aprender a lidar com essas ferramentas. O computador e seus periféricos são ferramentas novas que, ao ampliarem as possibilidades de manipulação de uma imagem, ampliam também a necessidade de conhecimento para se utilizar melhor essas possibilidades disponíveis, caso contrário a ferramenta torna-se um empecilho se não se sabe utilizá-la.
A partir desses levantamentos fica claro que a habilidade e domínio sobre a ferramenta é fator crucial para que ela contribua de forma efetiva à função pela qual foi atribuída e essa atribuição é definida pelo designer que, de acordo com seu projeto, seleciona quais instrumentos e recursos serão mais adequados ao desenvolvimento das tarefas e resolução dos problemas. 


\title{
Capítulo 2
}

\section{O desenho no processo de projeto}

\author{
Desenho no processo 25 \\ Desenhos de expressão 27 \\ Desenho expressional e suas transformações 32 \\ Cadernos de rascunhos 37 \\ Desenho expressional e organização de ideias 41 \\ Desenho expressional e projetos 46
}

"O desempenho no desenho-projetual é facilitado quando se conjugam os fatores fluência no desenho-expressional com o conhecimento sobre

como controlar os processos mentais. A fluência sozinha pode até atrapalhar, pois quem só ilustra, com ou sem auxilio do computador, acaba gerando imagens aparentemente completas, muito elaboradas e limpas já de início. Isso pode levar o desenhador a antecipar etapas e ir direto para o que parece ser o fim do trabalho, sem se dar a chance da experimentação antes de definir soluções. Já o conhecimento das operações cognitivas sem alguma fluência gráfica pode conduzir a formulação de projetos exclusivamente mentais, caracterizados pelo uso da modelagem cognitiva, sem apoio na modelagem produtiva" (MEDEIROS, 2004, p. 112-113). 


\section{Desenho no processo}

"Desenhar é preciso"

(NIEMEYER apud

MELO, 2000)

A forma de projetar é uma prática tradicional e artesanal, baseada em desenhos (PERRONE et. al., s.d.). O desenho é a base de qualquer trabalho visual, bi ou tridimensional (JUNIOR E RÊGO, 2005), é o processo ou técnica de representação (gráfica) de alguma coisa - um objeto, uma cena ou uma ideia por meio de linhas, em uma superfície. Como se apresenta, geralmente, através de uma natureza linear, pode incluir outros elementos pictóricos, como pontos e pinceladas, que também podem ser interpretados como linhas. Qualquer que seja a forma do desenho, ele representa o princípio com base no qual organizamos e expressamos pensamentos e percepções visuais. Portanto, devemos olhar o desenho não só como expressão artística, mas também como ferramenta prática para formular e trabalhar em questões de representação gráfica (PEREIRA et.al., 2005)

No processo de elaboração de projeto, a função do desenho expande-se para registrar o que existe; as ideias que surgiram, as especulações e os planos a serem resgatados no futuro. Durante o processo de projetar, o desenho é utilizado para guiar o desenvolvimento de uma idéia, desde o conceito até a proposta concreta (PEREIRA et. al., 2005). 
Os designers se utilizam de vários tipos de desenhos ao longo do processo projetual. Existem aqueles desenhos mais precisos, detalhados, realizados com auxílio de ferramental a fim de indicar instruções gráficas que serão interpretadas por outras pessoas ou máquinas. Existem também aqueles desenhos mais expressivos, executados normalmente à mão livre, com lápis sobre papel na fase de concepção, que são foco desta pesquisa:

"O desenho expressional nomeia o universo de meios gráficos [...] utilizados para representação de ideias até a etapa de Iluminação, pois, a partir daí, o processo criativo exige esforço intensivo de detalhamento e redução de incertezas" (MEDEIROS, 2004, p.42).

Este tipo de desenho vem sofrendo uma crise desde a inserção da informática no processo de projeto, que, por fazer parte do desenho-projetual, também sofre conseqüências do descaso no ensino brasileiro:
“Infelizmente, as disciplinas ligadas ao desenho-projetual têm sido negligenciadas no ensino fundamental e médio no Brasil. Está sendo perdido o potencial de estudo e experimentação peculiar a essas disciplinas, que permitem o desenvolvimento do pensamento produtivo, além da descoberta de vocações e talentos para o trabalho individual e cooperativo de projeto. A lacuna deixada pela ausência de suporte instrucional para desenho-projetual nos ciclos iniciais da escolarização é acentuada, posteriormente, pela estrutura fragmentada dos cursos superiores, o que, muitas vezes, impede professores e estudantes de terem uma visão em perspectiva de seus objetivos e de seu papel na sociedade" (MEDEIROS, 2004, p. 1-2).

Portanto, o ensino do desenho expressional necessita de atenção, já que faz parte do desenho-projetual (que é insatisfatório no Brasil) e é reconhecido como via de acesso relevante à atividade mental no momento em que conhecimentos são empregados, para enriquecimento conceitual do projeto (MEDEIROS 2004, p. 42). 


\section{Desenhos de expressão}

Entre os desenhos de expressão utilizados na concepção de projetos industriais, ainda não há um consenso sobre o uso dos termos, gerando dúvidas e confusões. Essa confusão existe tanto devido à origem cultural diferente de cada termo, quanto da área onde é empregado, que também deriva de aspectos culturais. Os termos com origens diferentes nem sempre são equivalentes em seus significados. No Brasil, devido à origem cultural bastante diversificada, muitos dos termos em língua portuguesa foram esquecidos ou até substituídos por influências de origem estrangeira. Medeiros e Gomes (2005) salientam que

“os grandes campos do desenho projetual no Brasil carecem de definição taxonômica e terminological, essencia para a efetividade na comunicação entre professores, estudantes, pesquisadores e profissionais de desenho projetual. Uma linguagem verbal sistematizada é condição necessária para o crescimento e consolidação de qualquer área de investigação" (MEDEIROS E GOMES, 2005, p.7). 
Entre os termos utilizados para designar o desenho-expressional no Brasil, nos vários tipos de projetos industriais, encontramse: rascunho, esboço, croqui, rafe, rough, sketch, esquete. Termos que variam conforme a área de utilização, seja na arquitetura, na engenharia ou entre as diversas vertentes do design. Porém, mesmo nos principais dicionários da área, alguns termos não são contemplados. Esses desenhos também possuem diferenças significativas de acordo com o grau de transformações que apresentam. Portanto, já que todos eles representam "intenções de projeto", o termo "desenho de expressão" ou "desenho expressional" é adotado nesta pesquisa como forma de integrar todas as peculiaridades que este tipo de desenho tem.

Através do desenho expressional, o projetista vai fazendo correções e alterações, melhorando o desenho e tornando-o o mais próximo de suas intenções. E à medida que ele faz essas alterações, o desenho torna-se mais preciso ou detalhado, deixando de caracterizar-se como desenho-expressional.
O desenho expressional é um tipo de desenho fundamental, comunicação de ideias em fase embrionária, um estimulante criativo que abre caminhos para descobertas, e que aos poucos vai ganhando força no processo criativo até sua finalização projeto (PEREIRA et. al., 2005). Tem a função de exprimir aquilo que o projetista tem em mente, se constrói a partir de imagens mentais, que nem sempre são muito claras e são registradas em forma de linhas, traços ou manchas, normalmente através de lápis sobre papel, gerando interpretações pelo próprio criador a partir de sua relação cognitiva com o desenho, estimulando novas ideias. É um recurso de apoio à visualização, construção e interação com a idéia.

Segundo Montenegro (2007), projeto é uma idéia, resultado da imaginação criadora, escolhendo entre centenas de fatores aqueles que devem prevalecer. A habilidade e o conhecimento serão as bases para equilibrar a arte e as ciências técnicas do projeto. Portanto, fazer uma planta está ao alcance de qualquer pessoa, de qualquer profissão. Elaborar um projeto é alguma coisa mais séria e o arquiteto ainda que tenha muita experiência e capacidade precisa parar, pesquisar, pensar, riscar, discutir e tornar a riscar. Duas, três, dez, vinte vezes [...]. Pouco a pouco o projeto vai tomando a forma em esboços, discussões e novos esboços. Essa atitude que o autor coloca, de "tentar várias vezes" através do desenho expressional ilustra a importância que esse recurso exerce mesmo para os profissionais experientes, e, no caso daqueles que ainda não têm experiência esse recurso se torna mais importante ainda. 
As ideias e projetos mais complexos tendem a ser mais difíceis de serem visualizados somente através do pensamento, exigindo mais recursos, como o desenho expressional, para a sua visualização. Funciona com um diálogo entre o criador e sua idéia, permitindo novas interpretações e relações que talvez não fossem possíveis só na mente.

"O desempenho no desenho-projetual é facilitado quando se conjugam os fatores fluência no desenho-expressional com o conhecimento sobre como controlar os processos mentais. A fluência sozinha pode até atrapalhar, pois quem só ilustra, com ou sem auxílio do computador, acaba gerando imagens aparentemente completas, muito elaboradas e limpas já de início. Isso pode levar o desenhador a antecipar etapas e ir direto para o que parece ser o fim do trabalho, sem se dar a chance da experimentação antes de definir soluções. Já o conhecimento das operações cognitivas sem alguma fluência gráfica pode conduzir a formulação de projetos exclusivamente mentais, caracterizados pelo uso da modelagem cognitiva, sem apoio na modelagem produtiva" (MEDEIROS, 2004, p. 112-113).

O desenho-expressional também necessita de fluência e conhecimento. Este último pode ser baseado no repertório individual para ser executado. Porém o repertório pode ser fruto de estereótipos. Para que o desenho-expressional não expresse somente o repertório e as ideias "prontas" ou estereotipadas do projetista, é necessário o enriquecimento desse repertório, que pode ser feito de várias maneiras: através de pesquisas de similares ou de campo, ou levantamento de dados, conversas, bate-papos, enfim, informações que complementam e fomentam outras ideias.
Para a criação da obra "A Adoração dos Magos" [Figura 9], Leonardo da Vinci, provavelmente, utilizou obras que serviram como referência ou mesmo inspiração [Figura 10] (ZÖLLNER, 2006).

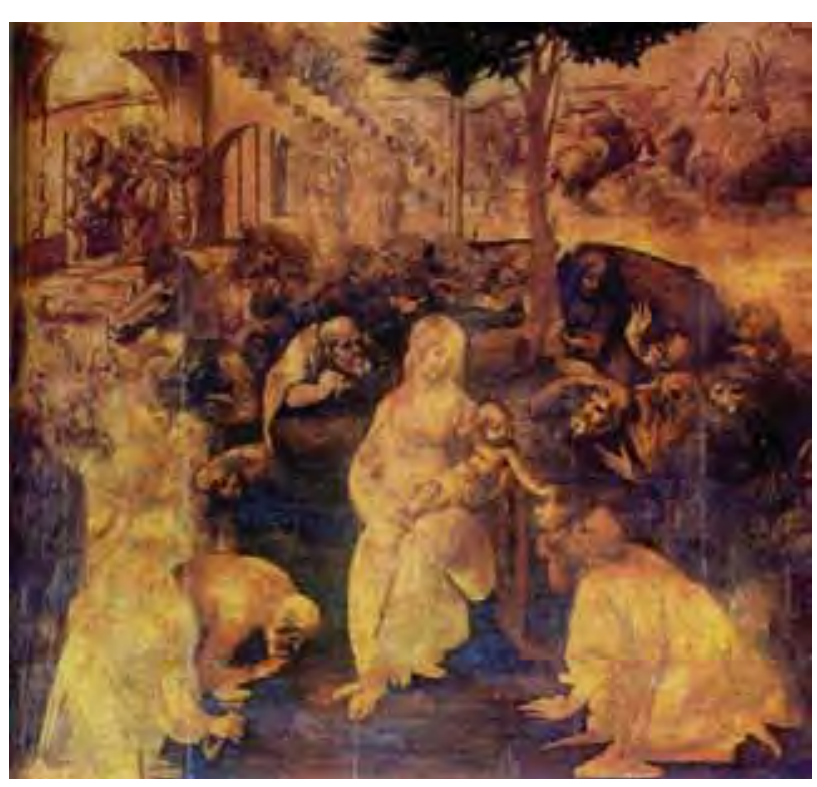

Figura 9.

"A Adoração dos Magos": obra

incompleta, à óleo sobre madeira, de Leonardo da Vinci, 1481. Fonte: Zöllner (2006, p.25).

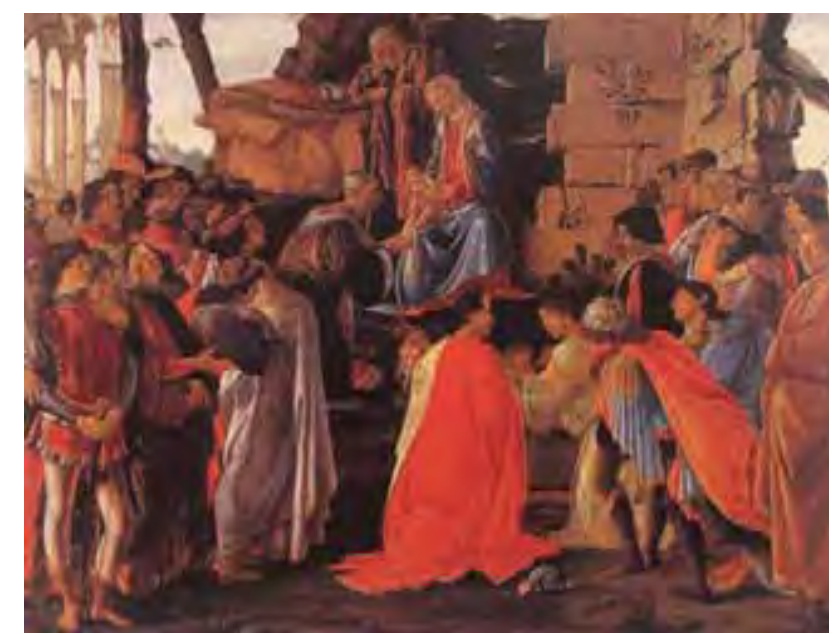

Figura 10.

"A Adoração dos Magos" para Gaspare Del Lama (cerca de 1472-1475), de Sandro Botticelli: obra que pode ter inspirado Leonardo da Vinci em sua "A Adoração dos Magos", de 1481. Fonte:

Zöllner (2006, p.24) 
Leonardo ainda fez vários estudos [Figuras 11 e 12] antes de definir a composição final para sua obra.

A fluência exige habilidade nos recursos que serão utilizados para sua execução. No caso de desenho expressional, existe a necessidade de habilidade no desenho à mão livre, no manuseio do lápis, para que coloque o traçado no lugar desejado. Saber desenhar requer o desenvolvimento de habilidades de percepção, de memória, diálogo e imaginação (EDWARDS, 1984). No desenho-expressional, o designer vale-se também de conhecimentos básicos de Geometria Descritiva, Desenho Técnico, projeções ortogonais (rebatimento do objeto no espaço), cortes e perspectivas (JUNIOR E RÊGO, 2005).

Assim como desenvolver a habilidade para tocar um instrumento musical, a habilidade para executar desenhos de expressão exigirá prática constante, principalmente para aquelas pessoas que não tem o hábito do desenho (JUNIOR E REGO, 2005). A prática constante permite que a pessoa adquira fluidez e desenvolva a atividade com mais eficiência, até o ponto em que o processo se torne uma extensão automática do pensamento, em forma de representação gráfica. É como o aquecimento realizado por esportistas antes dos jogos, se ficar muito tempo sem praticar o corpo esfria e requer um novo aquecimento.

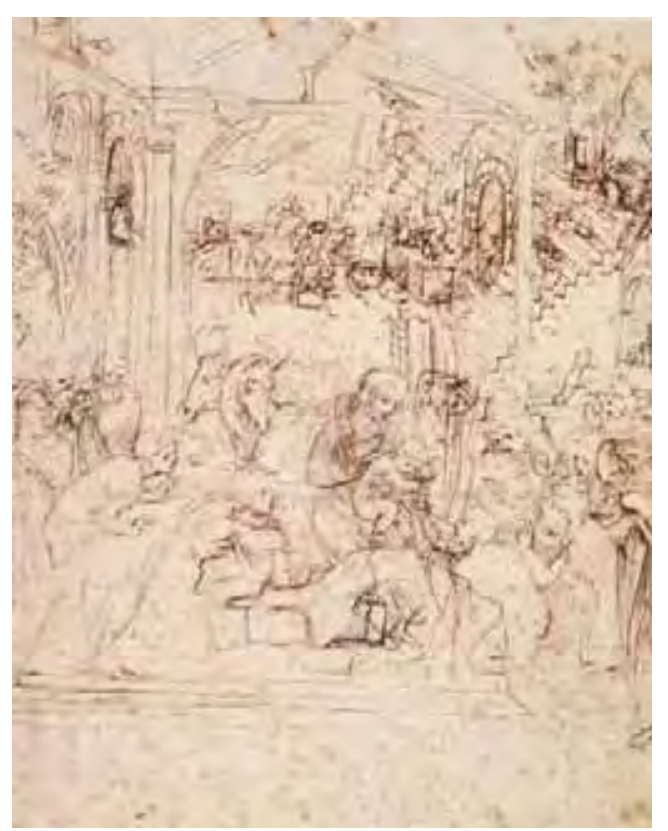

Figura 11.

Estudo de composição à pena e tinta sobre ponta metálica para "A Adoração dos Magos", de Leonardo da Vinci, 1481. Fonte: ZÖLLNER (2006, p.26)

Figura 12. Estudo de composição em perspectiva cônica, à pena e tinta sobre ponta metálica, para o plano de fundo de "A Adoração dos Magos", de Leonardo da Vinci, 1481. Fonte: ZÖLLNER (2006, p.27)

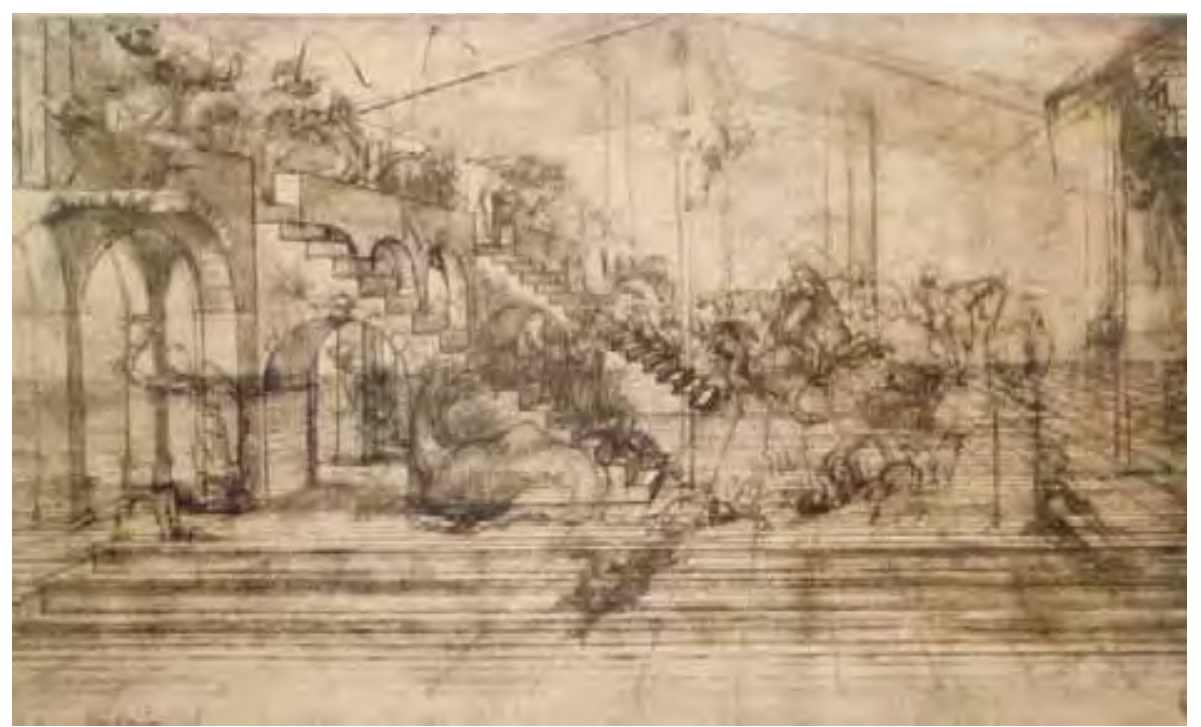


Chega-se num momento que o registro gráfico se torna a atividade de tradução do pensamento, onde um desenho expressional rejeitado, poucos dias depois de feito, pode não mais ser entendido ou interpretado pelo próprio arquiteto que o riscou (DINIZ, 2007). Sem a prática o processo pode se tornar vazio, mecânico, meramente operacional. "Sem um treinamento, um conhecimento do desenvolvimento de sua própria técnica de desenho, o profissional perde o poder de conhecimento e não consegue transmitir, com seus traços rápidos, a sua proposta" (PEREIRA et. al., 2005, p. 4)

O desenho-expressional é um recurso que se vale do desenho, do pensamento, de textos ou anotações, e de reflexões e interpretações que o cérebro faz com os estímulos de repertório, tanto memória quanto pesquisa; é um recurso gráfico rápido de planejamento, interpretação e conexão de informações diversas como forma de se chegar a soluções estimuladas pelas ideias.

Além da habilidade manual, Florio (2008) lembra do fator da incerteza que existe no ato criativo, pois são muitas as possibilidades, o que geram ansiedade em resolver o problema. O mesmo autor afirma que a incerteza está no cerne do processo criativo em projeto, estando muito mais presente na fase de criação, devido à falta de informações suficientes para resolver o problema, do que na fase de execução, onde a incerteza é reduzida, pois os objetivos já estão claros e as informações são suficientes para lidar com o problema. O mesmo autor afirma ainda que a incerteza é uma força-motora que impulsiona e origina múltiplas interpretações sobre o mesmo problema e que os desenhos de expressão são testemunhos desse momento de dúvida e insegurança quanto às escolhas que se apresentam.
"A sensação de bloqueio, ou de movimentação inútil sem progresso, às vezes é reflexo de um estágio natural e inerente ao processo criativo: a incubação. A angústia decorrente desse estágio, no entanto, pode ser encurtada e otimizada com as atividades de rascunhar, [...] alcançando-se o benefício adicional de treinamento da fluência gráfica e da capacidade de visualização espacial" (MEDEIROS, 2004, p.114).

Os desenhos de expressão, como registros preciosos do processo criativo, revelam a busca incessante da definição e solução de um problema ainda desconhecido. Por esses motivos alguns arquitetos não gostam de mostrar os desenhos dessa fase, pois estes revelam a incerteza e dúvida do processo decisório e expõem as dificuldades enfrentadas (FLORIO, 2008). Em outras palavras, o desenho expressional é uma forma de expressão humana que revela o criador e assim, a própria criação, por isso se justifica seu estudo como forma de entender e melhorar o processo criativo. 


\section{Desenho expressional e suas transformações}

No desenho expressional, os desenhos diferenciam-se de acordo com vários fatores mas em especial, de acordo com suas transformações, que podem ser quanto ao enfoque ou quanto ao refinamento da idéia, também conhecidas como transformações laterais e verticais (MEDEIROS, 2004), respectivamente. No primeiro caso, as transformações demonstram a busca pela forma mais apropriada, é a escolha da idéia, podendo ocorrer mudanças no ângulo de visualização e nas dimensões do motivo a ser desenhado. No segundo caso a transformação ocorre na idéia escolhida, dando-se destaque para melhor visualização, através de acabamentos à base de luzes e sombras, repetição e ou reforço no traçado, inclusão de cores, etc.

As transformações de refinamento são executadas ainda hoje, e em grande parte, até há pouco tempo atrás, com auxilio de mesas de luz, desenvolvendo-se novos desenhos mais refinados em outras folhas. Hoje, as transformações de refinamento, são muito auxiliadas pelo computador, já que é muito fácil obter uma nova cópia do desenho e executar o refinamento sem comprometer o original. 


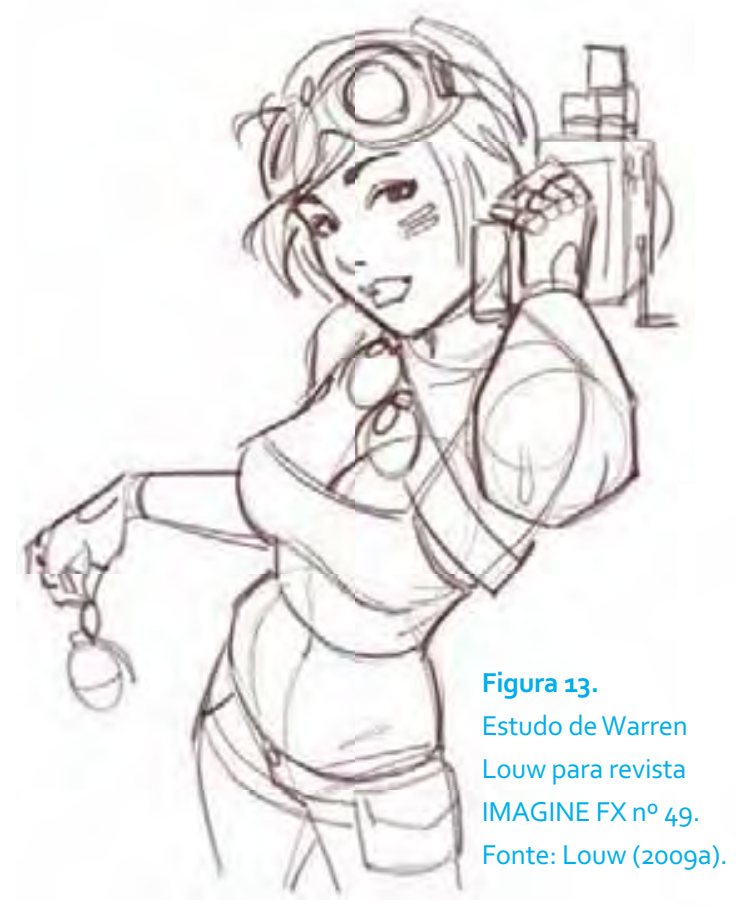

As imagens das Figuras 13 a 15 ilustram parte do processo do artista Warren Louw no trabalho realizado para a revista Imagine FX. Da Figura 13 para a Figura 14 pode-se perceber a mudança de enfoque, já bastante refinada (provavelmente devido à fluência gráfica do artista), onde evidencia o estudo de ângulo da composição. Depois dessa etapa foram realizados somente transformações de refinamento até a versão final [Figura 15].
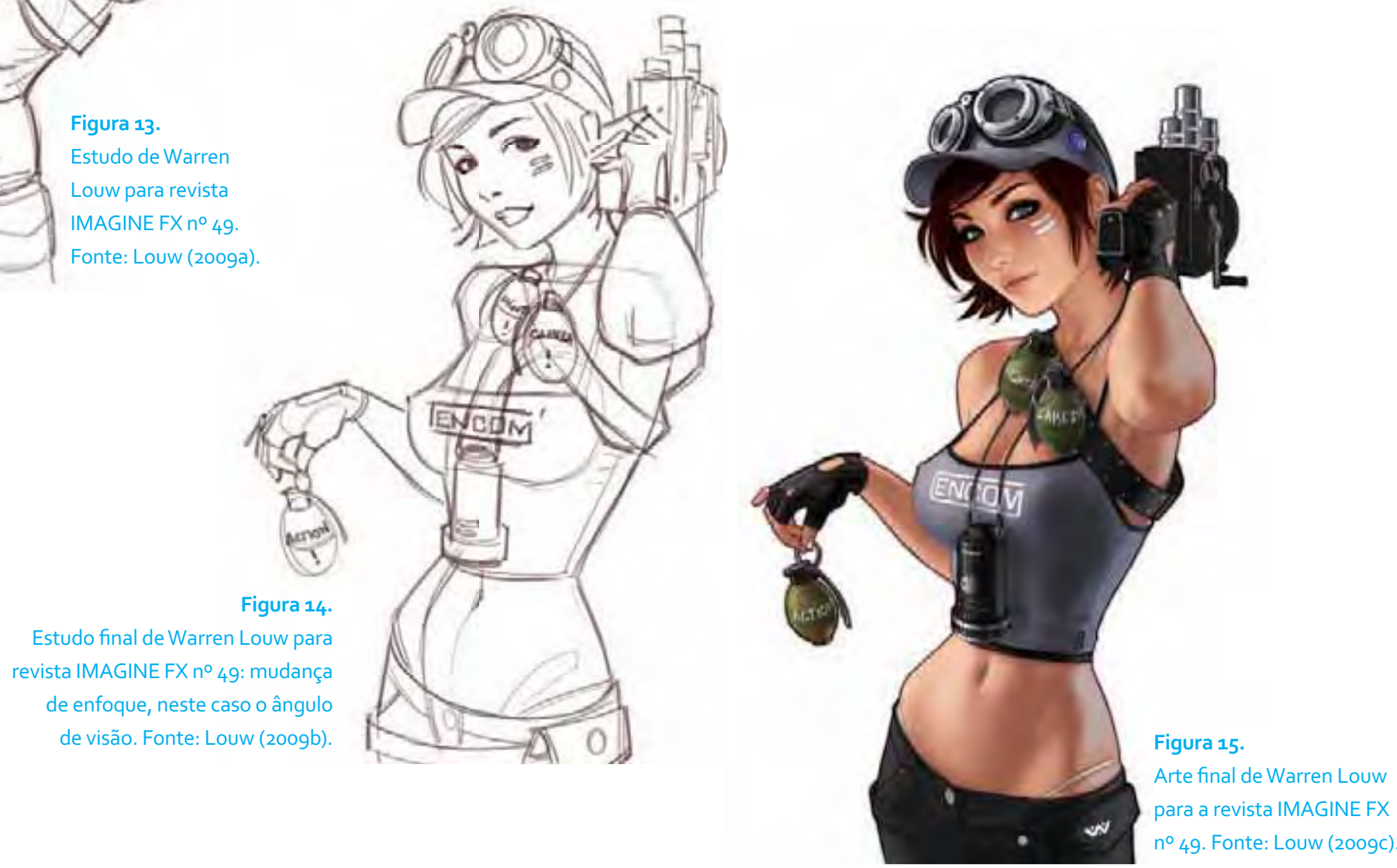
Neste caso o artista não contemplou os estudos anteriores ao primeiro desenho [Figura 13], e todo o processo criativo que o levou a esse mesmo desenho. De um modo geral, os estudos preliminares anteriores a essa fase são comumente descartados, como se não fossem importantes no processo. Isso ocorre de maneira semelhante no ensino onde há uma classificação quase que involuntária e automática entre desenhos "certos" e "errados". No desenho expressional não existe certo ou errado, existem transformações, que dependem de várias implicações: aquecimento motor, repertório, pesquisa, estados emocionais, materiais empregados, ambiente de trabalho, etc., que contribuem para a fluidez dos desenhos.

Muitos conhecem a obra "A Última Ceia", de Leonardo da Vinci [Figura 16], porém poucos já viram os primeiros estudos realizados para essa obra [Figura 17] e todos os outros estudos realizados com mais precisão [Figuras 18, 19 e 20].

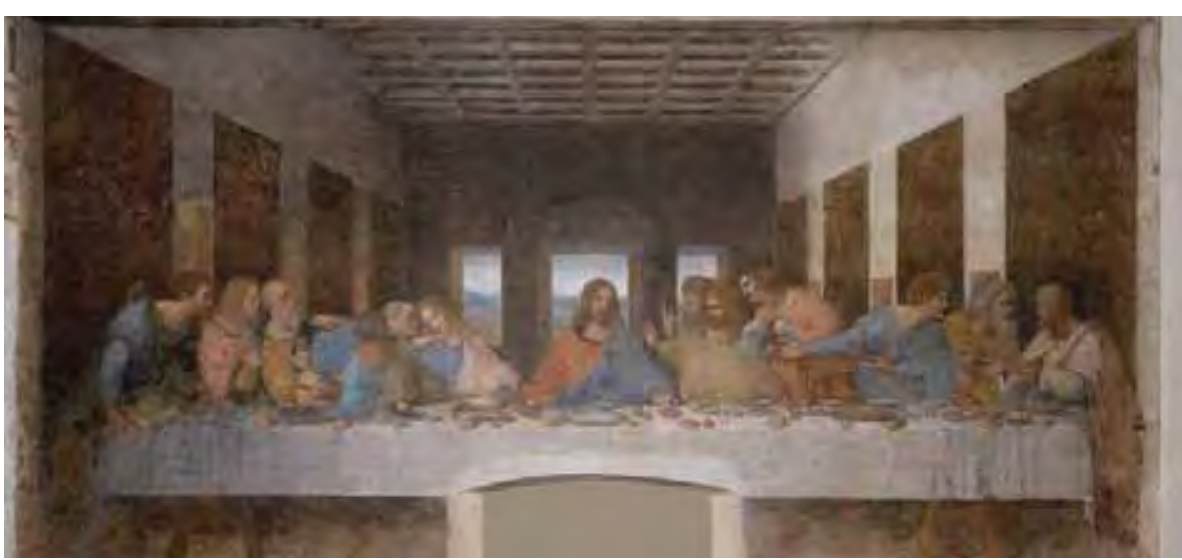

Figura 16 A Última Ceia, à óleo e têmpera sobre gesso, de Leonardo da Vinci (cerca de 1495-1498). Fonte: Zöllner (2006, p. 53)

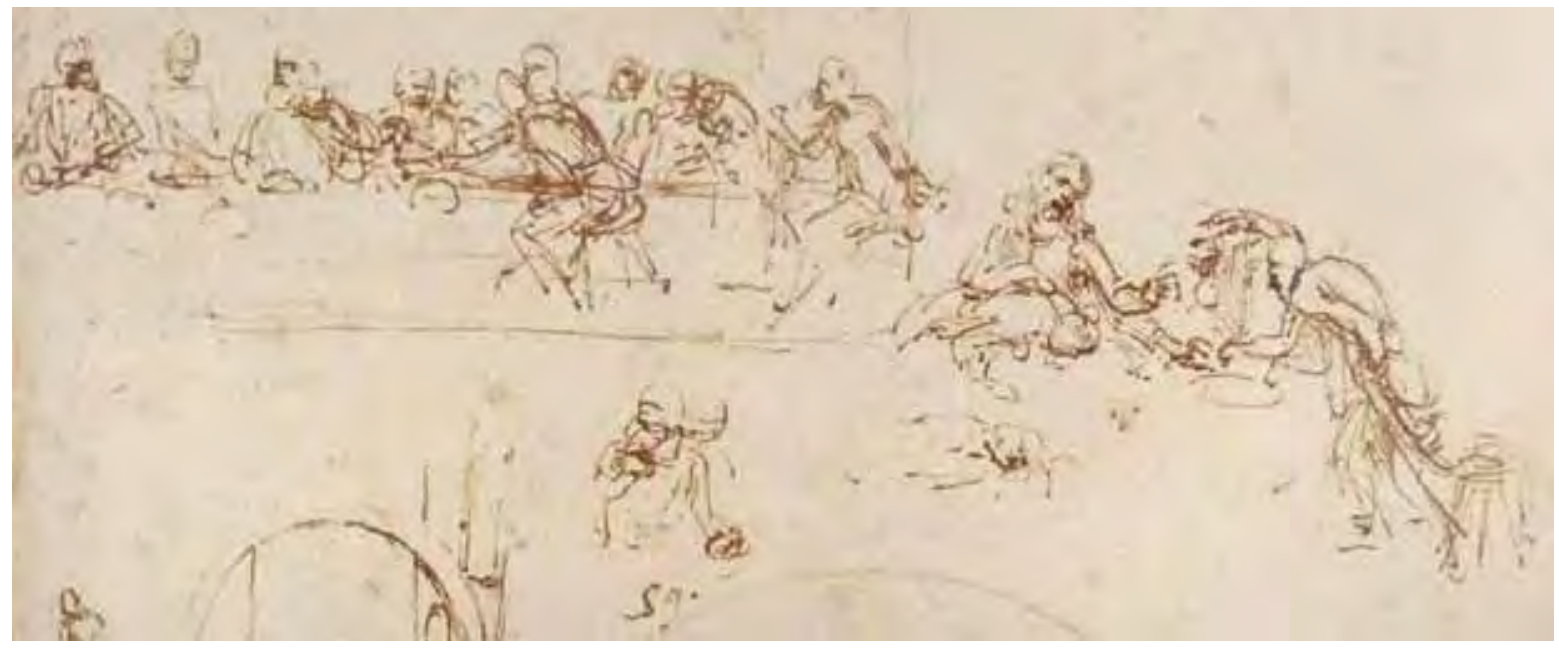

Figura 17.

Primeiro estudo para A Última Ceia,

à pena e tinta, de Leonardo da Vinci (cerca de 1495). Fonte: Zöllner (2006, p. 50) 


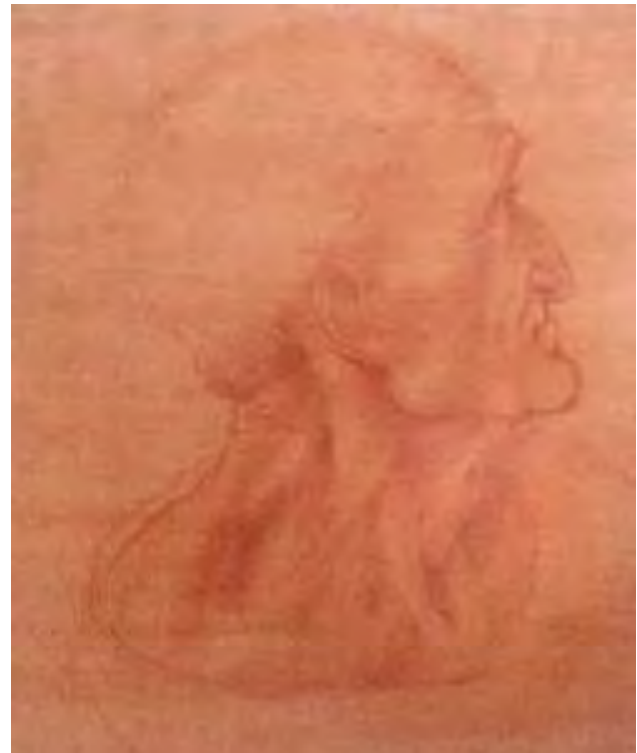

Figura 18.

Estudo para A Última Ceia

(Judas), à sanguina sobre papel

avermelhado, de Leonardo

da Vinci (cerca de 1495).

Fonte: Zöllner (2006, p. 56)

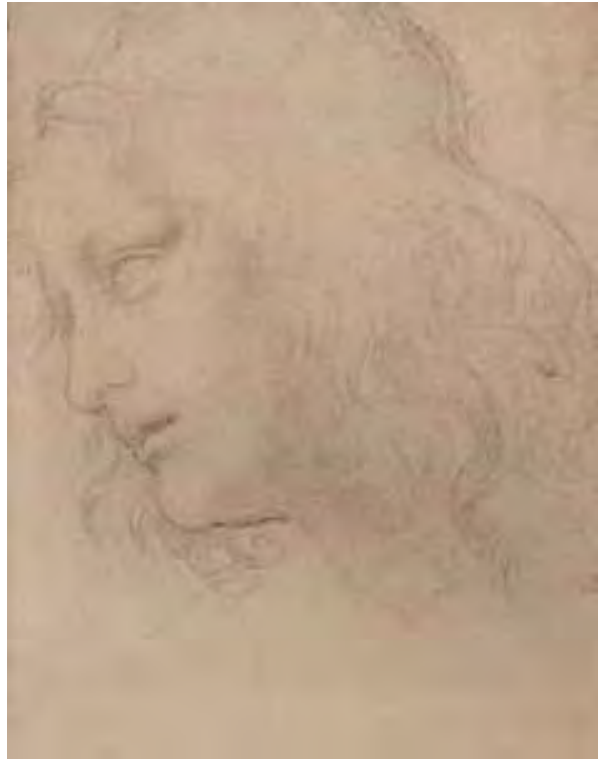

Figura 19.

Estudo para A Última Ceia (S.

Filipe), à giz preto, de Leonardo

da Vinci (cerca de 1495).

Fonte: Zöllner (2006, p. 57)

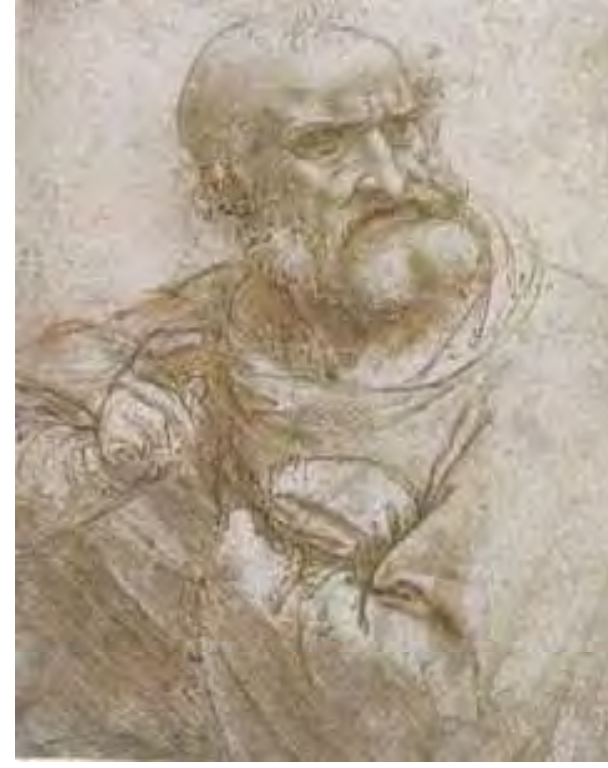

Figura 20.

Estudo para A Última

Ceia [Pedro?], à giz preto,

de Leonardo da Vinci

(cerca de 1495). Fonte:

Zöllner (2006, p. 58)
O desenho da Figura 17 é um dos desenhos de expressão que é comumente ignorado como forma de divulgação ou apresentação do processo criativo, pois revela um grau de refinamento quase nulo, mas ao mesmo tempo é rico em expressividade e que valoriza a busca e a investigação por uma solução, fugindo da obviedade que poderia ser proporcionada por um desenho já mais refinado logo de início.
Do lado oposto à utilização do desenho expressional, existem exemplos de trabalhos realizados sem o uso desse recurso. Este fato pode ser explicado pelo fator de inovação ou originalidade envolvido no projeto, que pode ser: 
Projeto original é aquele que envolve elaboração de solução inédita. Pode derivar numa inovação radical por modificar significativamente o que existia em determinado mercado em termos de produto ou processo. O projeto adaptativo implica em ajuste de sistema já conhecido para nova tarefa ou exigência do mercado. Consiste em adequar princípios de solução conhecidos, incorporando a eles melhorias incrementais. A ênfase em geral recai sobre questões de forma, de desempenho, de produção e de material. O projeto rotineiro é aquele que requer mudança de tamanho ou rearranjo no produto de maneira a agregar melhoria àquilo que já existe. Exemplos disso são mudanças em materiais ou componentes do produto, alterações morfológicas que acarretam redução nos custos de fabricação, distribuição, estocagem, descarte, etc. (PAHL e BEITZ apud MEDEIROS, 2002, p. 7)

Dessa forma, entende-se que a necessidade de utilização do desenho expressional pode estar vinculada com a originalidade do projeto. No caso de projetos que são pura cópia de uma referência, ou mesmo baseados em modelos (templates) e não envolvem nenhuma inovação, a necessidade de uso do desenho expressional fica atrelada apenas à habilidade do criador na ferramenta utilizada. Neste caso diminui-se em grande parte a reflexão sobre o problema projetual.
Hoje em dia é comum que os designers realizem grande parte das pesquisas para suas criações na rede mundial de computadores interligados, a internet. Porém, com o acesso fácil a todo tipo de informação, parece haver uma tendência na criação de ideias não tão originais. Neste sentido, a internet funciona como uma grande ferramenta de disseminação de mesmas ideias. Um dos resultados disso é o uso indiscriminado de modelos sem muito critério onde conceitos importantes são deixados de lado empobrecendo o projeto. Uma busca vazia por imagens na internet, ou seja, sem conceitos pré-estabelecidos, só conduz à perda do poder de investigação que pode ser incentivado pelo uso do desenho expressional. 


\section{Cadernos de rascunhos}

O designer pode desenvolver habilidade para imaginar um produto pronto, acabado, inteiro. Já enxergar o projeto como um todo, com todos os seus detalhes é uma tarefa que exige muito intelecto. E a memória é efêmera, portanto pode não dar conta de todos os detalhes de um projeto. Por isso, antes de mais nada é preciso o seu registro:

“A ação de representar, no papel, pensamentos provisórios e incompletos sugere que a função do 'caderno de rascunhos' seja armazenar lembranças, como estratégia para superar as limitações da memória de curto prazo, que lid ativamente com somente um reduzido numero de itens [...] A memória de curto prazo é o principal processador de informação do cérebro, mas não retém informação, a não ser que o estimulo seja reforçado por auxiliares de memória" (MEDEIROS, 2004, p.48). 
Mesmo que a memória pudesse dar conta de todos os detalhes e pormenores do projeto, ainda assim, estaria se estimulando demasiadamente um só tipo de percepção: a intelectual e diminuindo ou limitando as possibilidades de soluções do projeto a partir de outros estímulos exteriores. Acredita-se que a qualidade do projeto deriva também da conciliação das relações, interpretações e percepções em torno do problema. Assim, o registro das ideias deve existir e ser um ato mais instantâneo possível, para que as ideias não caiam no esquecimento. Para isso, é importante ter condições que favoreçam o seu registro e um mínimo de recursos devem estar disponíveis para melhor eficiência nessa relação.

O computador também pode ser utilizado como ferramenta para registro e organização das ideias, porém depende de muitos recursos para sua execução: domínio de software, botões, interface, sistema operacional, tela, teclado, mouse, energia elétrica, ambiente, postura. No lápis e papel os recursos são mais simples e consequentemente mais ágeis e eficientes. Já as habilidades mentais (ideias) e manuais (ferramentas) são necessárias em ambos os casos.

Qualquer interrupção na interação da idéia com seu registro pode ser prejudicial ao processo criativo. Existem diversos tipos de suporte que podem servir para registrar uma idéia. Entretanto, há aqueles que são mais apropriados para essa tarefa.

Os 'cadernos de rascunhos', ou sketchbooks, são suportes utilizados pelos criadores para conter os registros de suas ideias. Normalmente são cadernos sem pauta, com formatos, papéis, texturas, cores e gramaturas diferenciados. De modo geral, são mais apropriados para receber o traçado do desenho expressional, por isso alguns possuem folhas mais espessas, para conter o traçado mais expressivo, enérgico e muitas vezes espontâneo.

Um caderno de rascunhos bastante conhecido é o de Leonardo da Vinci, que evidenciava suas reflexões sobre estudos de arte, arquitetura, engenharia, medicina [Figura 21], etc.

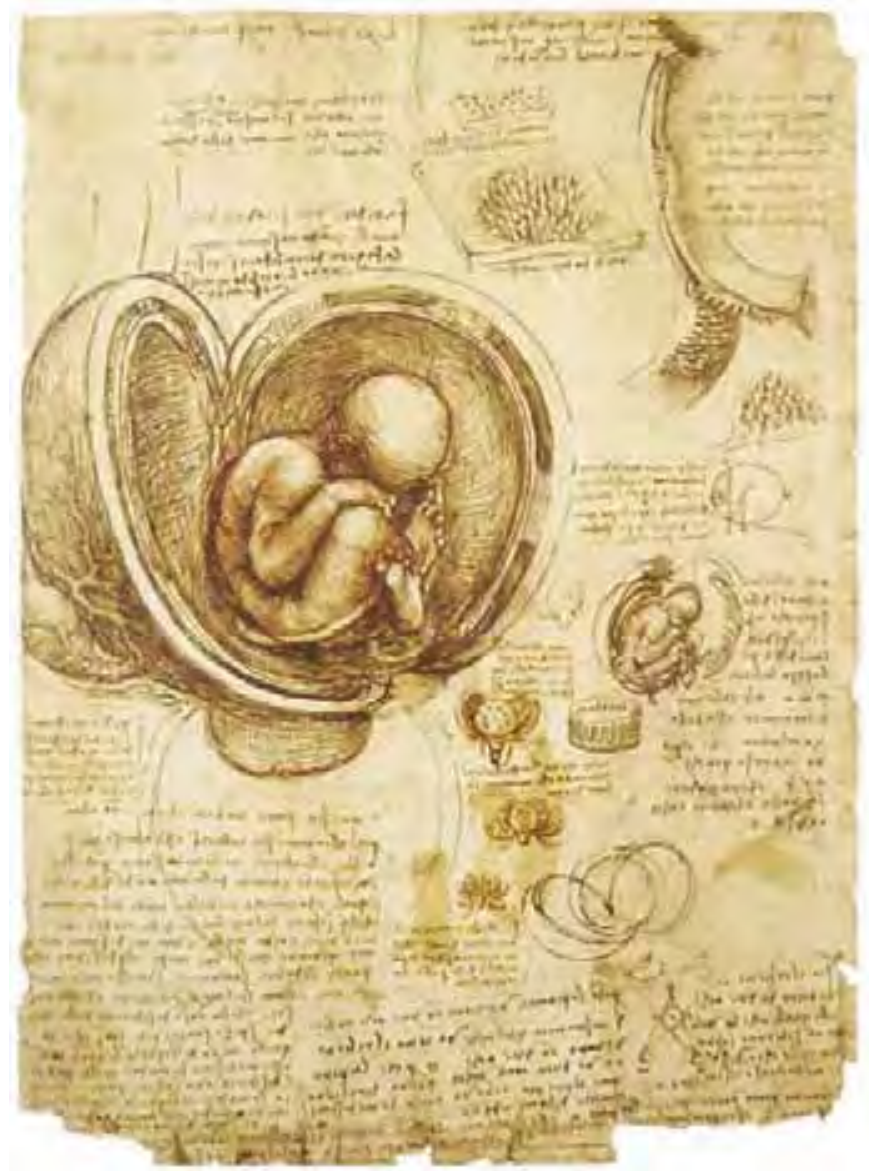

Figura 21.

Anotações de anatomia sobre "O

Feto no Útero", de Leonardo da Vinci (cerca de 1510-1512). Pena e tinta com aguada sobre giz preto e vermelho. Fonte: Zöllner (2006, p.82) 
O hábito de se usar caderno de rascunhos não é muito comum no Brasil. Em países estrangeiros existem empresas que fabricam esses cadernos e até editoras especializadas em publicar os desenhos de expressão desenvolvidos por artistas mais consagrados [Figura 22].

O designer Rex Crowle fez vários estudos para criação de personagens da série Grip Wrench [Figura 23]. Ele cita que a baixa qualidade do papel e mesmo alguns campos impressos na folha favorecem o seu registro, evitando que ele tenha que começar um desenho na folha em branco (COMPUTER ARTS, 2009). Esse fato exemplifica como o próprio papel em branco pode impor níveis de precisão que não são adequados para o desenho expressional, é a ansiedade com que os criadores se deparam antes do ato criativo. Portanto o rigor, ou a exigência de uma "etapa" para criação, com lápis e papel branco na mão, pode não ser o melhor caminho para sua execução. Do lado inverso à esse rigor, existe aquele registro que é feito como resultado espontâneo das relações que o cérebro faz e um suporte mais "tosco" pode ser mais apropriado.

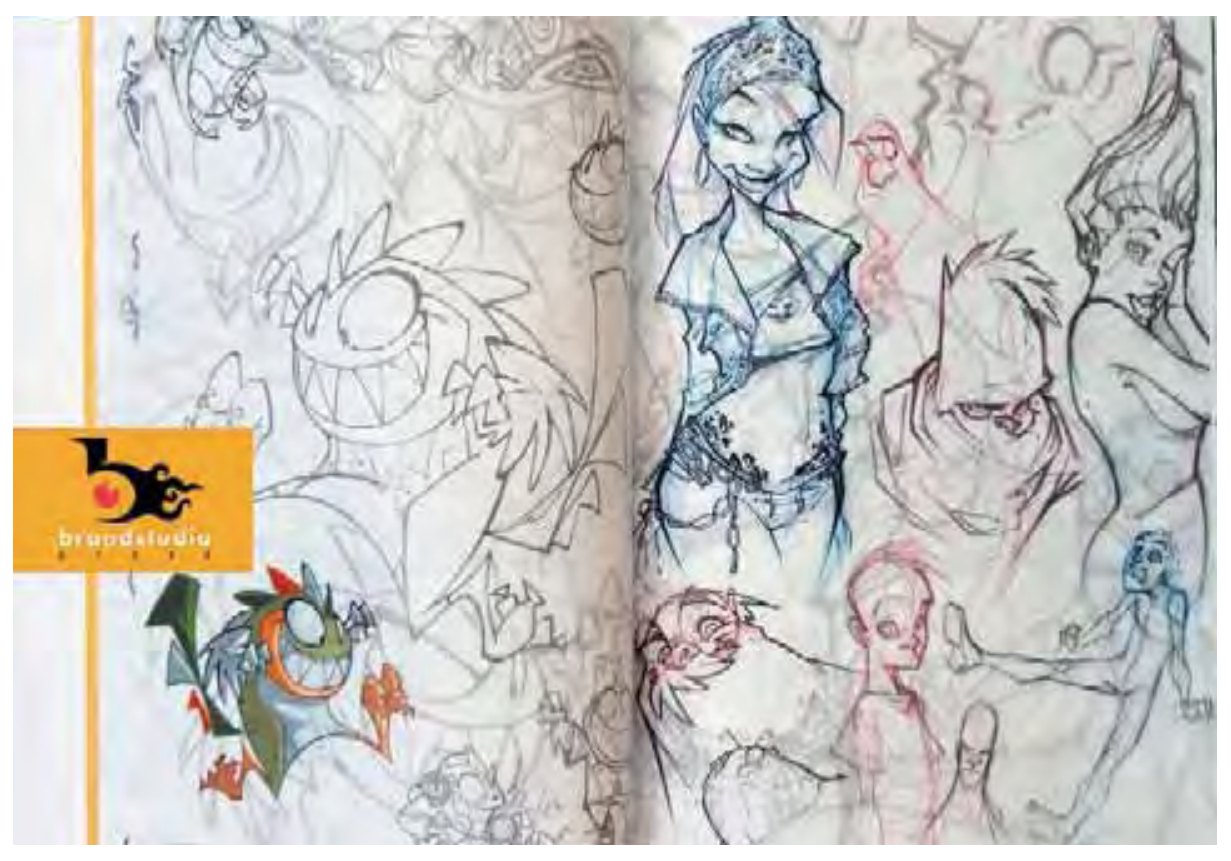

Figura 22. Página de livro de sketchbook do artista Francisco Herrera. Fonte: herrera2_04_big.

jpg (s.d.). 


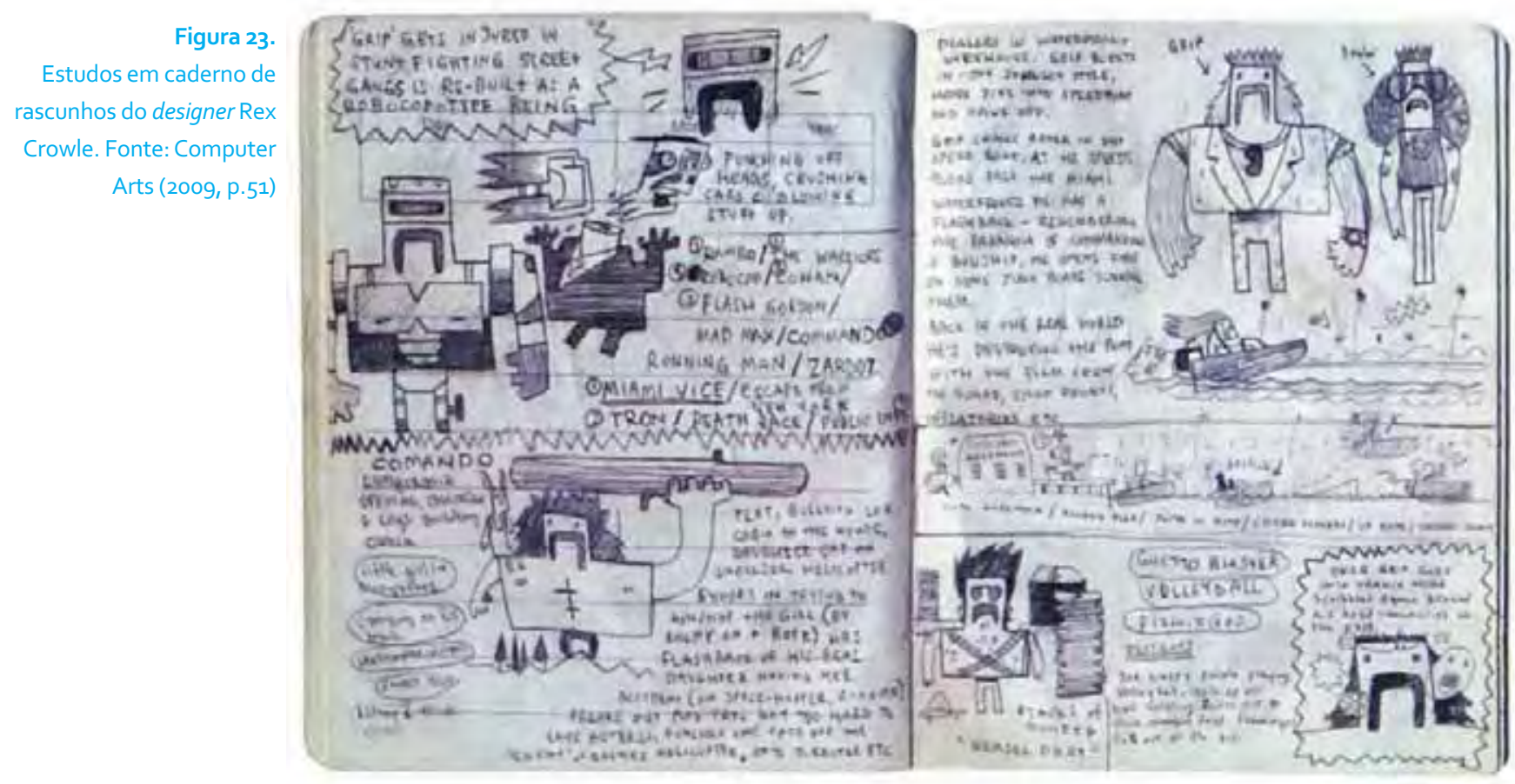

Para se habituar a fazer desenhos de expressão, professores de disciplinas projetuais poderiam adotar blocos de anotações não pautados como material básico para seus alunos, que o utilizarão durante o ano letivo em seus projetos como forma de deixar as idéias fluirem naturalmente, sem pretensão de julgamento, apenas como forma de extrair e explorar de forma gráfica as idéias que se apresentam, espontâneas ou não.
O hábito de praticar o desenho expressional poderia ser incentivado desde os primeiros anos educacionais, mas é limitado pela estrutura tradicional do ensino público brasileiro, no qual se utiliza de cadernos pautados para composição de textos logo nos primeiros anos de alfabetização. Se o aluno já é limitado a executar a grafia de textos e anotações em cadernos pautados, força-se uma composição da grafia de forma pré-definida, que acaba ignorando sua individualidade, sua liberdade de expressão e sua capacidade de composição de informações na página. Nesse sistema tradicional de ensino o aluno é dado como incapaz de escrever em linhas retas sem uma pauta. Portanto o estímulo para o hábito da expressão gráfica requer repensar sua prática em vários âmbitos do ensino. 


\section{Desenho expressional e organização de ideias}

Todo projeto sempre deve caminhar do geral para o particular; de aspectos ou relações globais para aspectos ou relações específicas sobre um problema. Se não for por esse caminho, os riscos de erros ou deficiências no projeto são bem maiores. Por exemplo, todo projeto de informações e conhecimentos que servirão de base para seu desenvolvimento. Se no decorrer do projeto, uma dessas informações básicas estiver errada, pode ocasionar uma alteração em todo o processo, obrigando o designer a voltar algumas etapas talvez até ao início se for o caso; a menos que o projeto não tenha nenhum propósito de "dar certo", ou de funcionar, ou também no caso do método de "tentativa e erro"; ele deve contemplar informações, de repertório do indivíduo criador e de pesquisas em torno do problema, informações que indicarão caminhos a serem percorridos. 
Esse pressuposto pode ser confirmado a partir da evolução dos métodos adotados em metodologia projetual do design onde a pesquisa, a transdisciplinaridade e a usabilidade, têm ganhado cada vez mais espaço e importância no processo. A evolução desses métodos convergem para um mesmo ponto: maior aquisição de conhecimentos e informações e consequentemente mais pontos de vista sobre um mesmo problema. Ou seja, ampliar o repertório (racional e emocional) como forma de gerar soluções mais precisas, ou mais maduras. É uma visão geral, ampla, em direção a uma visão específica - o produto ou solução. É uma lógica que ajuda o projetista a organizar e focar o problema do projeto.

Assim como o rascunho de um texto, o desenho-expressional serve para estruturar o esqueleto de um projeto. Enxergar o problema sob aspectos gerais (enxergar ou focar o todo) para só depois ir detalhando (enxergar ou focar as partes). Através do desenho expressional o projetista tem um instrumento para se prender à solução de conjunto (visão geral), que é indispensável, segundo Niemeyer apud Diniz (2007)(Anexo E). Ao analisar a vida de Niemeyer em sua atuação profissional é inevitável a comparação: ao que parece, a evolução do profissional que lida com criação tende para a fase de produção de desenhos expressionais, enquanto que a parte de produção/execução/desenho técnico/refinamento fica a cargo de outros profissionais menos experientes.

Além dessa evolução nas metodologias projetuais, várias pesquisas sobre os processos de projeto indicam uma tendência (provavelmente até influência das metodologias), dos projetistas caminharem no sentido de relações globais para relações específicas:
“Os projetistas têm uma tendência geral, independente da mídia, de resolver o problema de planejamento do espaço começando pela divisão do layout das áreas (relações globais) e depois abordando as relações locais entre os componentes." (CARVALHO et al, 2005).

"A arquitetura [...] nasce sempre de uma visão geral. Essa primeira imagem é aquela que surge logo nos seus primeiros esboços e dificilmente ele modifica substancialmente esta ideia inicial, depois dela se desenvolve todo o ato de projetar." (ROSSI apud DINIZ, 2007)

"O arquiteto modela o espaço como o escultor modela a argila, desenha-o como obra de arte. Quando um arquiteto projeta um edifício depois de ter tomado uma decisão sobre as formas principais, a largos traços, ele prossegue adicionando detalhes que brotam como botões e espinhos." (RASMUSSEN apud DINIZ, 2007).

Não se defende aqui um método linear ou preciso de resolução de problemas, partindo-se do geral para o particular. A preocupação nesse momento é elucidar como as evoluções a respeito das metodologias têm indicado essa necessidade de se abrir o leque para depois se fechar. Tanto que, o projeto e mesmo as ideias podem ser desencadeadas a partir de algum detalhe. A partir desse insight, o leque se abre reunindo e incorporando outras informações para depois se afunilar novamente no desenvolvimento do projeto. O processo é também cíclico e mesmo partindo de uma idéia específica sobre o problema, ele precisa ser visto como um todo para gerar soluções eficientes e maduras; soluções que não sejam egocêntricas. 
As primeiras ideias, ou achismos, tendem a ser espontâneos, mas ao mesmo tempo egocêntricas, pois podem não valorizar, a princípio, outros pontos de vista. Por isso, é importante a pesquisa para o desenvolvimento de novos produtos, de forma que estes (as soluções) surjam da investigação concreta das necessidades dos usuários e da identificação do verdadeiro problema de projeto e não somente de puros "achismos" (FRISONI e RODRIGUES, 2003), entendidos aqui como ideias prontas, ou primeiras ideias, primeiras relações, primeiros insights. Porém, "mesmo os insights necessitam de gerenciamento e fundamentação para que sejam explorados e não se constituam em vontade pessoal" (FRISONI e RODRIGUES, 2003, p.7). Significa testar, ou colocar à prova, a idéia ou solução do projetista.

A solução de um projeto também vai sendo lapidada à medida que são incorporadas informações às ideias, quer seja através da exteriorização de um pensamento num diálogo, onde outras pessoas com outras opiniões discutem uma idéia, quer seja pela análise a partir de pontos de vista diferentes em torno do desenho-expressional. E essa lapidação muda a relação do projetista com o produto e com o projeto.
O desenho expressional é a representação gráfica em traços gerais das ideias que vão sendo lapidadas até se tornarem mais claras (MONTENEGRO, 2007); portanto, essa "lapidação" é um ajuste que se dá àquilo que está sendo trabalhado. É um exercício de reflexão, de "pensar sobre o que está se fazendo", de refletir sobre as ideias gerais, ou os problemas e funções gerais que precisam ser detalhados até se chegar a uma solução de projeto. As ideias específicas, detalhes ou acabamentos, são processos secundários dentro de um projeto, que podem ser trabalhadas com instrumentos de maior precisão como o computador, por exemplo.

Portanto o desenho-expressional está diretamente ligado ao ato de investigação sobre determinado problema. São registros e anotações que incitam o ato de pensar, de planejar, de procurar alternativas. Esse tipo de desenho pode auxiliar no processo de enxergar o problema e de organizá-lo de forma produtiva, eficiente, a fim de se evitar o modo empírico de resolução, mas apoiado em um processo que já se mostrou eficiente, apesar de suas limitações e que vem sendo atropelado pela falsa idéia de que através do computador pode-se resolver tudo. 
A atividade de desenvolvimento de um novo produto não é simples e nem direta. Ela requer pesquisa, planejamento cuidadoso, controle meticuloso e, mais importante, o uso de métodos sistemáticos. Contudo, utilizar métodos sistemáticos não significa trabalhar em linha reta ou subir um degrau de cada vez. É necessário uma visão panorâmica de todo o processo e ter noção que em determinados momentos existe a necessidade de retorno, tornando o método além de sequencial, cíclico (BAXTER apud FRISONI e RODRIGUES, 2003). Essa colocação é reforçada com Perrone et. al. (s. d.) ao afirmar que o processo de projeto é claramente não linear, embora buscando uma aproximação sucessiva ao objeto, os arquitetos ziguezagueiam entre soluções e alternativas. O desenho expressional de projeto é dinâmico, não é um fim em si. Novas soluções podem se desencadear no cérebro em momentos diversos do projeto. Assim, pequenos desenhos de expressão podem se tornar necessários em vários momentos do processo de projeto. O mesmo autor completa que os diversos momentos em que os desenhos de expressão atuam no projeto também foram detectados, incluindo-se participação desde a concepção da obra até detalhamento de pormenores.
O uso do desenho expressional em várias fases do projeto também é citado por outros autores. Munari (1981) coloca que esses desenhos servem para comunicar uma forma ou função ou para dar instruções acessórias durante os trabalhos dos modelos ou dos pormenores construtivos. O autor coloca ainda que os desenhos de expressão podem servir ainda para anotar como pró-memória algo que tenha em mente, que descobriu, que quer modificar. São portanto, anotações que estão presentes em várias fases do projeto, mesmo nos modelos e acabamentos.

É inevitável que surjam ideias logo que se depara com um problema, pois já se possui um repertório. Essas primeiras ideias são muito espontâneas. São importantes e precisam ser registradas para depois serem interpretadas, julgadas, confrontadas e amadurecidas com outras ideias adquiridas da pesquisa. As metodologias lineares que colocam a criatividade como uma etapa, e ainda posterior à pesquisa, podem estar formatando demais as ideias criativas, gerando soluções operativas, mecânicas.

Essas primeiras ideias devem ser registradas porém não devem ser encaradas como a melhor ou única solução para o problema. Segundo Munari (1981), o designer não deve ir imediatamente à procura de uma idéia geral que logo resolva o problema, porque é o método artístico-romântico destinado a arranjar soluções. A primeira coisa a fazer é definir o problema no seu todo, que servirá também para definir os limites dentro dos quais o projetista deverá trabalhar. 
As ideias vêm e vão em frações de segundo, o cérebro faz relações o tempo todo e elas ficam incubadas no inconsciente. São relações e conexões de informações contidas em nossa memória a qual é capaz de armazenar muitas informações, porém reuni-las, organizá-las e apresentá-las conscientemente de maneira clara é um processo de comunicação que nem sempre é tão eficiente. É importante saber filtrar as informações que são relevantes ao projeto, pois é muito fácil se perder em detalhes antes de se enxergar o problema como um todo. Além de experiência, é necessário ter percepção. Com a explosão da informação, a exigência para compreender tudo o que se recebe leva à ansiedade de informação, o buraco negro que existe entre dados e conhecimento, e ocorre quando a informação não diz o que se quer saber; para que se diminua esta ansiedade, é preciso determinar o que é realmente relevante para o trabalho (WURMAN apud GÓMEZ et. al., 2008).

Para se determinar o que é realmente importante são necessárias análises, percepções, estudos, planejamentos, experiência. No que diz respeito aos estudos ou planejamentos visuais, o desenho-expressional pode auxiliar nesse processo:

"O recurso aplicado em nosso trabalho de ferramenta gráfica esboço-croqui, tem como finalidade organizar raciocínios, fatos, constatações, estudos, percursos e fases de trabalho. Refletindo sobre o que vê, o observador registra o que compreende da realidade e o julga ser digno de interesse" (PEREIRA et.al., 2005, p. 3).
O desenho-expressional é uma maneira de se avaliar uma idéia sem que ela exista materialmente; avaliar através da percepção visual, de maneira rápida, sem acabamento, é um teste onde se faz escolhas e dá-se o detalhamento/acabamento somente àquela solução que se mostra ser a mais conveniente. E é claro que o ato de pensar e refletir pode percorrer todo o processo, assim podem haver modificações no meio do processo - pequenas alterações à medida que o produto se torna mais claro e perceptível. Se houver a necessidade de grandes alterações lá na frente, é porque as informações reunidas no início do projeto não foram suficientes ou não abordaram muitos pontos de vista (visão ampla, do todo). 


\section{Desenho expressional e projetos}

Grande parte das publicações especializadas em comunicação visual não ilustra os estudos preliminares dos projetos desenvolvidos. Mesmo as que citavam a fase do desenho expressional não contemplavam seu registro. Dessa forma, houve certa dificuldade em encontrar evidências de projetos onde envolvessem efetivamente os estudos de concepção. Os exemplos aqui apresentados estão dispostos segundo uma definição básica de tipos de projeto em comunicação visual. Alguns se referem às fases mais iniciais de concepção, outros à fases mais avançadas e, em alguns casos não se teve acesso à arte final para comparação. Essa variação nas fases, entretanto, favorece sua análise, já que mostra as evoluções e transformações pelas quais cada projeto passou.

A tipografia é uma das bases da comunicação visual. Ao longo de sua história, o desenho de expressão sempre esteve presente no processo de concepção. Segundo Lupton (2006),

"A história da tipografia reflete uma tensão contínua entre a mão e a máquina, o orgânico e o geométrico, o corpo humano e o sistema abstrato. Essas tensões, que marcaram o nascimento das letras impressas há mais de quinhentos anos, continuam a energizar a tipografia hoje" (LUPTON 2006, p.13) 
Com a inserção da informática nesse processo, a função do desenho de expressão vêm sendo utilizada quase que da mesma forma como há centenas de anos atrás: com lápis sobre papel e, em alguns casos, ela está sendo até incorporada, e não abolida, pelos recursos computacionais. Farias (2001), descreve três softwares que servem para criação de fontes digitais. Em dois deles (Metafont e DAFFODIL) o software automatiza o processo de criação das letras a partir da definição de alguns caracteres fornecidos pelo criador. O outro software, chamado de LetterSpirit, "visa compreender os mecanismos da criatividade através da modelagem do processo de design de fontes tipográficas" (FARIAS, 1998, p. 38). Nele o processo criativo se divide em 4 módulos, dentre os quais há a função do "Desenhador"ou "Bloco de Rascunhos", ou seja, o software se utiliza de funções manuais na concepção dos tipos digitais.

Nas Figuras 24 e 25 estão alguns estudos para concepção de tipografias executadas no início da Revolução Industrial. Já a Figura 26 apresenta estudos para fim digital, realizados em guardanapo pelo designer Martin Majoor, em um trem que ia de Berlim a Varsóvia em 1996 (LUPTON, 2006).

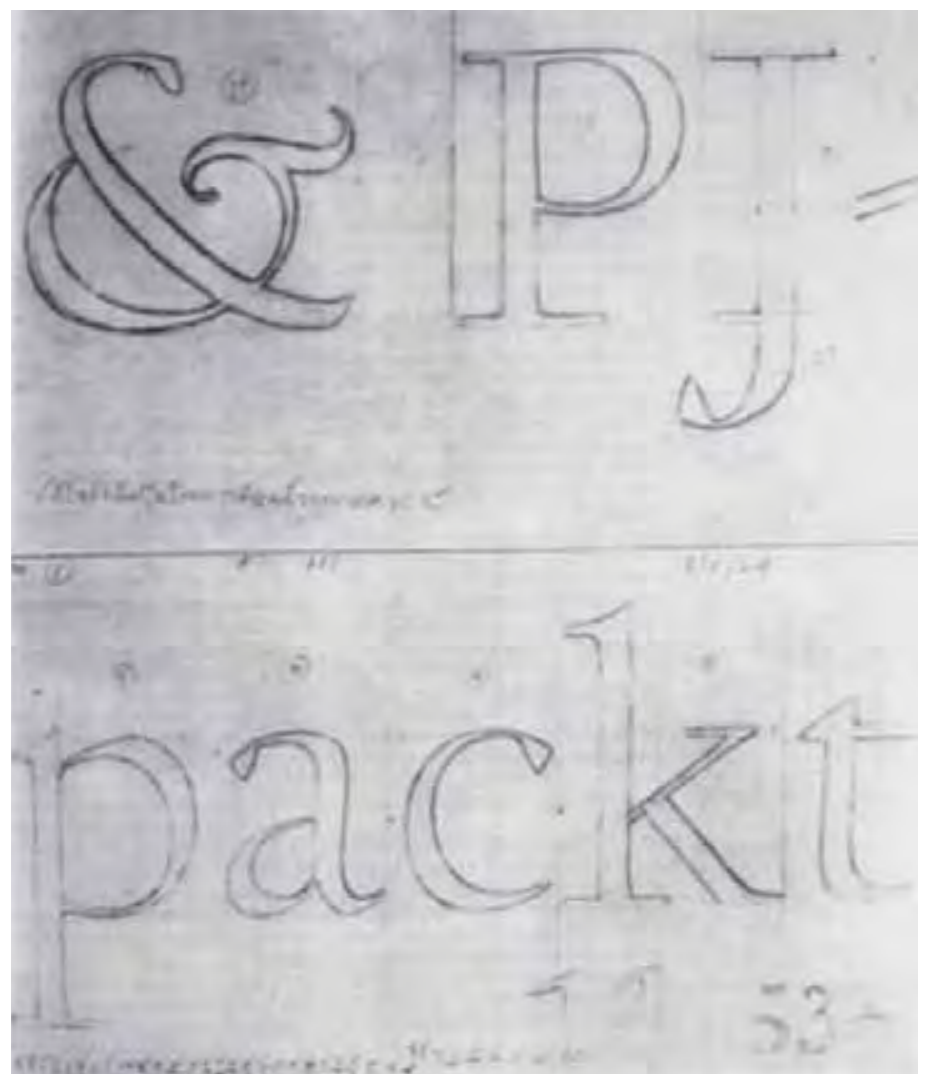

Figura 24.

Desenhos do tipógrafo

americano Frederick

W. Goudy (1865-

1947) para o tipo que

leva o seu nome.

Fonte: Haley (1992)

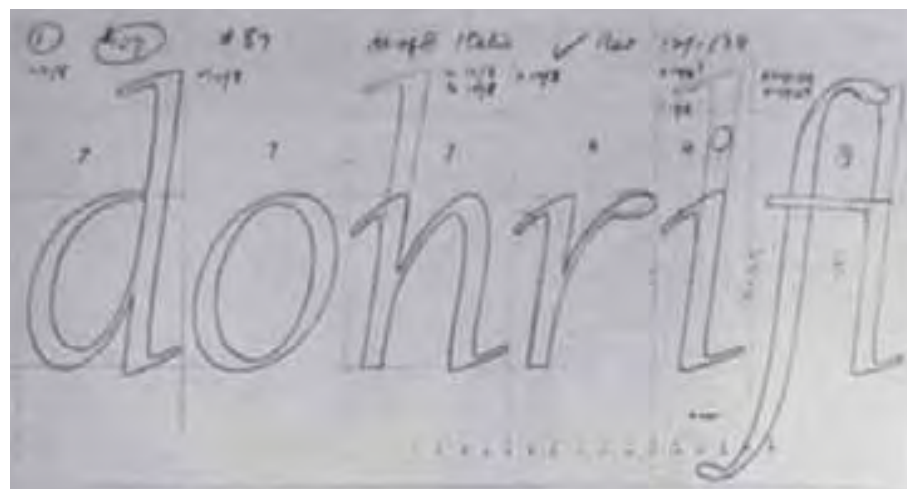

Figura 25 .

Desenhos de F.W.

Goudy para o tipo 'University California

Old Style' (1939).

Fonte: Haley (1992) 
No campo da identidade corporativa, os processos criativos passam a envolver aspectos mais abrangentes na projetação, como a escolha e composição de cores, por exemplo. Por isso a atenção e o respeito ao processo como um todo se tornam ainda mais necessários. A seguir alguns exemplo do processo para criação da identidade para Island of Bahamas [Figuras 27 e 28].

Conforme já foi mencionado, a utilização de desenhos de expressão colocados na parede para avaliação é uma tarefa habitual daqueles profissionais que reservam espaço para este tipo de investigação:

A criatividade anda por muitos caminhos. Em alguns escritórios vários designers trabalham na mesma idéia, enquanto em outros cada designer pode desenvolver uma idéia ou uma estratégia de posicionamento diferente. Rotineiramente, centenas de esboços são colocados na parede para discussão em grupo. Cada abordagem preliminar pode ser o catalisador de uma nova abordagem. A dificuldade é encontrar uma forma simples que seja forte, memorável e apropriada, porque vivemos e uma ambiente visual supersaturado, onde é fundamental assegurar que a solução é especial, única e diferenciada. Além disso, uma identidade precisa ser um cavalo de batalha em varias mídias e aplicações (WHEELER, 2008, p.114).

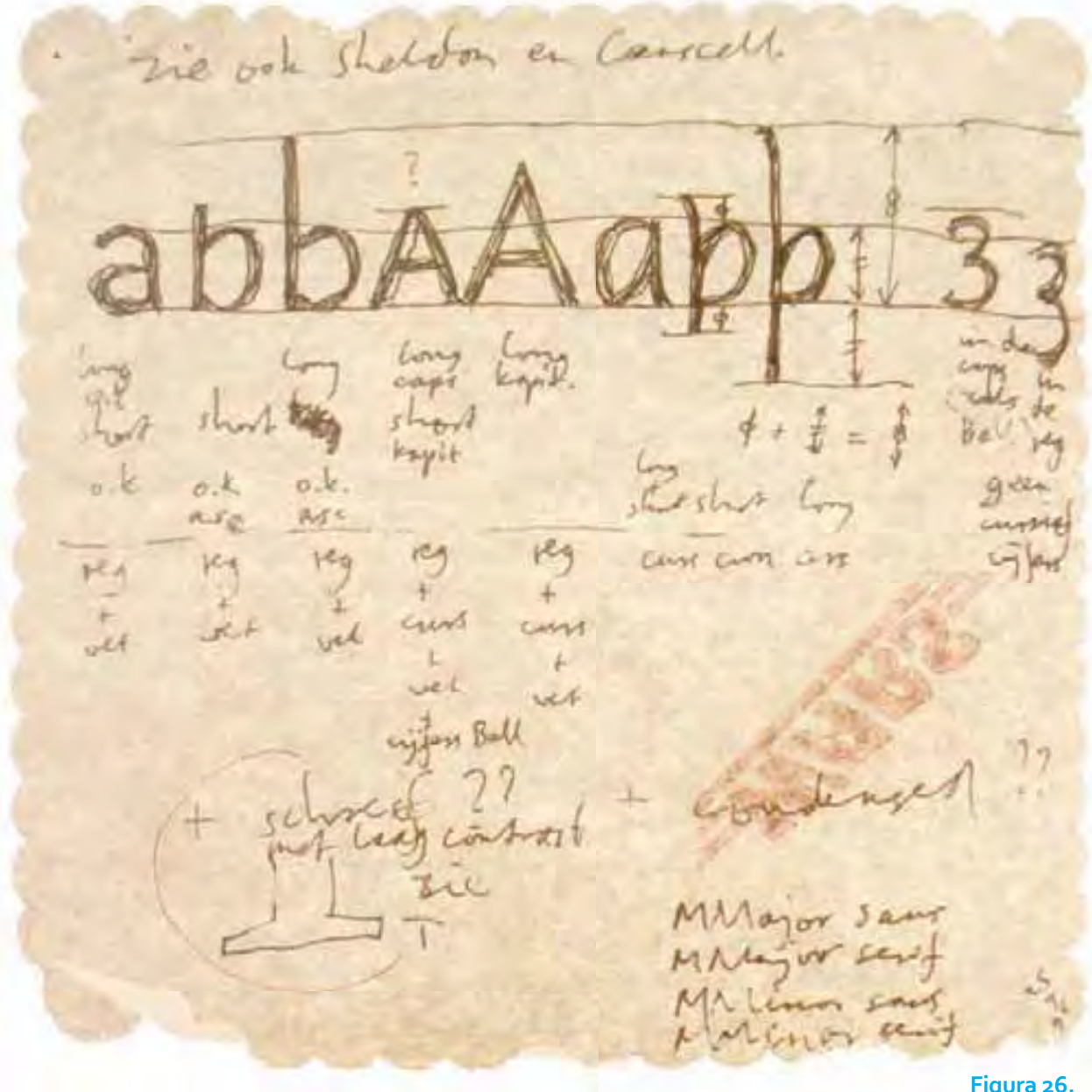

Figura 26. Estudos de Martin Majoor para a fonte Seria, Fonte:

Lupton (2006). 

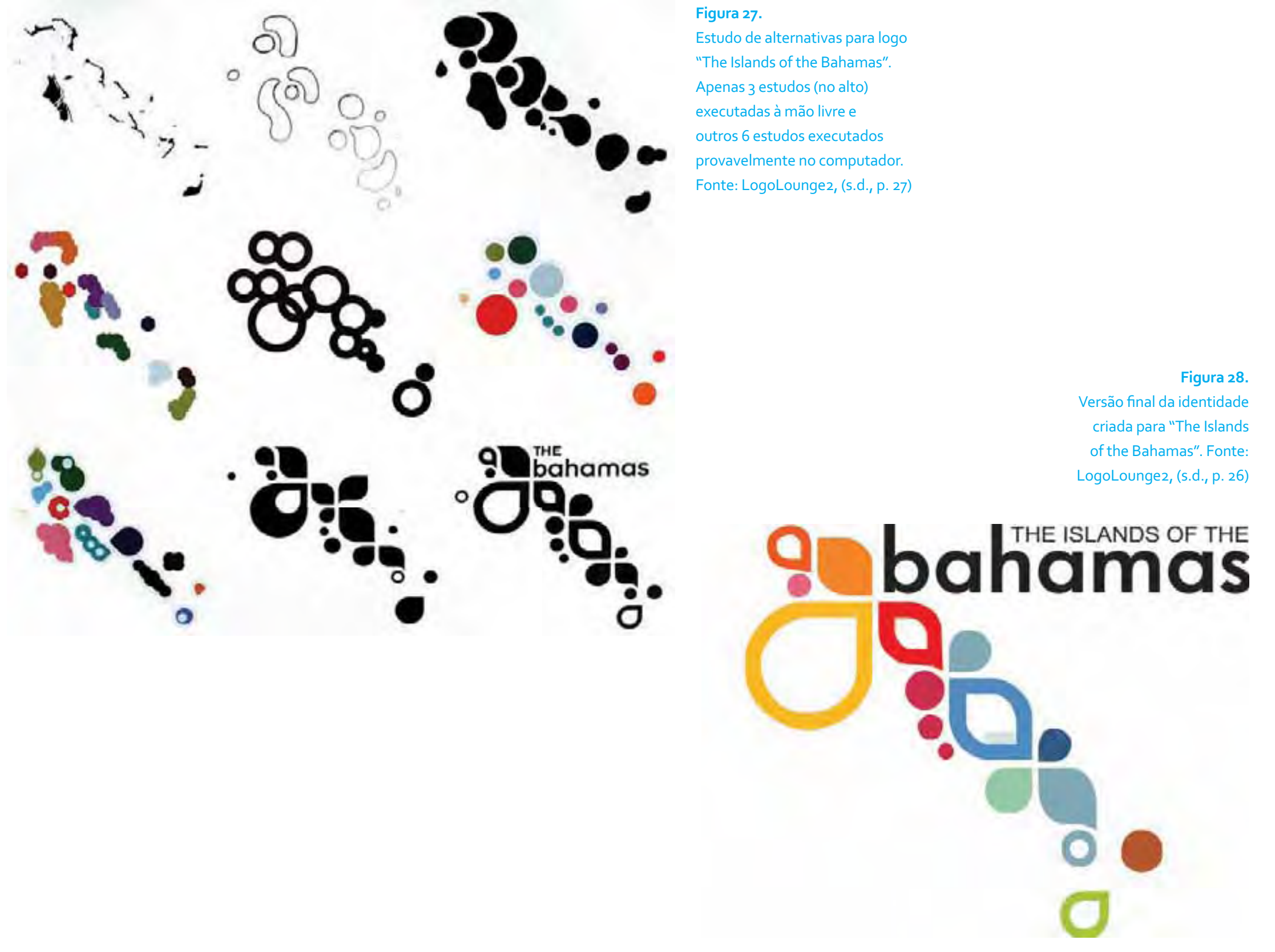
O designer Alexandre Wollner frequentemente realiza centenas de estudos à mão livre na concepção de seus trabalhos em identidade corporativa [Figuras 29 e 30].

Com a difusão dos materiais impressos no Ocidente, a partir do séc. $\mathrm{XV}$, os materiais impressos editoriais alavancaram um vasto campo da comunicação. É uma das áreas mais antigas e evidentes da comunicação visual [Figura 31]. Se desenvolveu muito desde seu surgimento a ganhou novo fôlego com a inclusão da informática no processo. Reflexo disso são a infinidade de publicações impressas, que não param de crescer, e que lotam as bancas de jornais, livrarias e sebos no mundo todo.

\section{Hendel (2003, p.11) afirma que}

"não é somente o que o autor escreve num livro que vai definir o assunto do livro. Sua forma física, assim como sua tipografia, também o definem. Cada escolha feita por um designer causa algum efeito sobre o leitor."

Do mesmo modo, os projetos gráficos de jornais e revistas devem interagir com o assunto para que este seja transmitido com a maior clareza possível

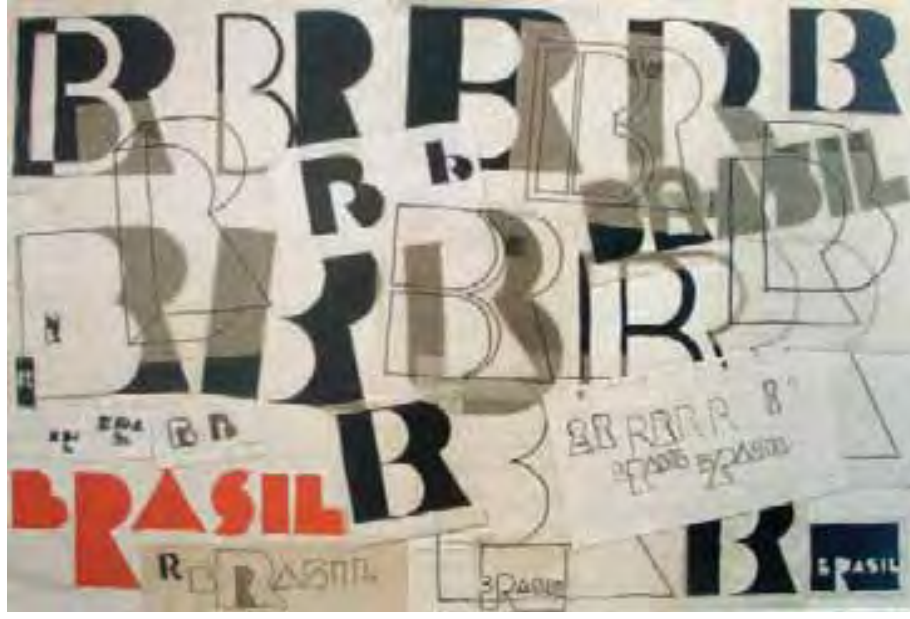

Figura 29

Estudos de

Alexandre Wollner para a identidade das Fechaduras BR. Fonte: Wollner (2003, p. 263)

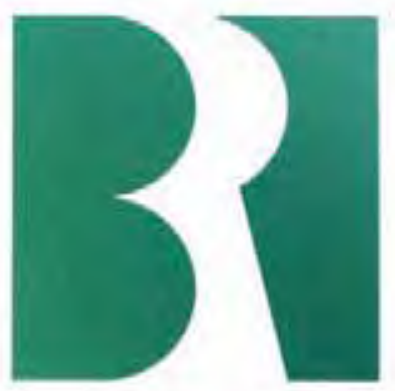

Figura 30. Arte final de

Alexandre Wollner para a identidade

das Fechaduras

BR. Fonte: Wollner

(2003, p.267) 


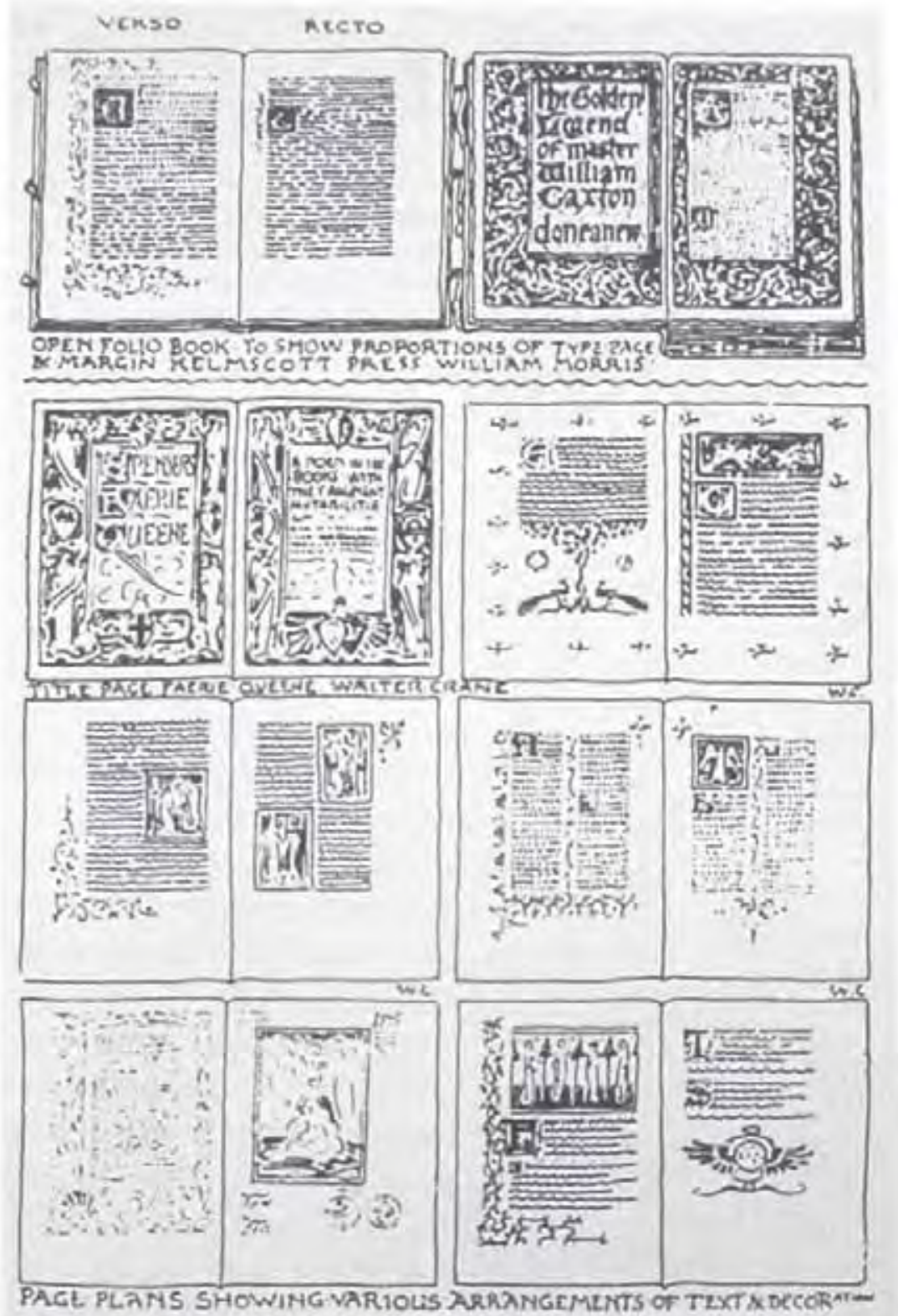

Figura 31.

Estudos de Walter

Crane para o livro

The Bases of Design

(As Bases do Design),

1898, evidenciando

o planejamento de

páginas duplas. Fonte:

Meggs (2009, p. 226) 
Dentro do projeto gráfico editorial, vários componentes têm de ser definidos para que essa comunicação seja efetiva. Cabe ao designer selecionar entre todos os componentes (a tipografia, as cores, as imagens, as legendas, o sumário, etc.), aqueles que terão maior destaque e como serão dispostos. Essas atribuições variam de acordo com o tipo de mídia (livro, revista, jornal) e até mesmo dentro dela (livro de medicina, história, ficção, para crianças, para gestantes, com ilustrações, coleções, etc.). Cada projeto é único e, portanto, pede uma linguagem e uma configuração própria.
As imagens a seguir [Figuras 32 e 33] apresentam os desenhos do designer Ron Costley para projeto gráfico de livro. Na Figura 32 pode-se ver os estudos de detalhes do livro, porém já com uma certa precisão no traçado, além de algumas anotações de unidades de medida. Na Figura 33, os desenhos já evidenciam a configuração dos elementos nas página, e também com as dimensões das entrelinhas e fontes em unidades de pontos, mostrando como várias questões já estão resolvidas e como o processo de concepção já está mais bem definido. Essa é uma fase de transição dentro dos projetos gráficos que têm sido executados no computador.

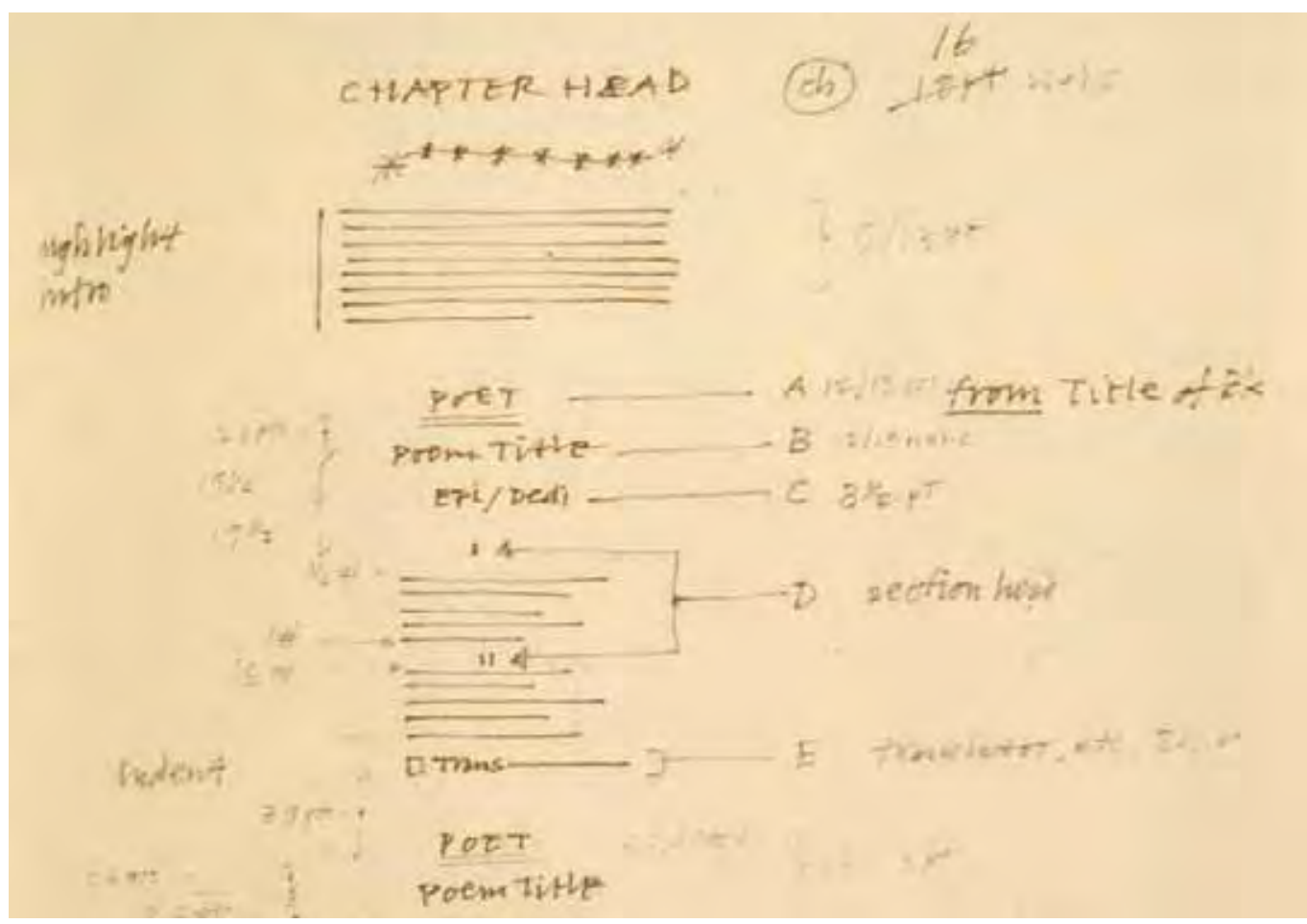

Figura 32.

Estudo de detalhes

do designer Ron

Costley para projeto

gráfico de livro.

Fonte: Hendel

(2003, p.115) 


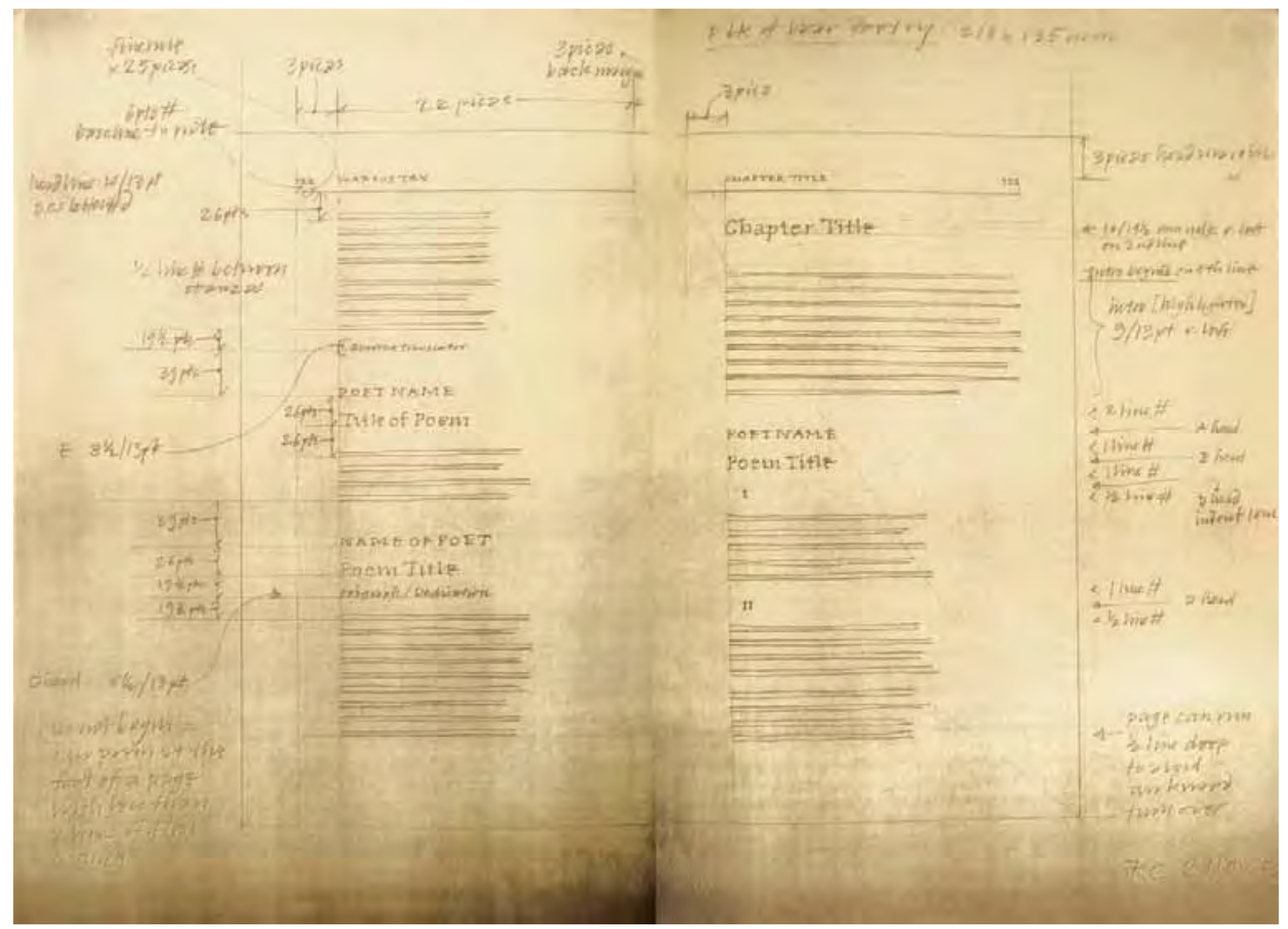

Figura 33.

Estudos de configuração

dos elementos na página

do designer Ron Costley para

projeto gráfico de livro. Fonte:

Hendel (2003, p.116-117) 
A infografia é um dos exemplos mais consistentes da evolução da comunicação visual editorial. Sua grande difusão nos últimos anos contribui para o esclarecimento do processo de comunicação visual. Sua produção demanda uma grande carga de relação entre texto e imagem, por isso o entendimento e a associação das informações que serão apresentadas é fundamental para a concepção deste tipo de trabalho. Requer bastante domínio de aspectos conceituais e entendimento do problema, conhecimento de técnicas e muito planejamento.

Segundo o diretor de infografia da Editora Abril, Luiz Iria, para todo infográfico são realizados desenhos de expressão, desenvolvido por designers mais experientes ou também por jornalistas. A partir daí são desenvolvidos desenhos mais refinados pelos próprios designers e/ou ilustradores e então começa a produção de fotos e outras ilustrações que irão compor o infográfico. As imagens abaixo [Figuras 34, 35 e 36] ilustram algumas etapas de construção do infográfico sobre o acidente do vôo AF447, produzido pela Equipe de Arte da revista Época.

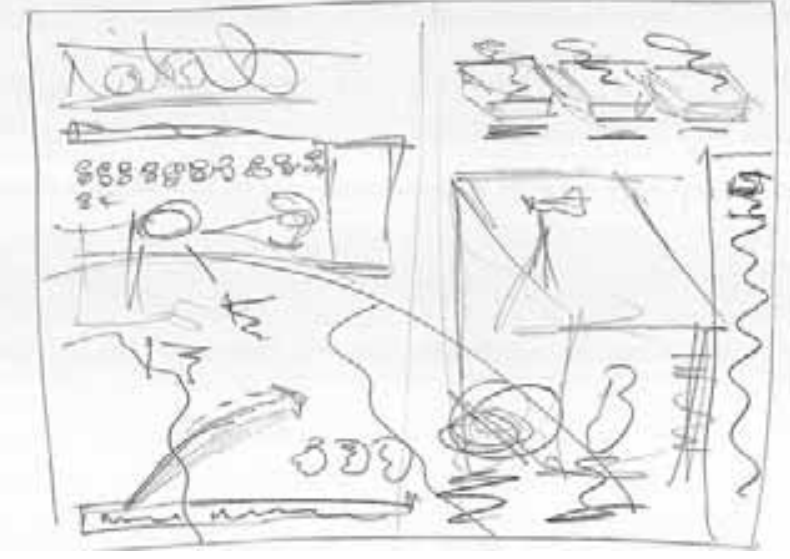

Figura 34.

Desenho inicial executado à mão

livre, para infográfico sobre acidente do

avião $\mathrm{AF}_{447}$ para revista Época,

Equipe de Arte da revista Época. Fonte: Vergotti (2009a).

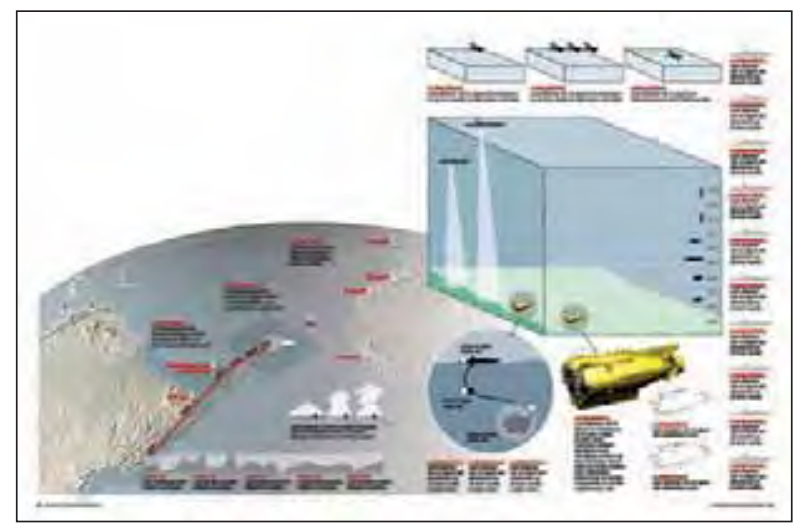

Figura 35. (abaixo) Desenho (digital) mais detalhado/ refinado da Equipe de Arte da revista Época sobre acidente do avião $A F 447$ para infográfico da revista Época. Fonte: Vergotti (200gb)

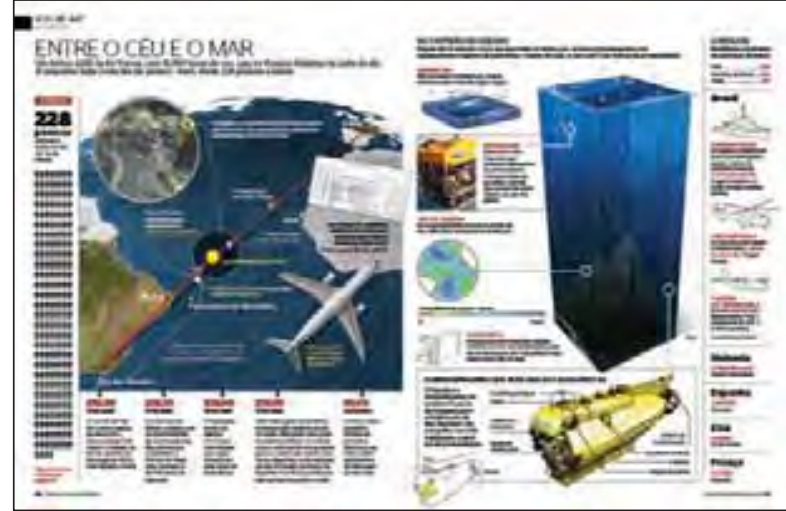

Figura 36.

Versão final do infográfico sobre acidente do avião AF447 para revista Época, Equipe de Arte da revista Época. Fonte: Vergotti (2009c) 
Apesar da versão final ter ficado um pouco diferente dos desenhos preliminares [Figura 34], no que diz respeito aos locais especificados para cada informação, fica claro como os aspectos globais já foram definidos no primeiro desenho, com a divisão entre a imagem do trajeto e local do acidente na página da esquerda e os detalhes de busca na página da direita. Outro detalhe interessante está presente na imagem da Figura 35, que foi concebida já no computador, onde é possível organizar melhor outras informações mais detalhadas considerando o grid $^{2}$ da revista. Na versão final [Figura 36] pode-se observar também que o modo como as informações foram apresentadas mudou bastante ainda em relação à imagem anterior [Figura 35]. Isso mostra como as percepções mudam no decorrer do processo, quando a visualização do todo já é mais clara e algumas informações ou ideias podem surgir no meio do processo. Porém, essas informações que aparecem no meio do processo, podem indicar também que não houve uma preocupação conceitual muito grande no início do projeto.

A grande diferença entre o primeiro e o segundo desenho [Figuras 34 e 35] pode indicar também que houve pouca exploração a partir do desenho-expressional em torno do problema a ser resolvido. O processo de investigação e busca de alternativas pode ter sido minimizado em função de vários fatores, entre eles o tempo para produção; este, por sua vez, diminui-se gradativamente com o domínio da técnica.
O desenho de comunicação aplicado à rede mundial de computadores, a internet, é um exemplo claro de como os processos tecnológicos não aboliram os recursos do desenho de expressão. Radfahrer (s.d.) apresenta a metodologia que usa para criação de sites, baseada em 4 grandes fases [Figura 37]: Lápis (conceito, planejamento e organização da estrutura); Photoshop (criação, produção e integração do conteúdo); Código (programação e testes); e Manutenção (lançamento, atualização e suporte); totalizando 11 etapas, que são feitas individualmente mas podem se acumular, se inverter ou englobar outras etapas no decorrer do processo (RADFAHRER, s.d.).

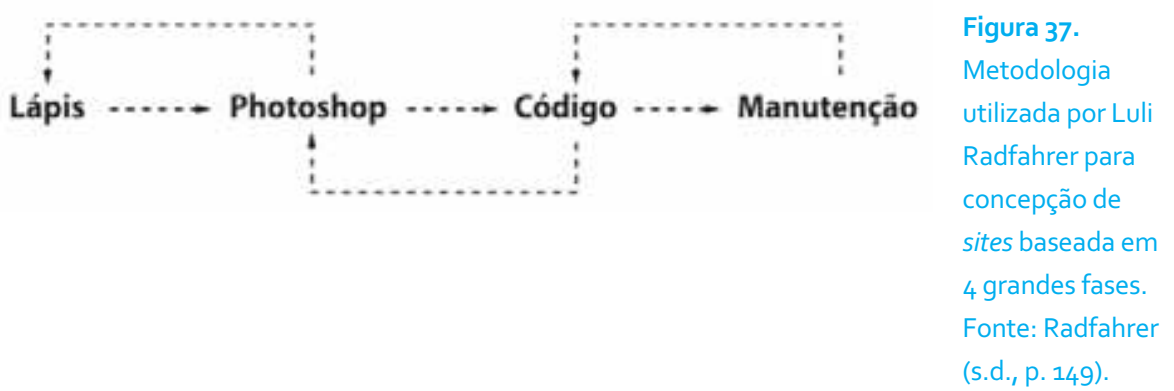

2. Grid. [ingl.] Trama ou malha modular que serve como base para a construção de diagramas. Fonte: ADG (s.d., p.54). 
Radfahrer (s.d.) ainda apresenta uma imagem do autor do prefácio do seu livro, Paulo Jorge Pereira, na época sócio-diretor de criação da Agência Click, com a seguinte descrição: "Repare que ele tem um lápis na mão, não um mouse. Isso (e não os cyberlions ${ }^{3}$ que ele conquistou) faz toda a diferença."(RADFAHRER, s.d., p.5).
Na área de produção de vídeo, onde encontram-se as animações desenvolvidas para televisão, cinema e mesmo para a internet, existem os desenhos de expressão, utilizados na concepção desses projetos, conhecidos como storyboards ${ }^{4}$ [Figura 38]. É uma invenção que surgiu com o filme Os três porquinhos, em 1933, sendo a solução proporcionada pelos artistas da Disney para os problemas de ordem e estrutura do filme de animação.

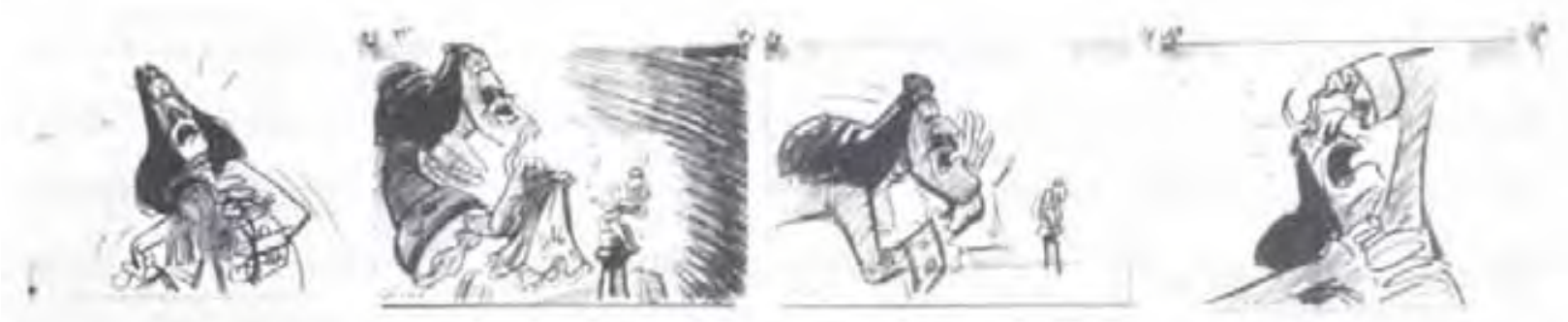

3. Cyberlions. Prêmio do Festival de Cannes destinado à categoria de sites, campanhas interativas e de publicidade online. Fonte: Wikipedia (s.d.)

4. Storyboard. "Série de pequenos desenhos com legendas, fixados num quadro, que mostram as ações-chave do filme" (BARBOSA JÚNIOR, 2002 p. 109)

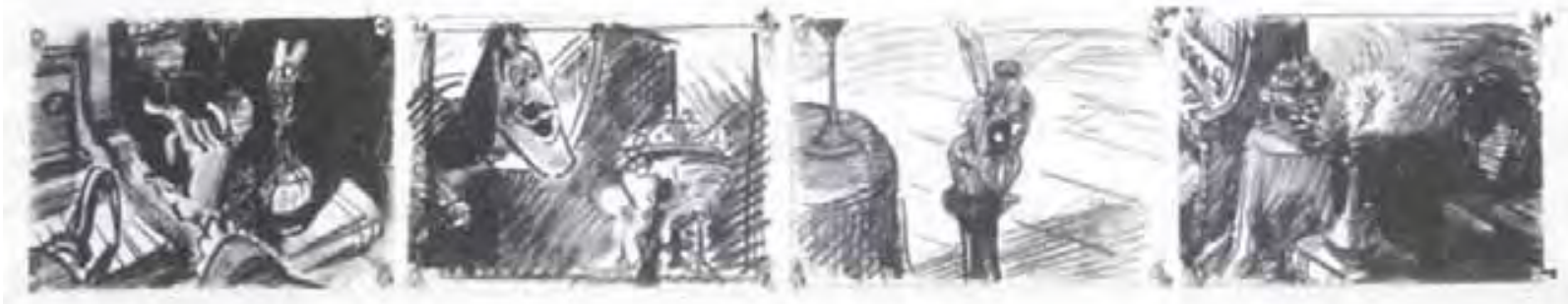

Figura 38. Storyboard (Peter Pan, 1953), onde se trabalham continuidade, ângulos
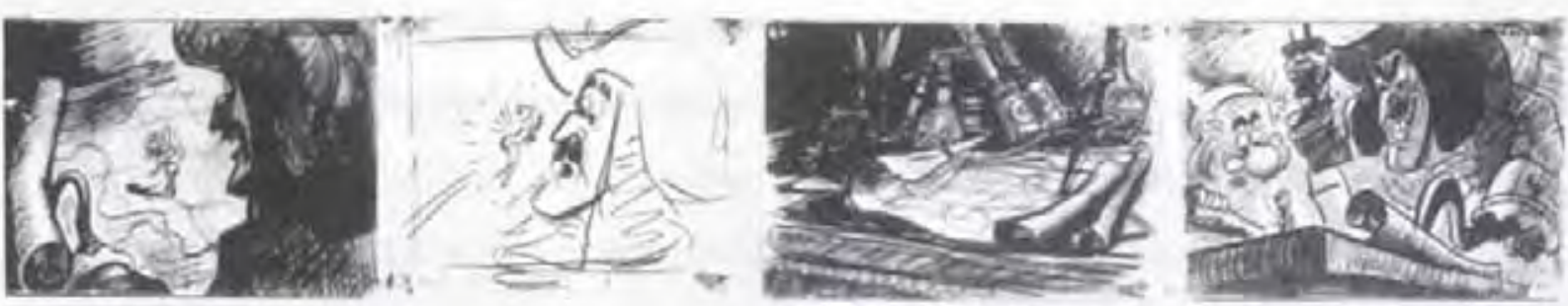

de câmera, encenação، planificação,

movimento, etc., Walt Disney Studio.

D Disney Enterprises, Inc. Fonte: BARBOSA JÚNIOR (2002, p. 111) 
A prática de se desenvolver storyboards para vídeos ainda é bastante comum nos dias atuais. Em muitos casos envolvem também o uso de cores. O exemplo da Figura 39 reforça o auxílio do desenho expressional na definição do problema (neste caso o roteiro) e a organizar o projeto, ampliando a visão do todo.

No desenvolvimento do personagem criado pela agência Macacolândia para Hershey's foram desenvolvidos muitos desenhos. A Figura 40 apresenta apenas uma parte desses desenhos. Apesar da importância desse tipo de desenho no processo, a grande quantidade de transformações de enfoque pode indicar que o processo investigativo foi bastante valorizado mas também que o criador possui um domínio e um repertorio bastante vasto, porém pode indicar também que as questões de definição do problema e os conceitos que deveriam ser abordados não foram suficientemente resolvidos antes do início dos desenhos.

Em resumo percebe-se que em projetos de comunicação visual o uso de desenhos de expressão sempre esteve presente, mesmo em projetos executados há centenas de anos atrás e sua necessidade de utilização está bastante atrelada ao fator produtivo e principalmente ao nível de investigação com que cada projeto é desenvolvido. É evidente a imprecisão de linguagem na definição dos termos que contemplam o desenho expressional, tornando urgente sua classificação e definição. Os estudos e pesquisas sobre o desenho expressional e sua própria importância ganharam força com a inclusão da informática no processo de projeto e mostram que existe ainda um vasto campo muito importante no processo criativo que merece ser explorado.

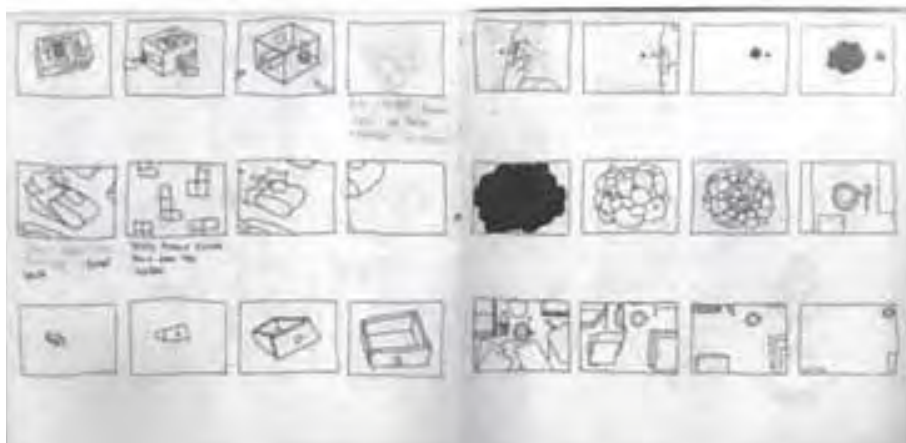

Figura 39.

Storyboard de Johnny Kelly: "mudar de quatro para doze painéis por página fez com que eu parasse de desenhar frames muito elaborados e me ajudou a focar na sequência de eventos e no roteiro" (COMPUTER ARTS, 2009, p.49).

Figura 40.

Estudos de personagem evidenciando mudanças de enfoque bastante refinadas, provavelmente devido à fluência gráfica do criador. $O$ desenho a cores contempla a versão final. Fonte: MACACOLÂNDIA (s.d.).

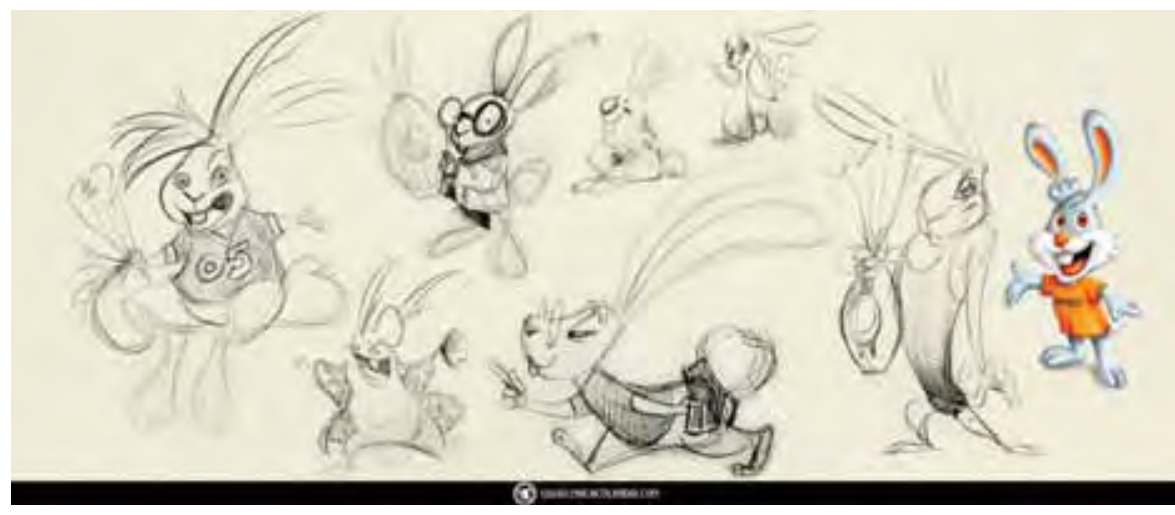




\section{Capítulo 3}

\section{Pesquisa de campo}

Procedimentos da pesquisa 59

Tipo de pesquisa 60

Métodos 60

Coleta de dados 60

Sujeitos 62

Perfil dos entrevistados $\mathbf{6 2}$

Instrumento para coleta de dados 64

Resultados 68 


\section{Procedimentos da pesquisa}

A pesquisa foi organizada em duas fases. Na primeira foi feito um levantamento bibliográfico como forma de enriquecer o repertório, esclarecendo alguns pontos da pesquisa, além de servir como base para a construção do formulário empregado na pesquisa de campo, que constituiu a segunda fase dessa pesquisa. A fase de levantamento bibliográfico foi considerada de primeiro plano em virtude das próprias descobertas realizadas. Já a fase da pesquisa de campo ficou em segundo plano, servindo apenas para avaliar algumas hipóteses.

Um dos pontos que merecem ser esclarecidos aqui é o redirecionamento que a presente pesquisa tomou em função do levantamento bibliográfico. Esta pesquisa tinha como objetivo inicial analisar a importância do esboço diante das novas tecnologias (computador). Porém, a partir do levantamento bibliográfico constatou-se que essas questões já tinham sido pesquisadas e foram consideradas suficientes, não necessitando de uma nova pesquisa com esse direcionamento. Alguns dados colhidos destas pesquisas foram apresentados na fundamentação teórica. Além disso, as questões de terminologias também foram entendidas como importantes e determinantes para a construção concisa do presente trabalho. A partir de então a pesquisa tomou outro rumo e a questão do desenho de expressão e seu envolvimento no processo criativo se tornou mais relevante nesse momento. 


\section{Tipo de pesquisa}

Do ponto de vista dos objetivos, a pesquisa bibliográfica foi exploratória, como forma de proporcionar maiores informações sobre o assunto investigado, facilitando a delimitação do tema da pesquisa, orientando a fixação dos objetivos e a formulação das hipóteses, permitindo descobrir um novo tipo de enfoque para o assunto (ANDRADE, 2004). Já para a pesquisa de campo foi adotada a pesquisa descritiva, observando os fatos, registrandoos, analisando-os, classificando-os e interpretando-os, sem a interferência do pesquisador sobre eles (ANDRADE, 2004).

\section{Métodos}

O método de abordagem escolhido para a pesquisa de campo foi indutivo, como forma de estabelecer uma conexão ascendente (ANDRADE, 2004), partindo de opiniões particulares como forma de generalizar essas mesmas opiniões.

\section{Coleta de dados}

A coleta de dados foi realizada através de entrevista padronizada ou estruturada, utilizando-se um formulário aplicado a todos os informantes, para se obter respostas para as mesmas perguntas (ANDRADE, 2004). A coleta foi realizada em salas de aula, pelos próprios professores das disciplinas projetuais. A decisão pela coleta de dados a partir dos professores foi tomada como forma de se interferir o menos possível com os sujeitos da pesquisa. 
O método de abordagem com os professores se deu primeiro a partir de contato telefônico e depois por contato pessoal. Nesta ocasião foram esclarecidos alguns pontos do assunto tratado na pesquisa e como deveria ser aplicada, além de serem entregues os envelopes contendo a ficha de pesquisa. Na parte externa do envelope foram anotados os dados referentes à disciplina pesquisada, além da seguinte descrição: "Questionário referente ao principal projeto desenvolvido na disciplina", já que em alguns casos, constatou-se que havia mais de um projeto desenvolvido pelos alunos na disciplina. Assim optou-se, nesses casos, em aplicar a pesquisa somente naquele projeto que tivesse maior importância, equalizando com outras disciplinas que normalmente desenvolviam um projeto mais elaborado como trabalho final da disciplina

Como a pesquisa trata dos processos desenvolvidos durante o projeto, ela foi aplicada ao final do semestre letivo, ocasião em que os alunos já tinham passado pelo processo criativo, que é a parte que interessa efetivamente à pesquisa. Esse foi outro motivo pelo qual os questionários foram aplicados pelos próprios professores, como forma de padronizar a aplicação da pesquisa em "fases equivalentes" do projeto entre turmas diferentes. Os formulários foram aplicados nos meses de junho (turmas de projeto 5) e novembro (turmas de projeto 6) de 2009. 


\section{Sujeitos}

O formulário foi aplicado aos alunos do Cursos de Desenho Industrial (Projeto do Produto e Programação Visual) da Faculdade de Arquitetura, Artes e Comunicação da Universidade Estadual Paulista "Júlio de Mesquita Filho", em Bauru, São Paulo, nas disciplinas de Projeto 5 - turmas em PV-Diurno e Noturno e PP $-5^{\circ}$ termo, nas disciplinas de Projeto 6 - turmas em PVDiurno e Noturno e PP $-6^{\circ}$ termo, totalizando a amostra em 122 alunos [Tabela 1].

\begin{tabular}{|lr}
\hline Entrevistados \\
\hline Total de alunos de Programação Visual & $\mathbf{9 0}$ \\
Total de alunos de Projeto do Produto & $\mathbf{3 2}$ \\
\hline Total geral de alunos entrevistados & $\mathbf{1 2 2}$ \\
\hline
\end{tabular}

\section{Perfil dos entrevistados}

\section{- Projeto 5 - Programação Visual-Diurno}

Total de alunos entrevistados: 22 alunos, sendo 12 homens e 10 mulheres entre 19 e 24 anos.

Descrição do projeto pesquisado: material promocional impresso e/ou eletrônico para auto divulgação do aluno como designer em sua especialidade.

Projeto individual.

Programa da disciplina (Anexo A) 


\section{- Projeto 5 - Programação Visual-Noturno}

Total de alunos entrevistados: 23 alunos, sendo 15 homens e 8 mulheres entre 20 e 36 anos.

Descrição do projeto pesquisado: material promocional impresso e/ou eletrônico para auto divulgação do aluno como designer em sua especialidade.

Projeto individual.

Programa da disciplina (Anexo A)

- Projeto 5 - Projeto do Produto

Total de alunos entrevistados: 12 alunos, sendo 6 homens e 6 mulheres entre 21 e 29 anos.

Descrição do projeto pesquisado: meio de transporte individual movido pelos pés.

Projeto em grupos de 2, 3 ou 4 membros.

Programa da disciplina (Anexo B)

\section{- Projeto 6 - Programação Visual-Diurno}

Total de alunos entrevistados: 15 alunos, sendo 9 homens e 6 mulheres entre 19 e 23 anos.

Descrição do projeto pesquisado: projeto gráfico de revista.

Projeto individual.

Programa da disciplina (Anexo C)

\section{- Projeto 6 - Programação Visual-Noturno}

Total de alunos entrevistados: 30 alunos, sendo 15 homens e 15 mulheres entre 20 e 36 anos.

Descrição do projeto pesquisado: projeto gráfico de revista. Projeto individual.

Programa da disciplina (Anexo C)

\section{- Projeto 6 - Projeto do Produto}

Total de alunos entrevistados: 20 alunos, sendo 13 homens e 7 mulheres entre 17 e 30 anos.

Descrição do projeto pesquisado: kit de jardinagem amador. Projeto em grupo de 2, 3, 4, 5 ou 6 membros.

Programa da disciplina (Anexo D) 


\section{Instrumento para coleta de dados}

Foi utilizado um formulário contendo 16 questões como instrumento para coleta de dados. As questões do formulário foram criadas de modo a se investigar aspectos que indicassem a utilização ou não do desenho-expressional. A formulação das questões passou por várias etapas e não foi construída de uma vez só. Ela foi construída e reformulada com base nas hipóteses surgidas com os levantamentos bibliográficos. Durante o processo de desenvolvimento do formulário foram realizados vários estudos de quais questões seriam colocadas e como seriam distribuídas, além de sua diagramação e disposição.

Uma preocupação que percorreu todo esse processo foi a de tornar o questionário o mais fácil de ser entendido e interpretado pelos alunos. Para isso foram realizados cerca de 20 estudos e testes até a definição do modelo final [Figura 41]. O modelo em tamanho real está disponível no Apêndice A.

O termo esboço/croqui foi utilizado como forma de deixar o mais claro possível o objeto de estudo do formulário. Já que a definição por um termo adequado foi bastante trabalhosa, o uso de um termo novo ou muito específico poderia dificultar seu entendimento ou necessitar de algum esclarecimento. Assim utilizou-se os termos mais genéricos, esboço e croqui, representando o desenho/expressional. 


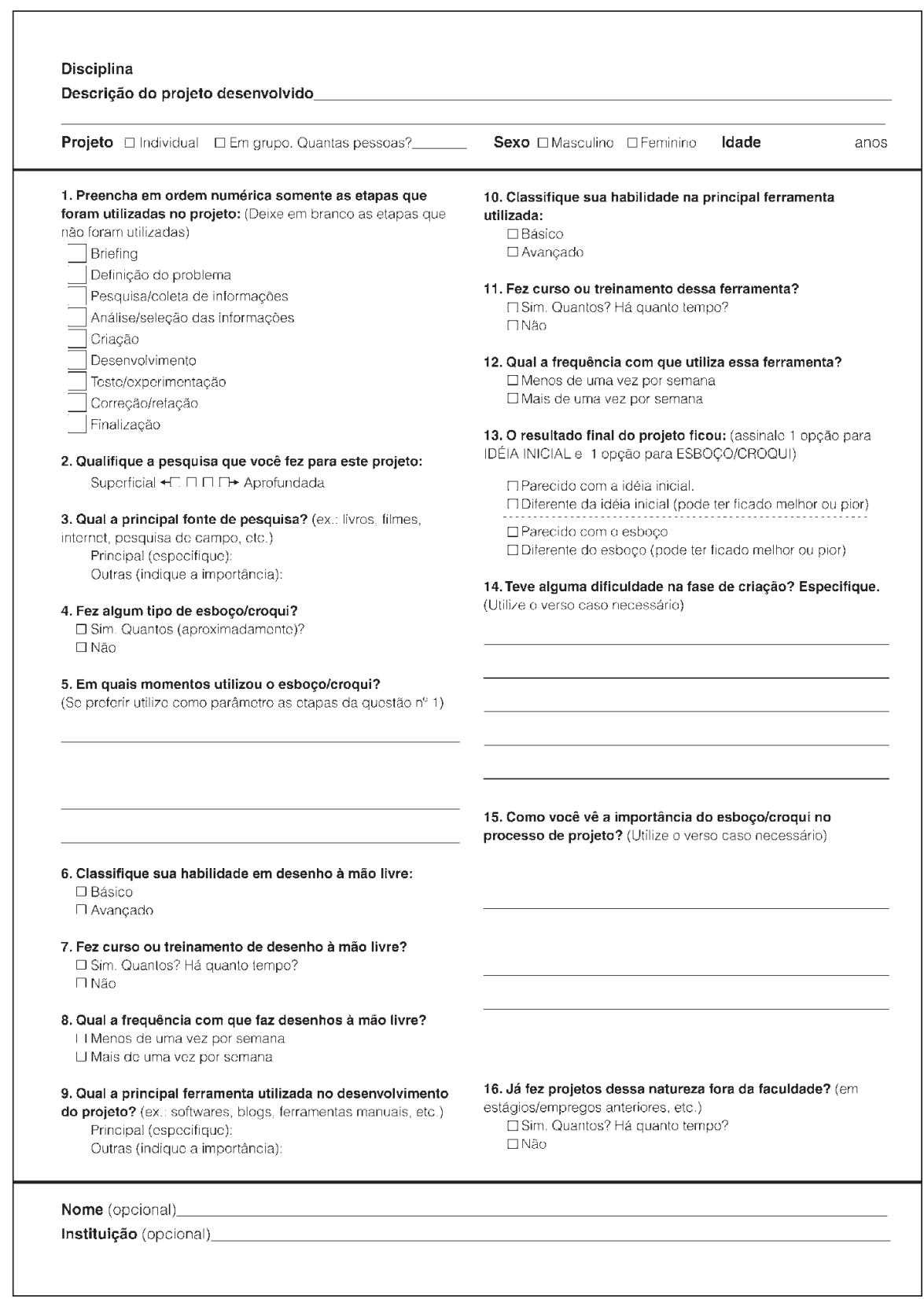


Abaixo segue descrição de função de cada item do formulário de pesquisa:

Como a pesquisa seria aplicada em disciplinas diferentes, com projetos diferentes, havia a necessidade de saber qual a disciplina e uma breve descrição do projeto desenvolvido. O grau de inovação de cada projeto é uma questão interessante, que talvez pudesse responder algumas hipóteses em relação ao uso do desenho expressional. Porém é uma questão muito pessoal e um mesmo projeto poderia ser mais inovador para um aluno que não tem um repertório muito vasto naquele tipo de projeto do que para o aluno que já possui mais experiência e repertório para o mesmo projeto. Assim, essa questão do grau de inovação do projeto ficou em segundo plano.

Quanto ao tipo de projeto (individual ou em grupo): Parte-se da hipótese de que um trabalho em grupo aumente o repertório, facilitando a visualização do projeto, exigindo menor uso do desenho expressional. Os campos sexo e idade foram colocados somente como forma de registro para uma eventual comparação do uso deste tipo de desenho, porém não é o foco desta pesquisa.
Questão 1 (metodologia): A indicação do uso ou não de etapas da metodologia, e de quais etapas pode trazer algum esclarecimento com relação à aplicação de metodologias, aplicação de metodologias lineares, utilização do processo como um todo. Esse modelo de metodologia foi adaptado de Munari (1981) e Lobach (2001), e também com base em algumas pesquisas e a própria experiência como designer gráfico. O uso da etapa pesquisa é um ponto importante para a presente pesquisa que parte da hipótese de que a pesquisa aumenta o repertório estimulando as ideias, motivando a necessidade do registro, e assim do desenho expressional. Outras informações desta questão também podem servir para futuras relações.

Questões 2 e 3 (pesquisa): Identificar o grau de pesquisa realizada, bem como a fonte de pesquisa para indicar a qualidade das informações levantadas.

Questões 4 e 5 (esboço/croqui): Questão principal desta pesquisa - a utilização ou não do desenho expressional e sua intensidade (quantidade). Parte-se da hipótese que esta resposta esteja vinculada praticamente a todas as repostas das outras questões. A questão 5 responde se a utilização do desenho expressional está vinculada a alguma fase específica. Parte-se da hipótese que é muito utilizado na fase de criação, porém acredita-se que este tipo de desenho não é uma etapa, mas sim um recurso e pode ser útil em várias etapas do projeto. 
Questões 6, 7 e 8 (habilidade no desenho à mão livre): Responde o grau de habilidade no desenho à mão livre e se o uso do desenho expressional está vinculado à habilidade ou não do desenho à mão livre.

Questão 9 (ferramenta utilizada no desenvolvimento do projeto): indica a principal ferramenta utilizada no processo. Partese da hipótese que o computador seja a principal, ferramenta utilizada.

Questões 10, 11 e 12 (medir a habilidade na principal ferramenta indicada na questão 9): Responde o grau de habilidade na ferramenta utilizada e se o uso do desenho/expressional está vinculado à habilidade ou não dessa ferramenta.

Questão 13: indicar uma possível relação da utilização do desenho-expressional entre a idéia inicial e o resultado final do projeto. É uma questão de segundo plano.

Questão 14: Parte-se da hipótese que o uso do desenho expressional diminua as dificuldades do projeto. É uma questão genérica e a dificuldade pode não estar ligada diretamente a este tipo de desenho, por isso foi colocada a questão aberta.
Questão 15: Essa questão é importante para saber como os alunos estão enxergando o recurso do desenho expressional. As respostas dessa questão poderão contestar as informações obtidas na questão 4. A questão foi colocada em aberto para não limitar as respostas, dando liberdade a eventuais surpresas ou considerações ainda não levantadas na pesquisa bibliográfica a respeito do desenho-expressional.

Questão 16: Responde o grau de experiência que o aluno tem no projeto desenvolvido, partindo da hipótese que o aluno que já tenha mais experiência visualize com mais facilidade suas ideias e não tenha tanta necessidade de uso do desenho expressional.

Por último estão os campos nome do aluno e instituição a que pertence. Estas informações foram colocadas no final pois são de menor importância. São optativas para dar liberdade ao aluno responder com sinceridade sem ser identificado. 


\section{Resultados}

Os resultados apresentados a seguir são:

- quantidade e fases de uso do desenho/expressional

- dificuldade na criação, com filtros relacionando com o uso do desenho expressional, com a habilidade no desenho à mão livre, com a habilidade na principal ferramenta utilizada, e com o nível de experiência no projeto desenvolvido;

- uso da metodologia e nível e fonte de pesquisa. 
Os dados do Gráfico 1 mostram que o desenho expressional é um recurso utilizado pela grande maioria dos alunos, representando um total de $92 \%$. Esse dado contradiz a hipótese de que os alunos não estão utilizando esse tipo de recurso. Ao separar esses dados entre as turmas [Gráfico 2], percebeu-se que os alunos de Programação Visual utilizam menos o desenho de expressão.

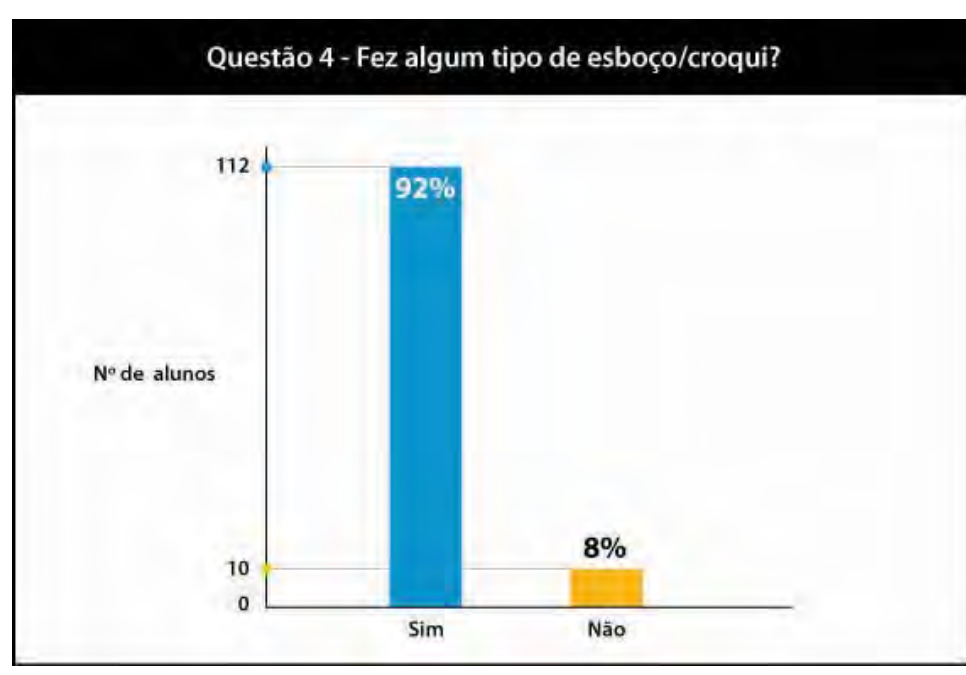

Gráfico 1.

Utilização

do desenho

expressional

por número

de alunos.

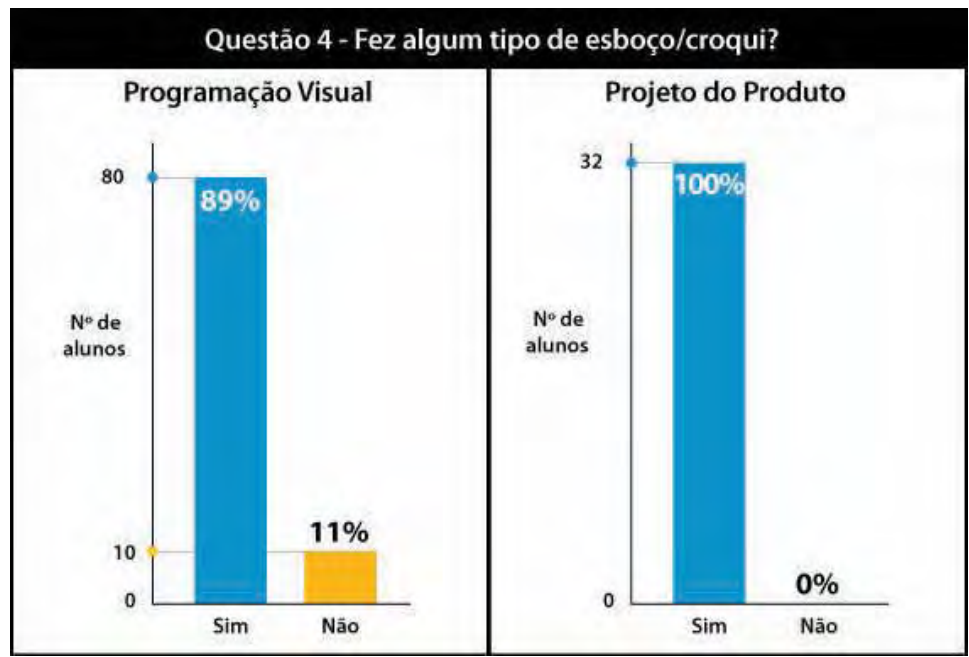

Gráfico 2.

Uso do

desenho de

expressão

separado por

habilidade. 
Apesar da grande quantidade de alunos que utilizam o desenho expressional, no Gráfico 3 percebe-se que a quantidade de desenhos desenvolvidos por cada aluno é muito pequena, sendo que quase a metade, $48 \%$ fizeram até 5 esboços. Lembrando que, de acordo com os levantamentos bibliográficos realizados, centenas de desenhos são realizados por profissionais mais experientes, contudo, a pesquisa foi realizada com estudantes universitários, que ainda não possuem experiência.

Comparando a quantidade de desenhos desenvolvidos por aluno nas duas habilidades percebeu-se uma diferença contrastante entre elas [Gráfico 4]. Considerando que os projetos desenvolvidos são de naturezas diferentes, a comparação entre as habilidades pode não ser correta. Independente desse fator, o número de desenhos realizados pelos alunos de programação visual é muito pequeno. Lembrando que o fator quantidade não é sinônimo de qualidade, no processo de aprendizado esse mesmo fator (quantidade) contribui para a qualidade. Esse é um resultado que condiz com aquilo que se esperava, em que o recurso do desenho expressional não é muito explorado. Nesse aspecto, outras pesquisas podem ser realizadas com mais profundidade, para se observar o nível de transformações realizadas através dos desenhos.
Quantidade de desenhos desenvolvidos por aluno

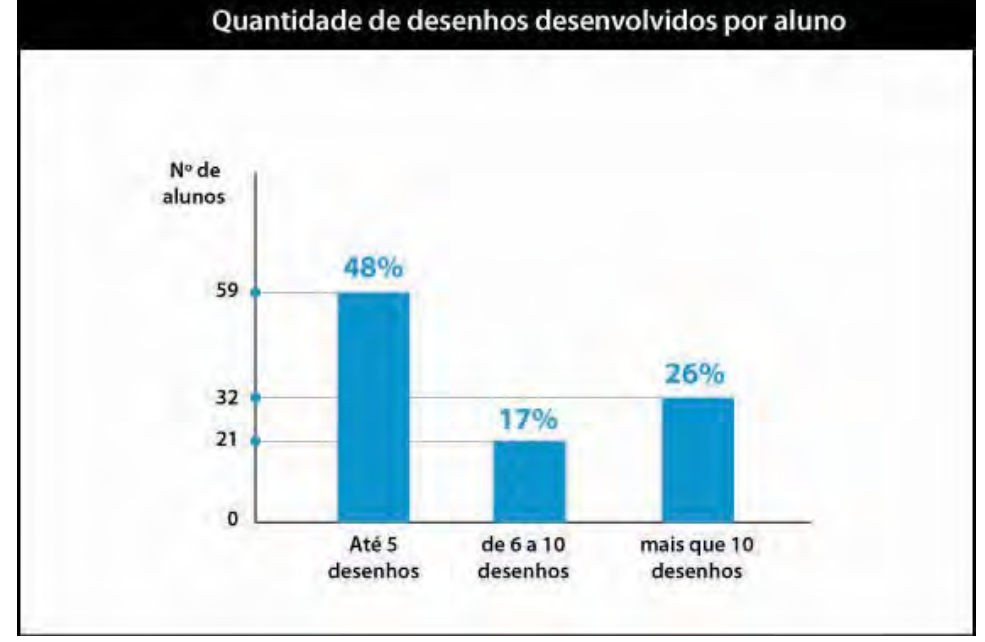

Gráfico 3.

Quantidade de desenhos

realizados

por aluno.

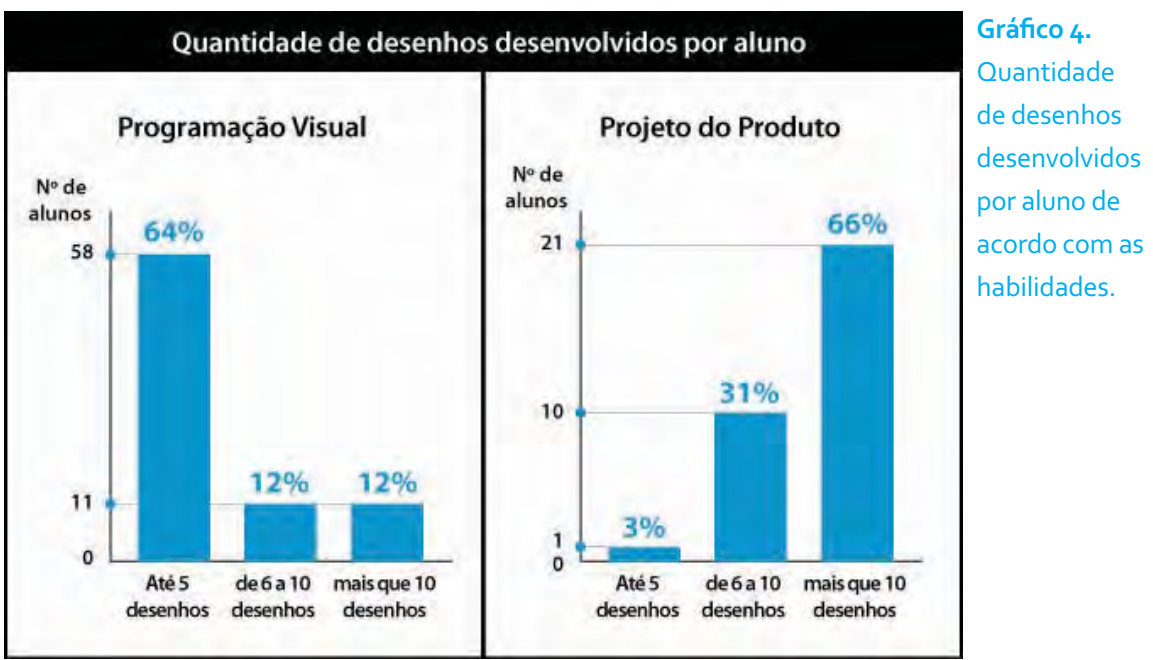


A baixa quantidade de desenhos realizados em Programação Visual pode indicar também que os projetos desenvolvidos não tenham um nível muito alto de originalidade, pois este é relativo ao repertório e experiência de cada aluno também. Através da Tabela 2 pode-se constatar a divergência entre as médias de desenhos realizados por aluno nas diferentes habilidades.

Ao comparar os alunos que tiveram dificuldades na fase de criação com os alunos que se utilizaram ou não do desenho expressional [Gráfico 5], pôde-se constatar uma grande diferença entre eles, sendo que: $49 \%$ dos alunos que fizeram desenhos apresentaram alguma dificuldade (menos da metade), enquanto que $70 \%$ dos alunos que não fizeram desenho-expressional tiveram alguma dificuldade. Assim, verifica-se que mesmo no caso de quem fez desenho expressional, a porcentagem de alunos que tiveram dificuldade ainda foi menor. A partir desses dados pode-se afirmar que existe sim uma relação entre o uso do desenho e as dificuldades enfrentadas na criação e, portanto, o uso do desenho-expressional facilita a processo criativo, mesmo não sendo muito explorado neste caso (devido à baixa quantidade de desenhos realizados por aluno).

\begin{tabular}{|lcc}
\hline \multicolumn{3}{|l}{ Quantidade de desenhos de expressão realizados } \\
\hline & & \\
\hline Desenhos realizadia por aluno em Programaçăo Visual & 357 & $\mathbf{3 , 9 7}$ \\
Desenhos realizados em Projeto do Produto & 546 & 17,06 \\
\hline Total de desenhos realizados & 903 & $\mathbf{7 , 4}$ \\
\hline
\end{tabular}

Tabela 2.

Quantidade

de desenhos

de expressão

realizados

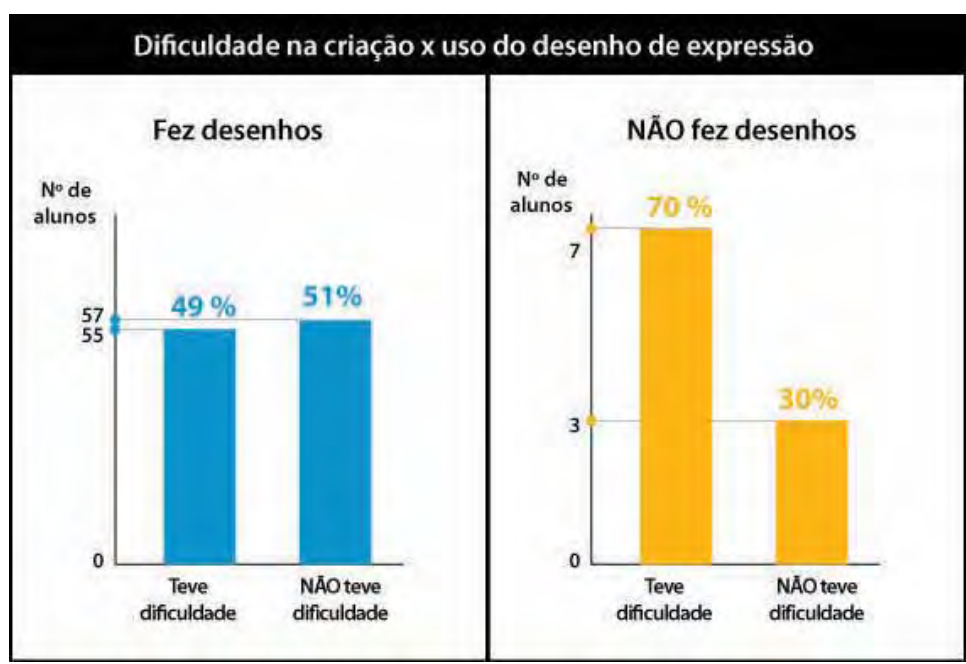

Gráfico 5

Dificuldade na

criação com

relação ao uso

do desenho de

expressão. 
Mesmo que a dificuldade esteja atrelada a aspectos mais abrangentes do que somente o desenho expressional, a comparação entre o uso do desenho e a dificuldade na criação é válida, num primeiro momento, para se ter uma ideia geral. Como pode-se observar parece haver uma grande relação entre esses dados e, portanto, uma investigação mais aprofundada pode ser bastante produtiva. A dificuldade na criação ainda foi relacionada com a habilidade à mão livre [Gráfico 6], habilidade na principal ferramenta [Gráfico 7] e experiência no projeto [Gráfico 8].

Um dado bastante interessante apresentado no gráfico 6 mostra que a maioria dos alunos possui habilidade básica em desenho à mão livre, mesmo sendo aprovados na prova eliminatória de habilidade em desenho para ingresso na faculdade, o que exige um certo grau de hablidade; enquanto que na relação entre a habilidade da principal ferramenta utilizada [Gráfico 7], grande parte dos alunos $(65,5 \%)$ afirma que possui habilidade avançada, sendo que 102 alunos (83,61\%) utilizaram o computador como principal ferramenta no desenvolvimento do projeto.

Dentre todas as relações com a dificuldade, a relação feita com o uso do desenho expressional foi a que obteve maior diferença, tornando-se até o momento o fator de maior expressividade no apoio ao processo criativo.
Dificuldade na criaçăo $x$ habilidade no desenho à mão livre

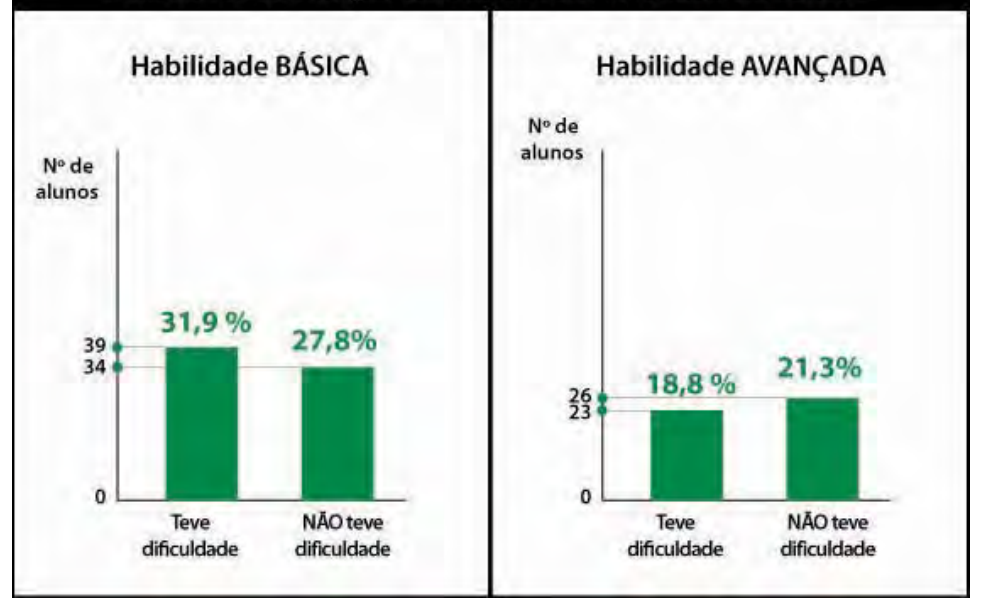

Dificuldade na criação $\mathrm{x}$ habilidade na principal ferramenta

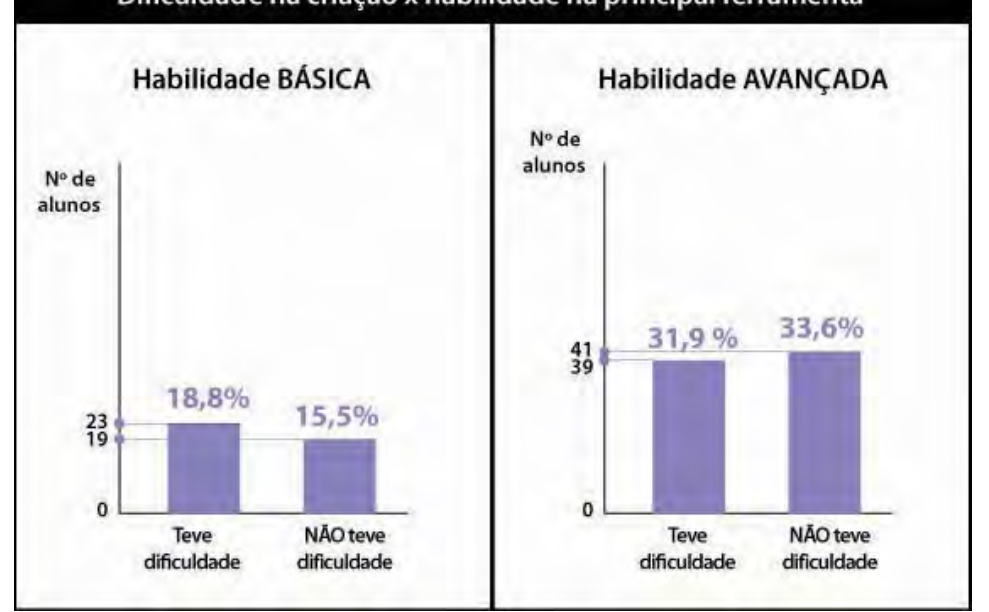

Gráfico 6.

Dificuldade na

criação em relação

à habilidade

no desenho à

mão livre.

Gráfico 7. Dificuldade na criação em relação à habilidade na principal ferramenta utilizada. 
A partir do [Gráfico 9] pode-se perceber que a utilização do desenho expressional é realizada principalmente nas fases de criação e desenvolvimento como já era de se esperar. Se considerar que o processo criativo é cíclico, como observado no levantamento bibliográfico, o ato criativo pode percorrer todo o processo de projeto e, portanto, o desenho expressional pode ser utilizado também em outras fases, principalmente nas iniciais. Na fase de pesquisa, onde podem surgir muitas idéias, a porcentagem de uso é a menor entre todas as fases, com apenas 6,2\% dos alunos utilizando o desenho nessa fase. Devido o baixo nível de utilização do desenho expressional nessas primeiras fases, pode-se afirmar que este tipo de desenho não é explorado em outras fases do projeto, principalmente como ferramenta de definição de problema, para resolver questões de importância e hierarquia dentro do projeto.

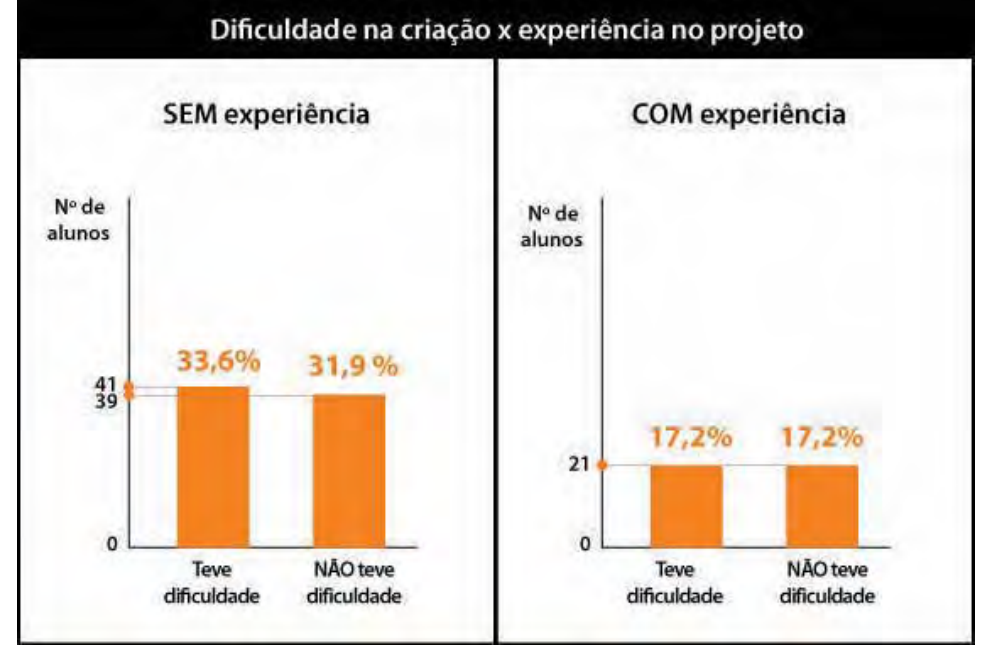

Gráfico 8 Dificuldade na

criação em relação

à experiência

no projeto

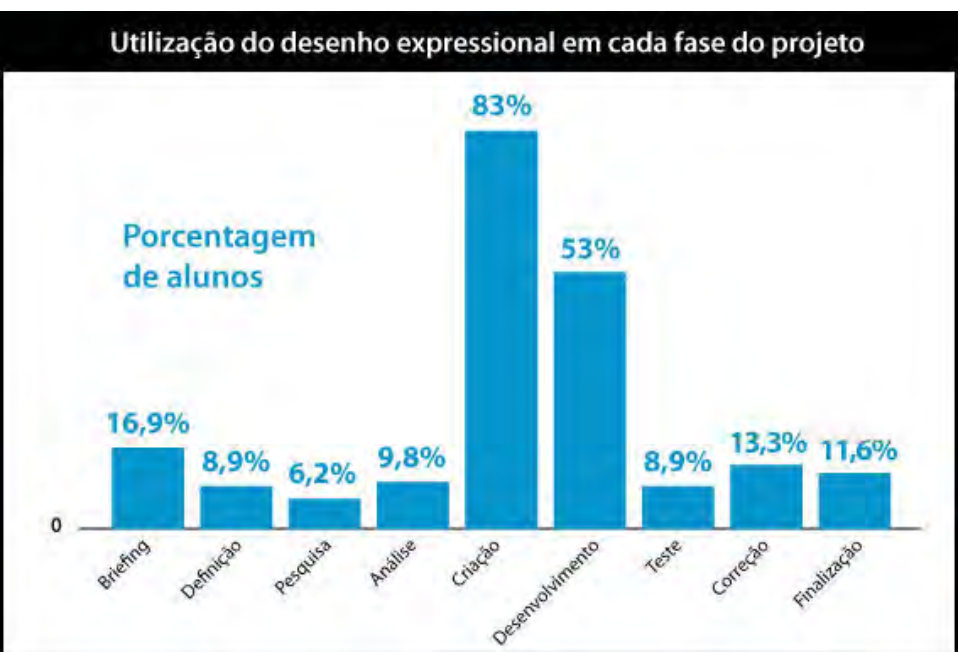

Gráfico 9 . Utilização do desenho expressional em cada fase do projeto. 
Com relação ao uso da metodologia [Gráfico 10] percebeu-se que existem algumas diferenças significativas entre os dois cursos. Na turma de Projeto do Produto o apoio ao processo é maior nas fases iniciais (briefing, definição do problema, pesquisa, análise), enquanto que nas fases de criação e desenvolvimento e finalização o índice é bastante equivalente em ambos os cursos. Já o uso das fases de teste e correção é muito mais utilizado pelos alunos de Programação Visual, provavelmente devido à diferença na facilidade de se produzir o modelo real. Mesmo assim, o uso do teste pelos alunos de PV corresponde a pouco mais da metade $-57,7 \%$, índice muito pequeno para o grau de percepção e avaliação que esta etapa pode proporcionar; na somatória dos dois cursos esse índice ficou abaixo dos 50\% [Gráfico 11],.
Utilizaçăo da Metodologia - Programaçảo Visual e Projeto do Produto

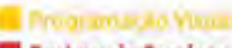

Erojeto do Produto

âde
alunos

$100 \%$
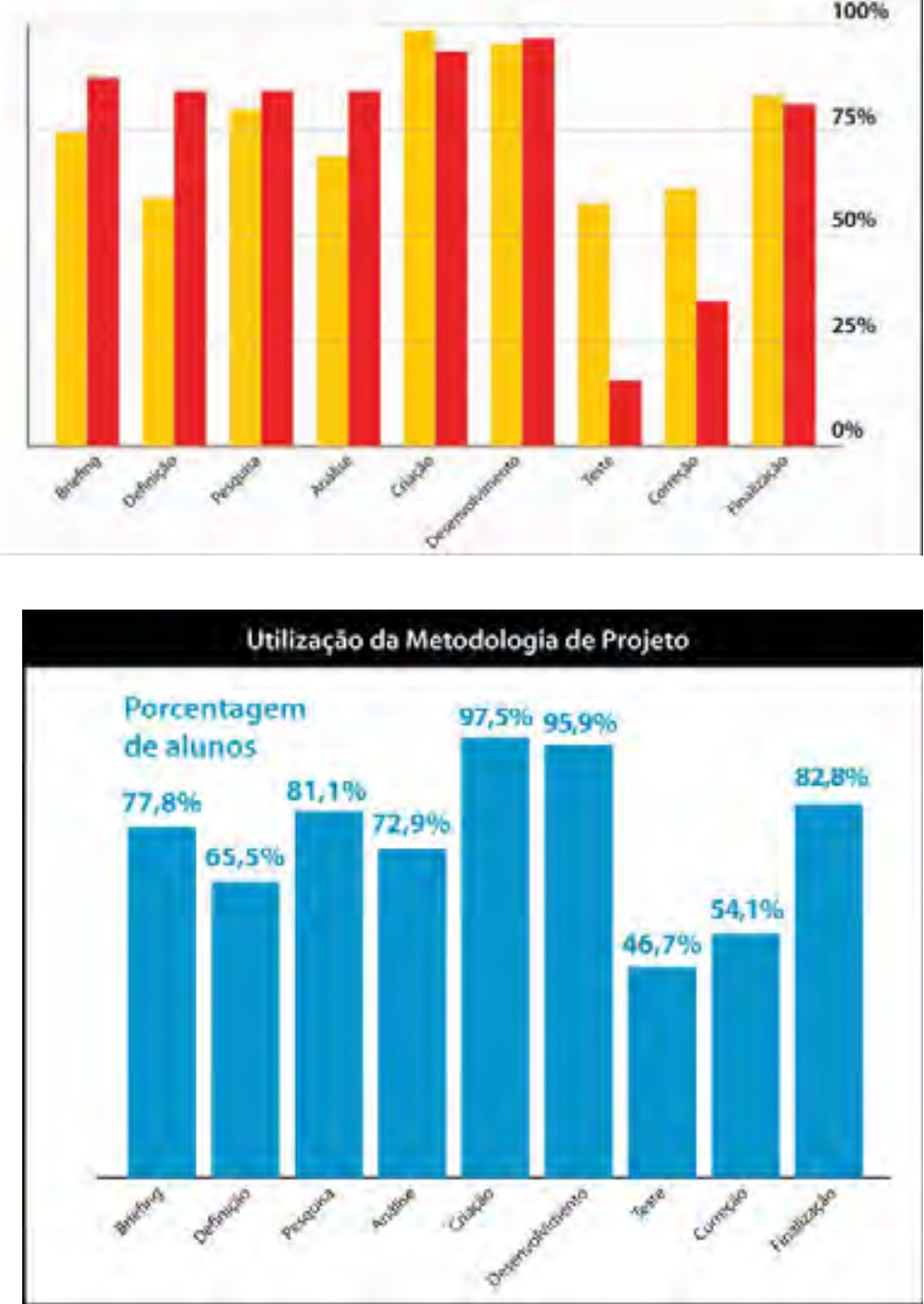

Gráfico 10.

Utilização da metodologia entre as duas habilidades.
Gráfico 11. Utilização da metodologia no processo de projeto em relação ao total de alunos. 
Outro resultado importante para essa pesquisa mostra que a principal fonte de pesquisa indicada pela maioria dos entrevistados (104 alunos - 85,2\%) foi a internet [Tabela 3]. Já os livros e revistas foram indicados como principal fonte de pesquisa por apenas 23 alunos (18,85\%). Isso mostra a influência da internet no processo projetual e ao mesmo tempo a restrita abrangência de fontes de pesquisa. A pesquisa de campo, muito importante para avaliar "o todo" em um produto, ou seja, aspectos de uso e outras percepções que não são possíveis através do computador, parece que está sendo deixada de lado.

\begin{tabular}{|c|c|c|}
\hline \multicolumn{3}{|c|}{ Principal fonte de pesquisa } \\
\hline & $\mathrm{N}^{\circ}$ de alunos & $\%$ de alunos \\
\hline Internet & 104 & $85,2 \%$ \\
\hline Livros/Revistas & 23 & $18,85 \%$ \\
\hline
\end{tabular}

Tabela 3.

Principal fonte

de pesquisa.
Ao analisar os dados percebeu-se que grande parte das hipóteses apresentadas foram confirmadas e, mesmo aquelas que não foram confirmadas inicialmente, quando analisadas com mais profundidade, indicaram respostas muito próximas às hipóteses levantadas. Mas independente de se aproximarem ou não das hipóteses, os resultados indicam, de forma geral, que existem falhas na adequação aos processos pois muitas vezes não se utilizam dessas técnicas "tradicionais" e quando usam, a princípio, não exploram muito, ou seja, parece que não há muito compromisso em torno da investigação sobre o problema, tanto em relação ao uso da metodologia, quanto em relação ao uso do desenho expressional ou em relação às fontes pesquisadas.

Com esses resultados, entende-se que o problema não se fecha, mas pelo contrario, amplia o leque de possibilidades de investigação e discussão em torno do tema pesquisado, que se mostrou bastante pertinente. Do mesmo modo que aqui só foram apresentados e analisados alguns dos resultados possíveis a partir do formulário utilizado, acredita-se que esses dados possam ser analisados sob outros pontos de vista, trazendo contribuições além do que foi proposto como objetivo dessa pesquisa. 


\section{Considerações finais}




\section{Considerações finais}

O levantamento bibliográfico realizado para essa pesquisa possibilitou a constatação e o esclarecimento de alguns aspectos muito pertinentes à atividade do design. Primeiro que uma das características mais marcantes que deram origem à essa profissão foi a necessidade de inserção do projeto, em virtude do aumento brutal da escala de produção, que dificultava o ajuste ou correção no meio do processo, por isso é possível afirmar que design é uma atividade essencialmente de projeto. Segundo que o projeto baseia-se em um processo intitulado metodologia de projeto, que serve principalmente para organizar a criação.

A evolução das metodologias e os recentes estudos sobre os processos criativos mostram que existe um tempo de processamento que é fundamental para a ação projetual. Ao mesmo tempo que as metodologias orientam o processo, mostram que mitos cada vez mais em evidência (como a genialidade e o talento profissional) dependem do nível de transpiração, disciplina e adequação aos processos, assim como Leonardo da Vinci, que dedicava valioso tempo em estudos e planejamentos para suas obras, é considerado um gênio na atualidade. Não há como negar, portanto, que grande parte dessa genialidade deve-se à sua dedicação ao estudo e investigação no desenvolvimento de seus projetos. 
Em nossa atual sociedade ansiosa, que cultiva os resultados imediatos, os processos projetuais, extremamente fundamentais para o ensino, ficam em segundo plano. Isso se reflete hoje, no mercado profissional, naquelas pessoas que fazem cursos rápidos em busca de resultados imediatos, sem se apoiar na teoria, que é base da maioria dos softwares disponíveis na área, desenvolvendo seus projetos através de tentativa e erro.

Ao desenvolver o embasamento teórico sobre a história do design e suas metodologias percebeu-se que a ênfase é dada ao design de produto, mas a natureza da comunicação visual tem origens na tipografia, fase muito anterior à Bauhaus. Apesar dessa diferença significativa, o processo criativo é muito semelhante em ambas as àreas, por isso a abordagem dos processos não foi alterada. Quando a tecnologia ainda era pouco avançada, criar algo novo era bastante complicado, a começar pelos custos de produção. $\mathrm{O}$ avanço das tecnologias e as mudanças na escala de produção ampliaram em muito as possibilidades de criação e, justamente, devido a infinidade de possibilidades possíveis, o apoio aos processos já existentes, ainda que tradicionais, tornam-se mais fundamentais ainda. Para uns a adequação ao processo parece ser metódica, retrógrada, conservadora. Através do que se observou até aqui ocorre o contrário, a adequação amadurece a criação. O cumprimento de etapas traduz a seriedade com que o projeto é desenvolvido e sua complexidade é que vai definir a profundidade com que cada etapa será desenvolvida.
Já que a atividade projetual exige organização, é preciso conhecer e classificar os processos criativos, como forma de entendê-los e avaliá-los. Contudo, existe uma imprecisão de linguagem nas terminologias que classificam os tipos de desenhos utilizados no processo que atrapalham o seu entendimento. Se a evolução de uma sociedade depende também da qualidade de sua comunicação, em representação gráfica existe a necessidade urgente de melhorar a comunicação para se explorar os benefícios que o desenho propicia no ato criativo. Diante da imprecisão de linguagem, adotou-se o termo desenho expressional, sugerido por Medeiros (2004), como a melhor forma de representar os desenhos preliminares utilizados na concepção de ideias durante a atividade projetual.

À medida que o processo criativo é entendido e classificado, ele se torna mais palpável e portanto, mais fácil de ser avaliado e mensurado, dando base e credibilidade à área da criação. Medeiros (2004) lembra que somente o conhecimento codificado pode ser adequadamente gerenciado e, por se tratar de projetos de produtos industriais e a trabalhos em equipe, os aspectos de gestão do conhecimento não são apenas pertinentes, eles são decisivos. A classificação de Gomes et. al. (2009) pode ser um grande avanço no gerenciamento e consequentemente ensino desse processo criativo e, por que não, para questões de credibilidade, respeito, valorização ou até mesmo para a regulamentação nas profissões que lidam com a atividade de projetar graficamente. 
No início desta pesquisa, acreditava-se que o desenho expressional funcionava como um "carro chefe" dentro do projeto, norteando a criação, mas ao contrário, o que ficou claro é que existem etapas dentro de um projeto, que são muito importantes para o seu desenvolvimento e que o desenho expressional não é uma etapa, mas sim um recurso de apoio ao processo de projeto, auxiliando em várias fases, principalmente nas preliminares, pois também depende de alguns fatores, como a pesquisa e definição do problema, para que seja conduzida de maneira produtiva.

O uso do desenho expressional reflete, em partes, o compromisso com que o projeto é conduzido devido ao interesse pela investigação à procura de uma solução. Sua utilização não quer dizer necessariamente que o projeto vai ficar melhor, ele é um agente facilitador para o desenvolvimento projetual, contudo depende de habilidade gráfica e conhecimentos para ser executado. Além disso, se o projetista não souber julgar ou interpretar os desenhos que fez, ele só vai produzir mais informações e não amadurecerá a ideia e o aumento do número de alternativas pode até atrapalhar se ele não souber o que fazer com elas. Por isso, além de realizar os desenhos, é preciso saber interpretá-los e classificá-los para que contribuam de forma efetiva.
O desenho expressional têm sido alvo de recentes pesquisas devido à inserção dos computadores no processo de projeto. Essas pesquisas apontam que a habilidade e domínio sobre a ferramenta é fator crucial para que contribua de forma efetiva à função ao qual foi atribuída.

De acordo com os levantamentos bibliográficos e da pesquisa de campo realizada pode-se afirmar que o desenhoexpressional é um recurso muito importante de apoio ao processo criativo pois:

- Favorece uma melhor compreensão do problema projetual (CARVALHO et al, 2005);

- Amplia as possibilidades de solução;

- Envolve transformações que evidenciam o nível de processamento da ideia;

- Revela a incerteza e dúvida do processo decisório e expõe as dificuldades enfrentadas (FLORIO, 2008);

- Transcorre melhor à mão livre do que no computador (NAKATA, 2003);

- Pode proporcionar soluções mais maduras ao ponto que tolera o adiamento de decisões (MEDEIROS, 2004);

Entre os resultados mais expressivos da presente pesquisa de campo evidencia-se a utilização do desenho expressional como um dos fatores que mais influenciaram na dificuldade que os alunos tiveram ao desenvolver seus projetos, fator que amplia o espaço para futuras investigações mais aprofundadas. 
Grande parte dos registros de desenhos de expressão divulgados em diversos tipos de mídias referem-se a desenhos já mais delineados, refinados, mais resolvidos, e portanto não revelam tanto do processo criativo pelo qual o criador passou. Porém, cultivar o resultado é mostrar a resposta. Em se tratando de ensino, isso é fatal. No ensino os processos é que devem ser valorizados, os desenhos iniciais, as dificuldades, os erros e acertos. Deveria-se ensinar a lidar com as dificuldades no início do processo e mostrar que não existe certo ou errado, mas transformações que ocorrem quando se desenha, que dependem de muita transpiração e contribuem mais ou menos à atividade projetual.

A utilização dos "cadernos de rascunho" ou blocos de anotações não pautados são ótimas alternativas que os professores de disciplinas projetuais poderiam adotar com seus alunos como material básico de disciplina para se cultivar os desenhos de expressão, criando-se o hábito de deixar as idéias fluirem naturalmente, sem qualquer pretensão de julgamento, apenas como forma de extrair e explorar, de forma gráfica, as idéias que se apresentam, espontâneas ou não e, já que a hipótese de que este tipo de desenho desempenha um papel importante no processo de projeto foi confirmada, sugere-se a inclusão de disciplinas voltadas para o ensino e a exploração dos desenhos de expressão nos cursos superiores que envolvem o projetar graficamente.
Hoje ainda existem produtos industrializados de baixa qualidade, a preços acessíveis e produtos industrializados de alta qualidade, a preços exorbitantes. Na maioria das vezes essa segunda condição é imposta pela indústria que sabe o valor que o design exerce sobre o seu produto. Por isso, se o compromisso de investigação sobre o problema projetual não for estimulado no ensino, perpetua-se as duas condições citadas acima, que são contrárias aos ideais de William Morris. Neste caso a qualidade do design ficaria a critério das empresas e não dos designers. Para a formação de profissionais em design conscientes e responsáveis por sua atuação, a valorização do poder de investigação que é proporcionado pelo desenho expressional pode ser um caminho bastante promissor. 


\section{Bibliografia}

consultada e referenciada 
ADG, Associação dos Designers Gráficos.

ABC da ADG: Glossário de termos e verbetes utilizados em Design Gráfico.

São Paulo: ADG, [s.d.]

ALMEIDA, Álvaro José Paiva de.

O papel do desenho na prática de projeto.

Anais do $18^{\circ}$ Simpósio Nacional de Geometria Descritiva e

Desenho Técnico e VII International Conference on Graphics

Engineering for Arts and Design - Graphica 2007.

Curitiba: UFPR, 2007.

ALMEIDA, Heleno.

\section{Metodologia e Criatividade.}

[s.l.: s.e., s. d.]

Disponivel em <http://www.helenoalmeida.com/6.html>.

Acesso em: 13/05/2009, 23:26.

ANDRADE, Maria Margarida de.

Como preparar trabalhos para cursos de pós-

graduação: noções praticas. 6 ed

São Paulo: Atlas, 2004

ANTUNES, Ricardo.

Guia do llustrador.

[s.l., s.e., s.d.]

Disponivel em <http://www.guiadoilustrador.com.br/guia.html>.

Acesso em: 13/07/2009, 11:10.

BRASIL, Secretaria de Educação Fundamental.

Parâmetros curriculares nacionais: arte.

Brasilia: MEC/SEF, 1997.

BARBOSA JÚNIOR, Alberto Lucena.

Arte da animação: técnica e estética através da história.

São Paulo: Senac SP, 2002.

CARDOSO, Rafael.

Uma Introdução à historia do design. 3 ed.

São Paulo: Blucher, 2008

CARVALHO, Gisele Lopes; DANTAS, Ney; MEDEIROS, Cleide Farias de. A cognição na projetação: computador versus

lápis na concepção arquitetônica.

Anais do $17^{\circ}$ Simpósio Nacional de Geometria Descritiva e

Desenho Técnico e VI International Conference on Graphics

Engineering for Arts and Design - Graphica 2005

Recife: UFPE, 2005
CASTILLO, Leonardo.

Métodos de Design.

[s.l.: s.e.], 2008

Disponivel em <http://www.scribd.com/doc/8251822/metodos-de-design>

Acessso em: 13/05/2009, 23:15

\section{COMPUTER ARTS.}

Baú de ideias.

São Paulo: Europa, no 24, ano 2, ago/2009.

DEGANI, José Lourenço.

O desenho expressional como fundamento para

projeto em desenho industrial / design.

Anais do $19^{\circ}$ Simpósio Nacional de Geometria Descritiva e

Desenho Técnico e VIII International Conference on Graphics

Engineering for Arts and Design - Graphica 2009.

Bauru: UNESP, 2009

DE MASI, Domenico.

O Ócio Criativo.

Rio de Janeiro: Sextante, 2000

DEMPSEY, Amy.

Estilos, escolas e movimentos.

São Paulo: Cosac Naify, 2003

DINIZ, Luciana Nemer.

Pensamento visual $x$ pensamento gráfico.

Anais do $18^{\circ}$ Simpósio Nacional de Geometria Descritiva e

Desenho Técnico e VII International Conference on Graphics

Engineering for Arts and Design - Graphica 2007.

Curitiba: UFPR, 2007

EDWARDS, Betty

Desenhando com o lado direito do cérebro.

Rio de Janeiro: Tecnoprint, 1984.

ESCOREL, Ana Luisa.

$O$ efeito multiplicador do design.

São Paulo: Senac, 2000

FARIAS, Priscila L.

Tipografia digital: o impacto das novas tecnologias. 1. ed.

Rio de Janeiro: $2 A B, 1998$ 
FLORIO, Wilson.

Experimentação e Incerteza no Processo de Projeto: uma reflexão sobre o papel dos croquis de concepção em Arquitetura.

Anais do $8^{\circ}$ Congresso Brasileiro de Pesquisa e

Desenvolvimento em Design, P\&D Design 2008.

São Paulo: AEND Brasil, 2008.

FOLHA DE SÃO PAULO [coordenação e organização].

Leonardo da Vinci. Coleção Folha Grandes Mestres da Pintura, volume 3.

Barueri: Editorial Sol go, 2007.

FRISONI, Bianka Cappucci; RODRIGUES, Renato Buchele.

A importância da pesquisa no processo metodológico de Design.

Anais do $2^{\circ}$ Congresso Internacional de Pesquisa em Design - CIPED 2003

Rio de Janeiro: 2003

GARDNER, Bill; FISHEL, Catharine. [organizadores].

LogoLounge 2: 2.00o international indentities by leading designers.

Massachusetts: Rockport Publishers, [s.d.]

GOMES. Luiz Vidal Negreiros Gomes.

Desenhismo.

Santa Maria: UFSM, 1996.

GOMES, Luiz Antonio Vidal de Negreiros; MEDEIROS,

Ligia Maria Sampaio de; JUNIOR, Marcos Brod.

Renascimento de fênices: expressão gráfico-projetual na educação.

Anais do $19^{\circ}$ Simpósio Nacional de Geometria Descritiva

Desenho Técnico e VIII International Conference on Graphics

Engineering for Arts and Design - Graphica 2009.

Bauru: UNESP, 2009.

GÓMEZ, Luiz Salomão Ribas; VIEIRA, Milton Luiz Horn

PEREIRA, Clauciane Vivian; DICKIE, Isadora Burmeister.

A coleta de informação como alicerce na

metodologia projetual de design gráfico.

Anais do $8^{\circ}$ Congresso Brasileiro de Pesquisa e

Desenvolvimento em Design, P\&D Design 2008.

São Paulo: AEND Brasil, 2008.

GOSWAMI, Amit.

A janela visionária: um guia para a iluminação por um físico quântico.

São Paulo: Cultrix, 2006

HENDEL, Richard.

O Design do Livro.

São Paulo: Ateliê Editorial, 2003.
HERRERA2_04_BIG.JPG.

[s.d.]

Altura: 1050 pixels. Largura: 1400 pixels. 72 dpi. 8

BIT RGB. 392 Kb. Formato JPEG bitmap.

Disponivel em: <http://homepage.mac.com

deepfriedcandy/ herrera2_04_big.jpg>.

Acesso em: 20/10/2009, 11:09.

HOUAISS, Antonio.

Dicionário eletrônico HOUAISS da lingua portuguesa. V.1.

[s.l.]: Editora Objetiva Ltda, 2001

ICSID - International Council of Sosieties of Industrial Design.

Definition of Design.

[s.l., s.e, s.d.]

Disponivel em <http://www.icsid.org/about/about/articles31.htm>

Acesso em: 27/05/09, 00:10.

JERVIS, Simon.

The Penguin Dictionary of Design and Designers.

Londres: Penguin Books, 1984

JUNIOR, Aarão Pereira de Araújo; RÊGO, Rogéria Gaudêncio.

Desenvolvendo a habilidade do esboço no curso

de design de interiores do CEFET-PB.

Anais do $17^{\circ}$ Simpósio Nacional de Geometria Descritiva e

Desenho Técnico e VI International Conference on Graphics

Engineering for Arts and Design - Graphica 2005.

Recife: UFPE, 2005.

JUSTER, Norton.

Tudo depende de como você vê as coisas.

São Paulo: Companhia das Letras, 1999.

LÖBACH, Bernd.

Design Industrial: bases para o planejamento de produtos industriais.

São Paulo: Blucher, 2001.

LOUW, Warren.

WIP 1 - NOT QUITE.jpg.

2009a.

Altura: 3362 pixels. Largura: 2854 pixels. 300 dpi. 8

BIT RGB. 1,3 Mb. Formato JPEG bitmap.

Disponível em <http://www.imaginefx.com/-2287754332939618735/

Downloads.html. ><files.zip ><UNI49.tut_louw>.

Acesso em: 28/10/2009, 18:26. 
LOUW, Warren.

WIP 2 - NAILED IT!.jpg

$200 \mathrm{gb}$.

Altura: 3362 pixels. Largura: 2854 pixels. 300 dpi. 8

BIT RGB. 1,3 Mb. Formato JPEG bitmap.

Disponivel em <http://www.imaginefx.com/-2287754332939618735/

Downloads.html. $><$ files.zip $><U N 149$.tut_louw $>$.

Acesso em: 28/10/2009, 18:26

\section{LOUW, Warren.}

\section{WIP 6 - ALMOST THERE!.jpg.}

2009c.

Altura: 3362 pixels. Largura: 2854 pixels. 300 dpi. 8

BIT RGB. 3,8 Mb. Formato JPEG bitmap.

Disponivel em <http://www.imaginefx.com/ - 2287754332939618735/

Downloads.html $><$ files.zip $><$ UNI49.tut_louw $>$.

Acesso em: 28/10/2009, 18:26

\section{LUPTON, Ellen.}

Pensar com tipos: guia para designers, escritores, editores e estudantes. São Paulo: Cosac Naify, 2006

\section{MACACOLANDIA.}

126.JPG

[s.d.]

Altura: 425 pixels. Largura: 1019 pixels. 72 dpi. 8 BIT

RGB. 128 Kb. Formato JPEG bitmap.

Disponivel em: <http://www.macacolandia.com.br/v2/ oo_downloads/126.jp>. Acesso em: 20/10/2009, 11:23.

\section{MARTINO, Jarryer Andrade de.}

A importância do croqui diante das novas tecnologias no processo criativo. Dissertação de mestrado. Faculdade de Arquitetura, Artes e Comunicação

da Universidade Estadual Paulista "Júlio de Mesquita Filho" - UNESP.

Bauru, UNESP, 2007.

MARTINO, Jarryer Andrade de.

O Croqui como representação gráfica do processoCriativo.

Anais do $8^{\circ}$ Congresso Brasileiro de Pesquisa e

Desenvolvimento em Design - P\&D Design 2008.

São Paulo: AEND Brasil, 2008.

MEDEIROS, Ligia Maria Sampaio de.

O desenho como suporte cognitivo nas etapas preliminares do projeto.

Tese de doutorado. Universidade Federal do Rio de Janeiro - UFRJ.

Rio de Janeiro: COPPE/UFRJ, 2002.
MEDEIROS, Ligia Maria Sampaio de.

Desenhistica: a ciência da arte de projetar desenhando.

Santa Maria: sCHDs, 2004

MEDEIROS, Ligia Maria Sampaio de; GOMES, Luiz Vidal Negreiros.

Desenvolvimento da Linguagem do Desenho: fases, etapas, estágios e níveis. Anais do $3^{\circ}$ Congresso Internacional de Pesquisa em Design - CIPED 2005. Rio de Janeiro: 2005

MELO, Chico Homem de [organização e textos].

Design gráfico caso a caso: como o designer faz design.

São Paulo: ADG, 2000.

MEGGS, Philip B.

História do design gráfico.

São Paulo: Cosac Naify, 2009.

MONTENEGRO, Gildo.

Desenho de Projetos.

São Paulo: Blücher, 2007.

\section{MUNARI, Bruno.}

Das coisas nascem coisas.

Lisboa: Edições 70, 1981.

NAKATA, Milton Koji.

A ilustração não-digital e a ilustração digital: um estudo das

etapas da produção para otimizaçãão da comunicação.

Tese de doutorado. Universidade Estadual Paulista

"Júlio de Mesquita Filho" - UNESP

Bauru: UNESP, 2003

NAKATA, Milton Koji.

Metodologia de Desenho de Observação como

Instrumental para Design Gráfico.

Anais do $8^{\circ}$ Congresso Brasileiro de Pesquisa e

Desenvolvimento em Design - P\&D Design 2008

São Paulo: AEND Brasil, 2008.

NIEMEYER, Oscar [organização]

Museu de Arte Contemporânea de Niterói.

Rio de Janeiro: Revan, 1997.

PANIZZA, Janaina Fuentes Panizza.

Metodologia e processo criativo em projetos de comunicação visual.

Dissertação de mestrado. Escola de Comunicação e

Artes da Universidade de São Paulo - USP.

São Paulo: ECA/USP, 2004 
PEREIRA, Ana Paula de Menezes Pereira; GOMES,

Michelly; FONSECA, Glaucia Augusto.

$O$ croqui e suas técnicas.

Anais do $17^{\circ}$ Simpósio Nacional de Geometria Descritiva e

Desenho Técnico e VI International Conference on Graphics

Engineering for Arts and Design - Graphica 2005

Recife: UFPE, 2005

PERRONE, Rafael Antonio Cunha; LIMA, Ana Gabriela

Godinho; FLORIO, Wilson; QUEIROZ, Cristiane Cavalcanti;

OLIVEIRA, Fausto Pereira de; GIMENES, Graziela Cruz.

Os croquis e os processos de projeto de arquitetura.

Faculdade de Arquitetura e Urbanismo do Instituto Presbiteriano Mackenzie.

[São Paulo: s.e., s.d.]

Disponivel em: <http://www.mackenzie.br/7608 html>.

Acesso em: 28/04/09, 10:03.

RABAÇA, Carlos Alberto; BARBOSA, Gustavo.

Dicionário da Comunicação.

São Paulo: Ática, 1978

RADFAHRER, Luli.

Design/Web/Design.

[s.l.]: Market Press, [s. d.]

RIBEIRO, Milton.

Planejamento visual gráfico. 8 ed.

Brasília: LGE, 2003.

SANTANA, Livia Ferreira.

Projeto e Comunicação: estudo das representações

no contexto do projeto de arquitetura.

Dissertação de mestrado. Universidade Federal do Rio de Janeiro - UFRJ.

Rio de Janeiro: 2002.

STRUNCK, Gilberto.

Rio de Janeiro: 2AB, 1999.

THE PIXAR Story. [Direção de Leslie Iwerks].

[Califórnia]: Disney/Pixar, 2007. DVD.
VERGOTTI, Marco.

617117645_720cb721d9_o.jpg.

2009 .

Altura: 754 pixels. Largura: 1145 pixels. 72 dpi. 8 BIT

RGB. 680 Kb. Formato JPEG bitmap.

Disponivel em: <http://www.flickr.com/photos/

vergotti/3617117645/sizes/o/in/set-72157603968802618/>

Acesso em: 18/10/2009.

VERGOTTI, Marco.

3660050925_07e64a98c1_o.jpg.

$200 \mathrm{gb}$.

Altura: 754 pixels. Largura: 1145 pixels. 72 dpi. 8 BIT

RGB. $200 \mathrm{~Kb}$. Formato JPEG bitmap.

Disponivel em: <http://farm4.static.flickr.com/3332/

3660050925_07e64ag8c1_0.jpg>.

Acesso em: 18/10/2009.

\section{VERGOTTI, Marco.}

3660848720 6b472d4211_o.jpg.

2009c.

Altura: 754 pixels. Largura: 1145 pixels. 72 dpi. 8 BIT

RGB. 420 Kb. Formato JPEG bitmap.

Disponivel em: <http://www.flickr.com/photos/

vergotti/3660848720/sizes/o/in/set-72157603968802618/>

Acesso em: 18/10/2009.

WEBL1237.JPG. [s.d.]

Altura: 285 pixels. Largura: 400 pixels. 72 dpi. 8 BIT

GRAY. 111,3 Kb. Formato JPEG bitmap.

Disponivel em: <http://www.webcine.com.br/filmesc1/webl1237.jpg>

Acesso em: 20/10/2009.

WHEELER, Alina.

Design de identidade da marca. 2 ed.

Porto Alegre: Bookman, 2008.

WIKIPEDIA. Cannes Lions International Advertising Festival. [s.d.]

Disponível em <http://en.wikipedia.org/wiki/Cannes_

Lions_International_Advertising_Festival>.

Acesso em: 03/12/2009, 11:53.

WOLLNER, Alexandre.

Design visual 50 anos.

São Paulo: Cosac \& Naify, 2003

ZÖLLNER, Frank

Leonardo da Vinci: 1452-1519.

Köln:Taschen, 2006. 
Apêndices 
Formulário de pesquisa 
Anexos 


\section{Programa da disciplina \\ Projeto 5-Programação Visual}

\section{Disciplina semestral obrigatória}

Curso: Desenho Industrial - Habilitação em Programação Visual

Unidade: Faculdade de Arquitetura, Artes e Comunicação -

FAAC - UNESP

Departamento responsável: Desenho Industrial

Pré-requisitos: Projeto II - 0007

Termo: $7^{\circ}$

\section{Créditos: 4}

Carga horária total: 60

Código: 0160

\section{Objetivos}

(Ao término da disciplina o aluno deverá ser capaz de:) Assimilar os conceitos de programação visual em diferentes peças de comunicação de massa, trabalhando com os elementos: texto, ilustração, cor e espaço.

\section{Conteúdo programático}

(Título e discriminação das unidades de ensino)

1. PROPAGANDA - Publicidade e Programa; Propaganda no contexto do marketing; Peças publicitárias.

2. ANÚNCIO - Mensagens de propaganda, comerciais, institucionais, políticas, etc. Veículos para anúncios, Anúncios em preto e branco, Anúncios em cor.

3. MALA-DIRETA - Propaganda por via postal, Formatos, Vincos, papéis, etc.; Layout - disposição de elementos gráficos; Arte final - paste-up, ilustrações-fotografia.

4. CATÁLOGO - Criação; Lay-out e arte final

\section{Metodologia do ensino}

Aulas práticas, acompanhadas de teoria, trabalhando com diversas peças de propaganda.

\section{Bibliografia básica}

BARRETO, R.M. Criatividade em Propaganda - Summus

Editorial - SP/1982;

BUCHAN, J. Secretos de estúdio para el artista grafico-

Ed.Hermann Blume - Madrid/1988;

HURLBURT, A. Layout - Ed.Mosaico - SP/1980;

MOLLES, A. O Cartaz - Ed.Perspectiva - SP/1987;

REDIG, J. Sentido do Design - Ed.Imprinta - SP/1983

Manuais de Programas Gráficos - CorelDraw - Adobe

Photoshop-Pagemaker.

\section{Critérios de avaliação da aprendizagem}

$\underline{\mathrm{P}_{1}+\mathrm{P}_{2}} \times 5=\mathrm{MP}$

$\mathrm{T}_{1}+\mathrm{T}_{2}+\mathrm{T}_{3} \times 5=\mathrm{MT}$

$\mathrm{MF}=\mathrm{MP}+\mathrm{MT} / 2$

(MP= Média de Provas, MT= Média de Trabalhos, MF= Média Final)

Ementa (Tópicos que caracterizam as unidades do programa de ensino)

Prática e execução de projetos de Programação Visual.

Composição de imagens para peças de propaganda.

Fonte: Departamento de Desenho Industrial da Faculdade de

Arquitetura, Artes e Comuicação, da UNESP, Bauru, SP 


\section{Programa da disciplina \\ Projeto 5-Projeto do Produto}

Disciplina semestral obrigatória

Curso: Desenho Industrial - Habilitação em Programação Visual

Unidade: Faculdade de Arquitetura, Artes e Comunicação -

\section{FAAC - UNESP}

Departamento responsável: Desenho Industrial

\section{Pré-requisitos:}

Termo: $7^{\circ}$

Créditos: 4 (semestral)

Carga horária total: 60

Código: 1005

\section{Objetivos}

(Ao término da disciplina o aluno deverá ser capaz de:)

Projetar produtos com complexidade mecânica e estrutural, na área de transporte para locomoção humana, considerando a contribuição do Design na área de transporte, naqueles produtos (cuja relação de uso e operação por parte do usuário).

\section{Conteúdo programático}

(Título e discriminação das unidades de ensino)

01.Definição da complexidade do tema do Projeto na área de

Locomoção, e adoção de critérios de avaliação para escolha do produto a ser desenvolvido; considerando os aspectos funcionais, utilitários, estéticos/formais, e os aspectos de fabricação e materiais. 02.Levantamento morfológico das características estruturais e formais do produto que pertencem ao universo do tema do projeto (similares).

03.Exercícios projetuais, que permitam ao aluno envolver-se com o projeto através de etapas sucessivas, identificando soluções já existentes, componentes e sub-sistemas, possiveis de serem empregados em uma proposta de projeto de resenho ou não.

04.Definição das funções do produto, determinando a função básica e as funções secundárias.

05.Análise e verificação ergonômica, não apenas sob o aspecto do conforto (postura), mas também para dimensionamento estrutural/formal.

o6.Projeto e desenvolvimento, por meio de inúmeros esboços, forma de rendering, modelos voluntários, modelos explicativos, desenho detalhados.

07. Critérios de avaliação das propostas envolvidas e desenvolvimento final.

08.Apresentação do projeto, por meio de rendering finais, desenho, modelos ou protótipos, e memorial descritivo. 


\section{Metodologia do ensino}

01.As etapas do projeto mencionadas no cronograma, a fase de definição das funções do produto, e as técnicas de desenho e confecção de modelos, se farão de maneira geral a todos os alunos, independentes se os grupos de projeto desenvolvem produtos iguais ou não.

02.Durante as quatro aulas o aluno desenvolverá exercícios projetuais que caracterizem ao mesmo tempo as etapas de projeto definidas no cronograma.

03.Individualmente ou em grupos formados por 3 ou 4 alunos.

\section{Bibliografia básica}

BONSIEPE, G. Teoria e Práctica del Diseño Industrial.. Barcelona.

Gustavo Gilli. 1978.

BONSIEPE, G. \& WALKER, R. Um Experimento em Projeto

de Produto/Desenho Industrial. Brasília: CNPq/Coordenação

Editorial, 1983.

BONSIEPE, G. et allii. Metodologia Experimental - Desenho

Industrial. Brasília. CNPq/Coordenação Editorial. 1984.

LLOVET. J., Ideologia y Metodologia del Diseño. Barcelona.

Gustavo Gilli, 1981.

LOBACH. B., Disenõ Industrial. Barcelona. Gustavo Gilli, 1981.

\section{Critérios de avaliação da aprendizagem}

Individualmente o aluno será submetido à avaliação a nível de ante-projeto, identificando nessa avaliação o envolvimento do mesmo em relação ao projeto, e sua participação coletiva. A isto será atribuído peso 3.

O Projeto final entregue como trabalho conclusivo do semestre terá peso 7 .

\section{Ementa}

(Tópicos que caracterizam as unidades do programa de ensino)

Prática e execução de Projeto de Produto - equipamentos e

locomoção.

Fonte: Departamento de Desenho Industrial da Faculdade de

Arquitetura, Artes e Comuicação, da UNESP, Bauru, SP 


\section{Programa da disciplina \\ Projeto 6 - Programação Visual}

Disciplina semestral obrigatória

Curso: Desenho Industrial - Habilitação em Programação Visual

Unidade: Faculdade de Arquitetura, Artes e Comunicação-

FAAC - UNESP

Departamento responsável: Desenho Industrial

Pré-requisitos: não tem

Termo: $8^{\circ}$

\section{Créditos: 4}

Carga horária total: 60

Código: 0211

\section{Objetivos}

(Ao término da disciplina o aluno deverá ser capaz de:)

Manipular os conceitos da produção e projeto da publicação desde sua idealização seu desenvolvimento até a preparação para sua reprodução gráfica.

\section{Conteúdo programático}

(Título e discriminação das unidades de ensino)

PROJETO DE UMA REVISTA:

1. Escolha de um tema a ser trabalhado.

1.1. Pesquisa de revista ligadas ao tema

1.2. Verificação de semelhanças e diferenças entre as revistas pesquisadas.

2. Desenvolvimento do projeto

2.1. Escolha do nome

2.2. Desenvolvimento do logotipo.

2.3. Estudo e apresentação de lay outs da página base.

2.4. Estudo e apresentação de lay outs da capa

2.5. Estudo e determinação da tipologia

2.6. Estudo e apresentação de lay outs das seções fixas

2.7. Determinação de padrões da tipologia dos títulos, sub-

títulos, seções, textos, etc.
3. Produção da capa.

3.1. Artefinalização do logotipo.

3.2. Artefinalização dos títulos e demais textos

3.3. Produção da ilustração ou foto.

3.4. Past-up da capa

3.5. Aplicação de overlay com todas as indicações para

reprodução gráfica.

\section{Metodologia do ensino}

Análise de exemplos concretos de publicações afins buscando subsídios para a confecção do projeto, seu desenvolvimento e finalização para reprodução gráfica.

\section{Bibliografia básica}

HULBURT, A. Lay Out : Design da pagina impressa. São Paulo.

Ed. Mosaico. 1980.

RIBEIRO, M. Planejamento visual gráfico. Brasilia, Sóbrindes

Editora. 1987.

GREIG, J. Produção gráfica. São Paulo. Editora Mosaico,

Editora da universidade de S.P. 1980.

GERMANI, FABRIS. Fundamentos del projeto gráfico.

Barcelona, Ediciones Don Bosco, 1973.

\section{Critérios de avaliação da aprendizagem}

A avaliação será exemplos individual pela concretização das

etapas do projeto e sua apresentação final.

\section{Ementa}

(Tópicos que caracterizam as unidades do programa de ensino) Prática e execução das várias etapas da projetuação do tema proposto e sua problemática frente aos sistemas de reprodução gráfica.

Fonte: Departamento de Desenho Industrial da Faculdade de Arquitetura, Artes e Comuicação, da UNESP, Bauru, SP 


\section{Programa da disciplina \\ Projeto 6 - Projeto do Produto}

\section{Disciplina semestral obrigatória}

Curso: Desenho Industrial - Habilitação em Projeto do Produto

Unidade: Faculdade de Arquitetura, Artes e Comunicação -

FAAC - UNESP

Departamento responsável: Desenho Industrial

Pré-requisitos:

Termo: $8^{\circ}$

Créditos: 4 (semestral)

Carga horária total: 60

Código: 1006

\section{Objetivos}

(Ao término da disciplina o aluno deverá ser capaz de:)

O aluno deverá desenvolver e alcançar a capacidade projetiva através da aplicação de métodos projetuais, observando as etapas do projeto, que se concretizará pelo desenvolvimento do tema: "Design da interface homem/equipamentos para a horticultura: projeto e experimentação".

\section{Conteúdo programático}

(Título e discriminação das unidades de ensino)

1.Definição, dentre várias, de um problema ligado à Máquinas

e Implementos Agrícolas, possível de solução, através da abordagem técnico-metodológico de Desenho Industrial.

2. Elaboração de um cronograma à ser tomado por base, no desenvolvimento do projeto, sendo que este deverá conter todas as etapas do projeto e o tempo necessário para a execução das mesmas.

3. Definição das funções necessárias à solução do problema ligado à Máquinas e Implementos Agrícolas, determinando suas funções básicas e secundárias.
4. Levantamento morfológico anacrônico e diacrônico de uma gama de produtos que cumpram as funções em questão, bem como a análise destes dados coletados.

5. Definição do projeto à ser executado, através da adoção de critérios de avaliação considerando os aspectos de complexidade, mercado, utilitários, estético/formais e de fabricação/materiais.

6. Exercícios projetuais, que permitam ao aluno envolver-se com o projeto, através de etapas sucessivas, identificando soluções já existentes, os componentes e sub-sistemas possíveis de serem empregados em uma proposta de projeto, podendo este ser redesenho ou não.

7. Análise e verificação ergonômica do projeto em

desenvolvimento, sob os aspectos do conforto dimensionamento estrutural e formal.

8. Utilização da expressão gráfica - desenvolvimento do projeto através de vários esboços, renderings (ilustração), modelos volumétricos, modelos explicativos, modelos virtuais, desenhos detalhados, desenhos técnicos e etc.

9. Definição dos critérios de avaliação a serem considerados no produto e que satisfaçam as funções definidas nas etapas da representação gráfica.

10. Apresentação final do projeto, sob a forma de relatório final memorial descritivo, renderings, modelos e/ou protótipos, fotografias, desenhos técnicos e detalhes do produto. 


\section{Metodologia do ensino}

Durante as 04 (quatro) horas/aulas semanais, o aluno desenvolverá seu projeto, baseado no cronograma proposto

com suas fases definidas previamente definição do projeto,

pesquisa morfológica, desenvolvimento e execução de esboços, renderings, modelos e/ou protótipos, bem como memorial descritivo. Será proposto exercício pertinente a cada fase do projeto: "Máquinas e Implementos Agrícolas".

\section{Bibliografia básica}

-BONSIEPE, Gui - Teoria y práctica del disenõ, Barcelona.

Gustavo Gilli, l978

-LLOVET, Jord - Ideologia y metodologia del disenõ. Barcelona.

Gustavo Gilli, 1981

-MAYALL, W. - Industrial design for engineers. Londosn.

London Ilife Books, 1967.

MINISTÉRIO DA CIÊNCIA E TÉCNOLOGIA - Design de

maquinas especiais. Brasilia. CNPq, 1986.

- Estrutura e estética do produto. Brasilia. CNPq, 1986

\section{Critérios de avaliação da aprendizagem}

O aluno será avaliado individualmente nas etapas de anteprojeto, onde procurará identificar o rel desenvolvimento do mesmo, para tanto atribuirá peso 4 (quatro) para esta fase . Na entrega do relatório final de conclusão, atribuirá peso 6 (seis).

Ementa (Tópicos que caracterizam as unidades do programa de ensino)

- Prática e execução de Projeto de Produto - projeto de máquinas e instrumentos agrícolas.
Fonte: Departamento de Desenho Industrial da Faculdade de Arquitetura, Artes e Comuicação, da UNESP, Bauru, SP 


\section{Processo de concepção de Oscar Niemeyer para o Museu de Arte Contemporânea de Niterói-RJ}

"Às vezes um projeto custa a se definir. Outras, ele surge de repente como se, antes, nele nos tivéssemos detido cuidadosamente.

$E$ isso aconteceu com esse projeto. $O$ terreno era estreito, cercado pelo mar e a solução aconteceu naturalmente, tendo como ponto de partida o apoio central inevitável.

Dele, a arquitetura decorreu espontânea como uma flor.

A vista para o mar era belíssima e cabia aproveitá-la. E suspendi o edifício e sob ele o panorama se estendeu mais rico ainda.

Defini então o perfil do museu. Uma linha que nasce do chão e sem interrupção cresce e se desdobra, sensual, até a cobertura.

A forma do prédio, que sempre imaginei circular, se fixou e, no seu interior, me detive apaixonado.

À volta do museu criei uma galeria aberta para o mar, repetindo-a no segundo pavimento, como um mezanino debruçado sobre o grande salão de exposições.

E me preocupei com os interiores, desejoso que fossem bonitos e variados, convidando os visitantes para conhecê-los melhor.

No terreno, minha idéia foi acentuar a entrada do museu, desenhando a rampa externa. Um passeio ao redor da arquitetura.

E senti que o museu seria bonito e tão diferente dos outros que ricos e pobres teriam prazer em visitá-lo"

(NIEMEYER, 1997, p.15-20).
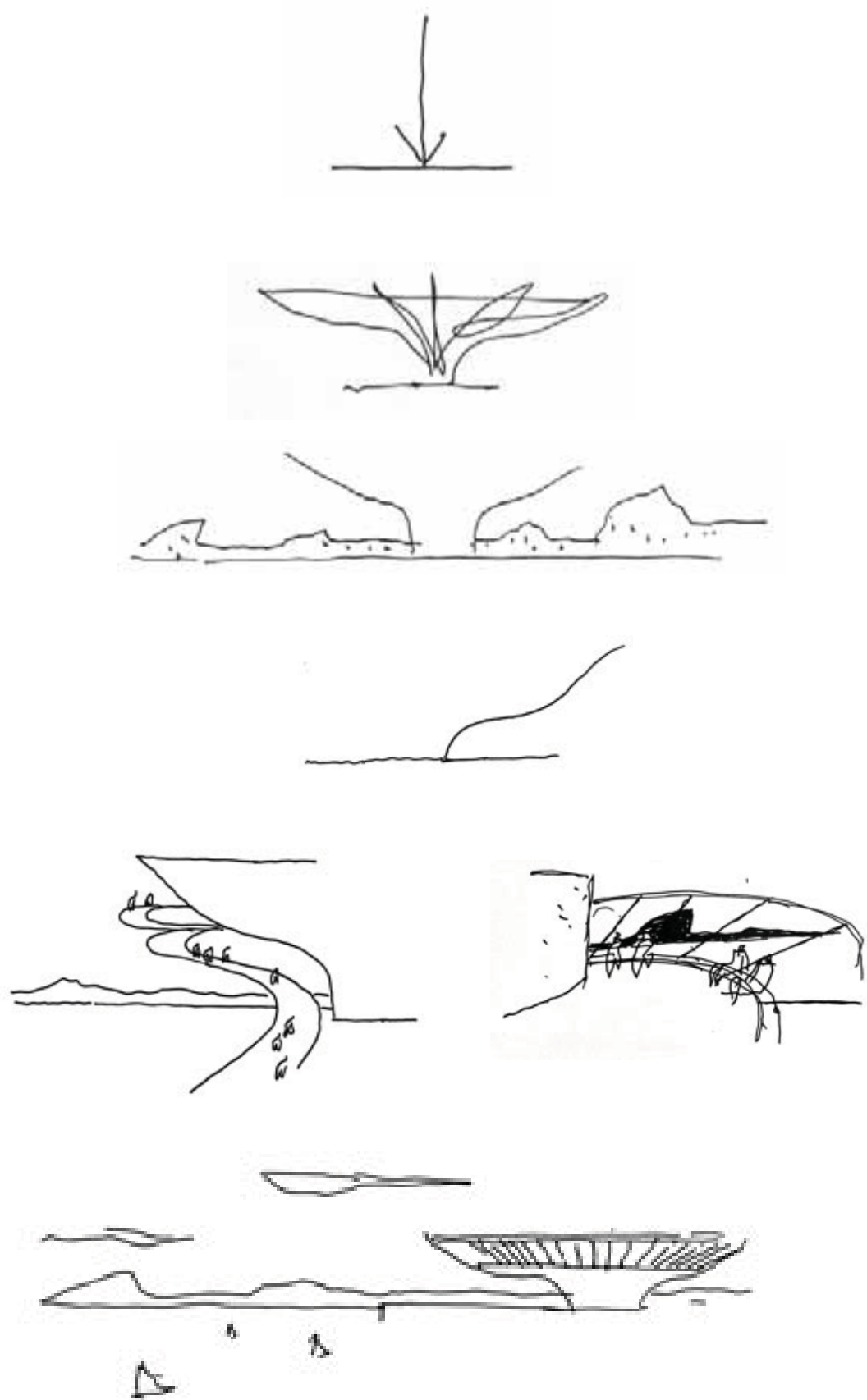


\section{Pixar Process}

Disponível em:

<http://www pixar.com/howwedoit/index html>.

Acesso em: 15/10/2009, 15:35
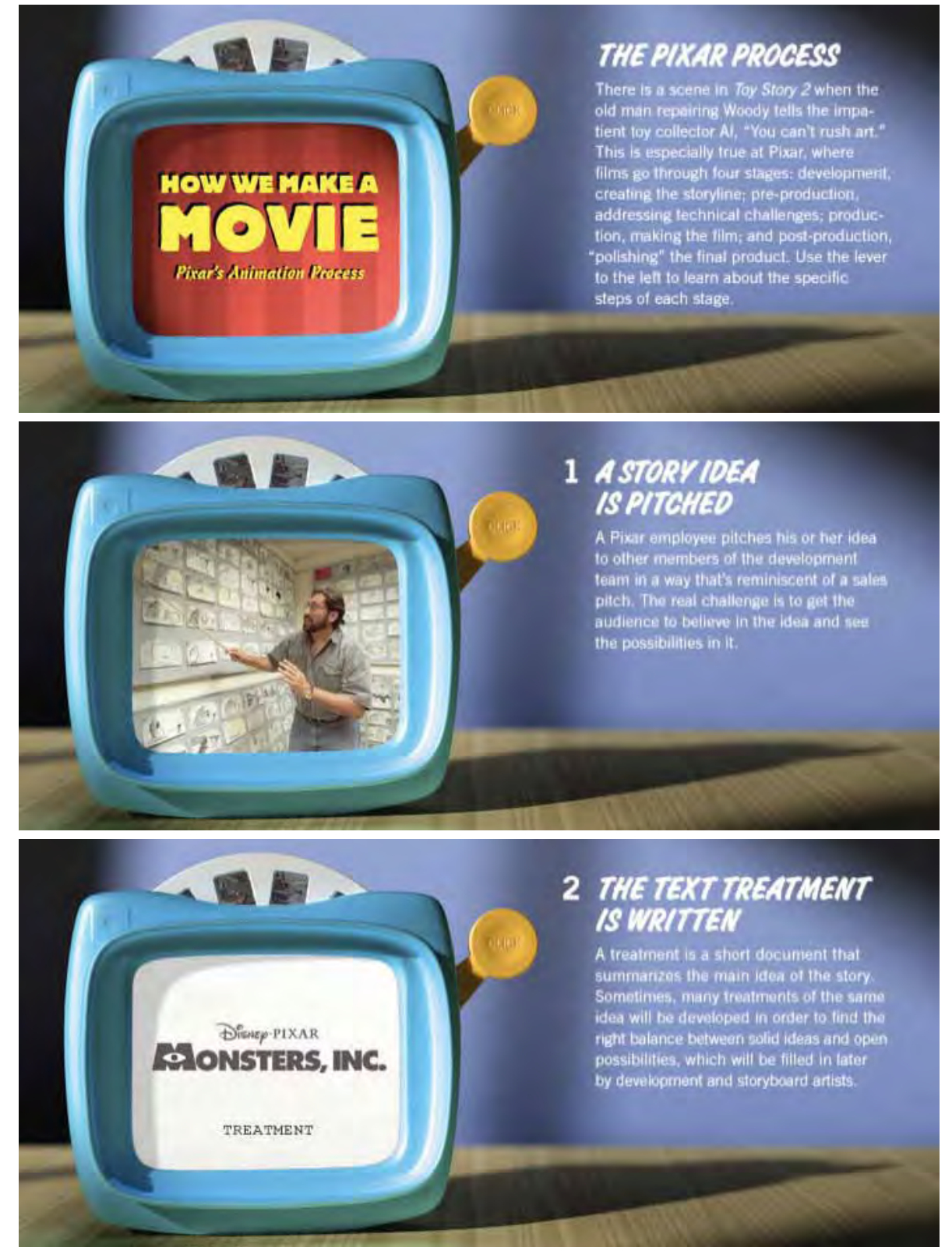


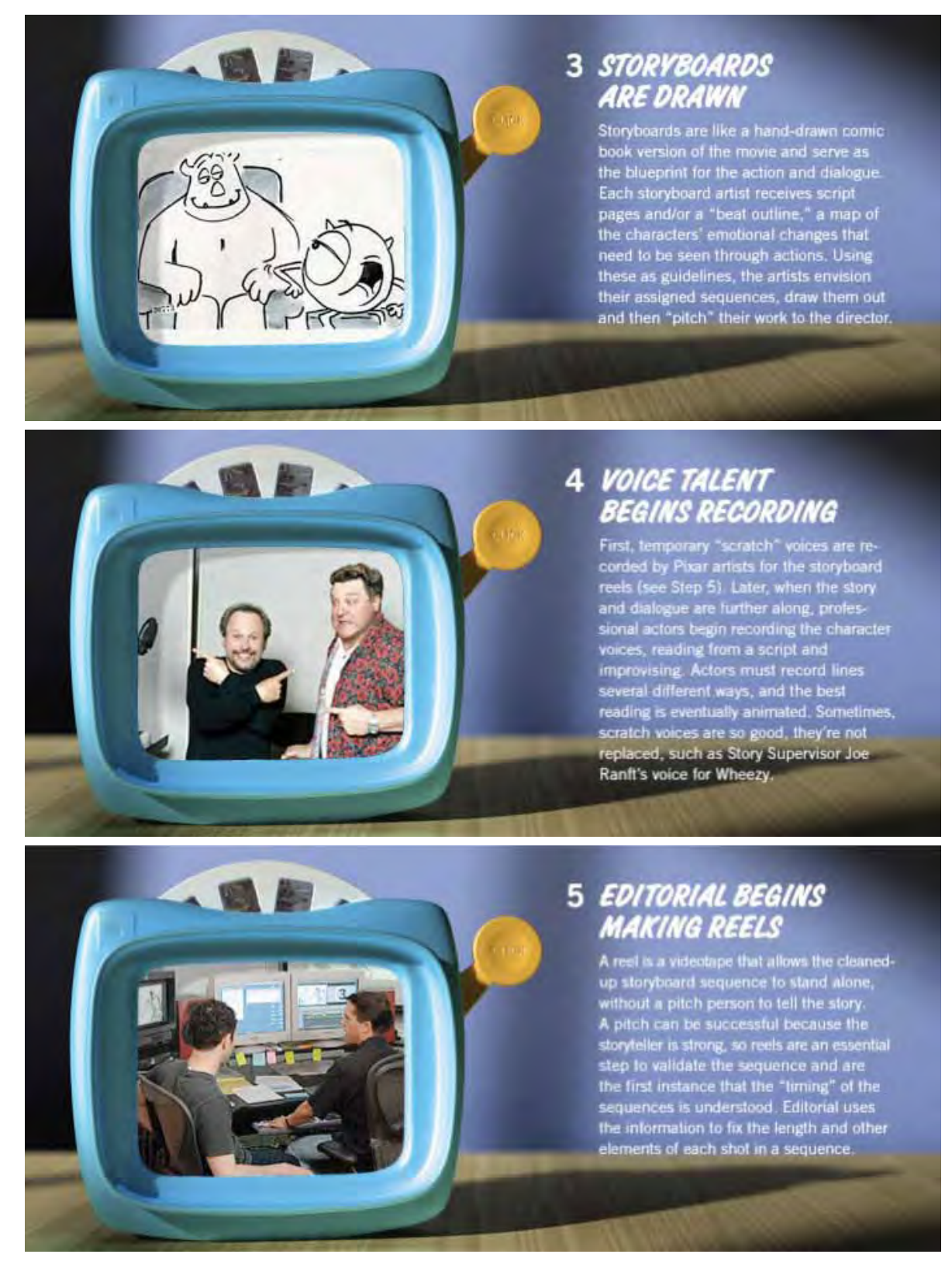




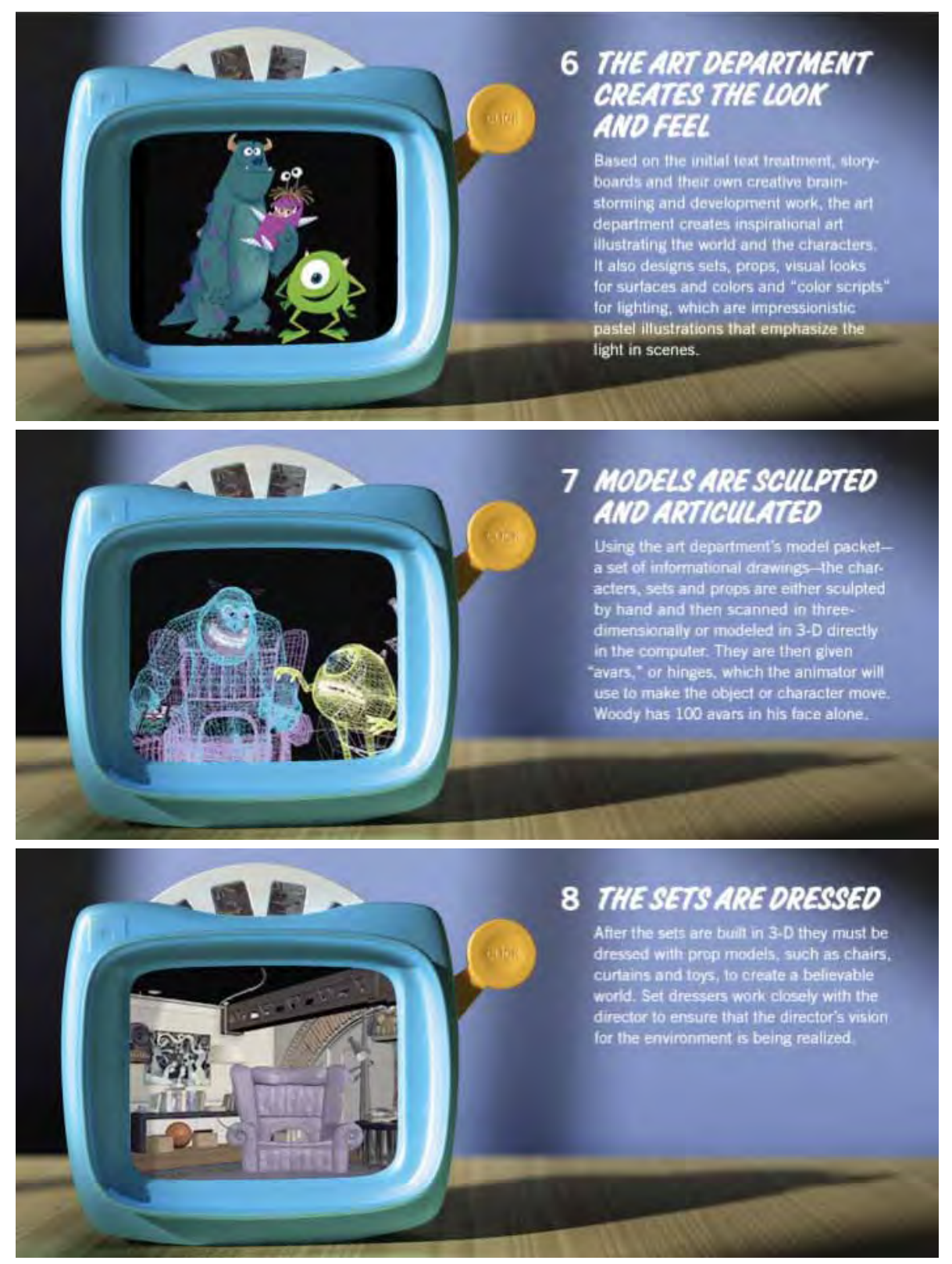



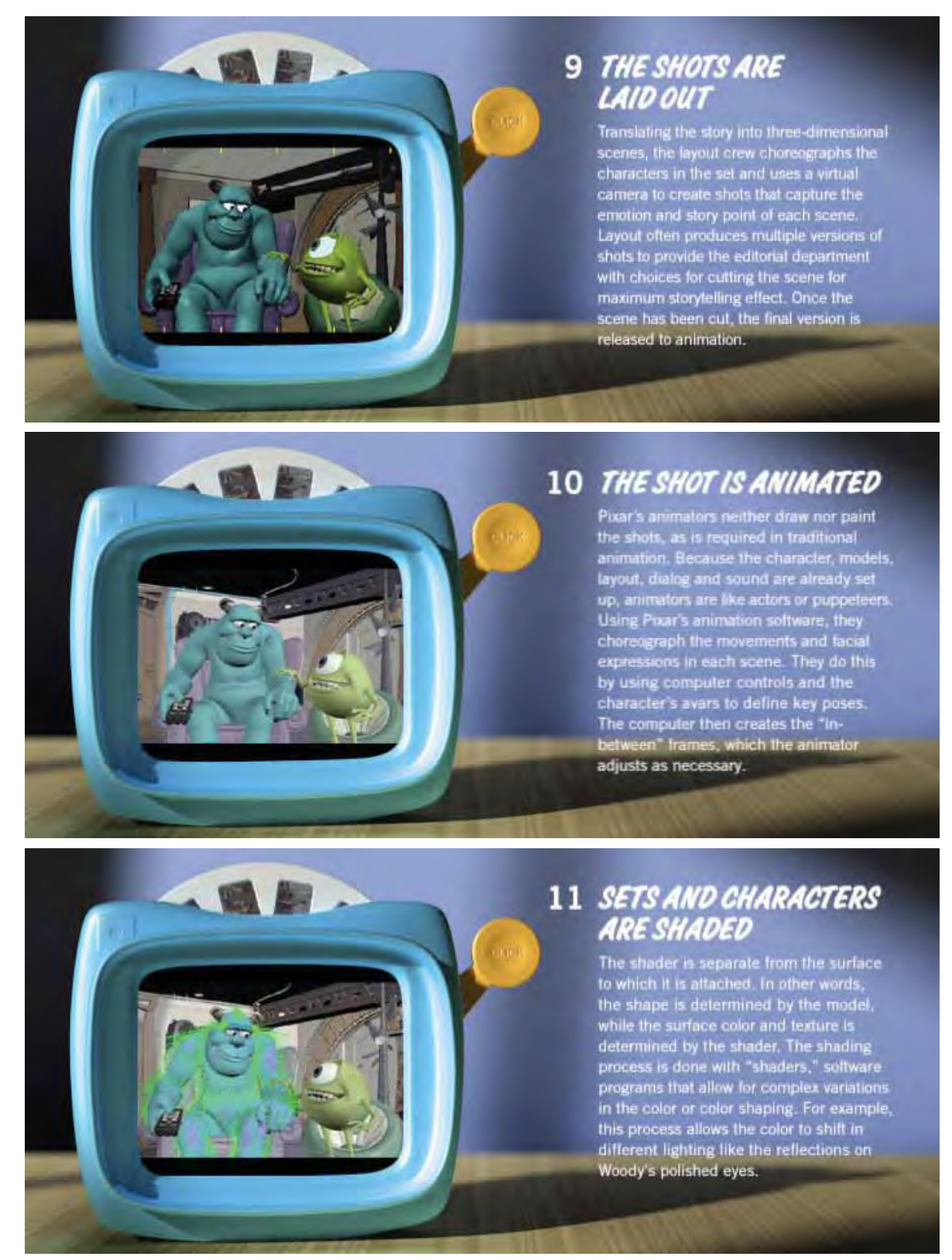

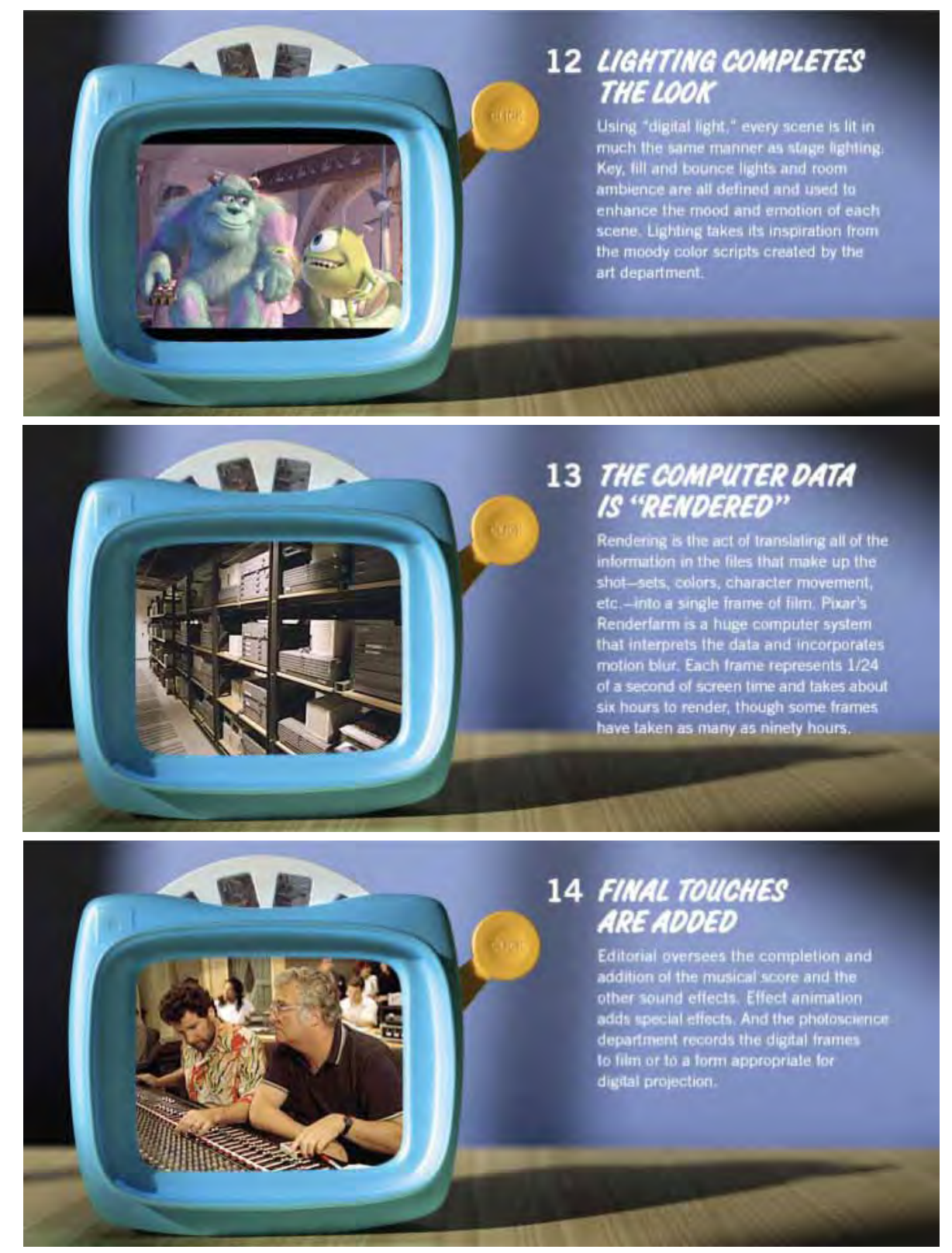